INTER NATIONAL MONETARY FUND
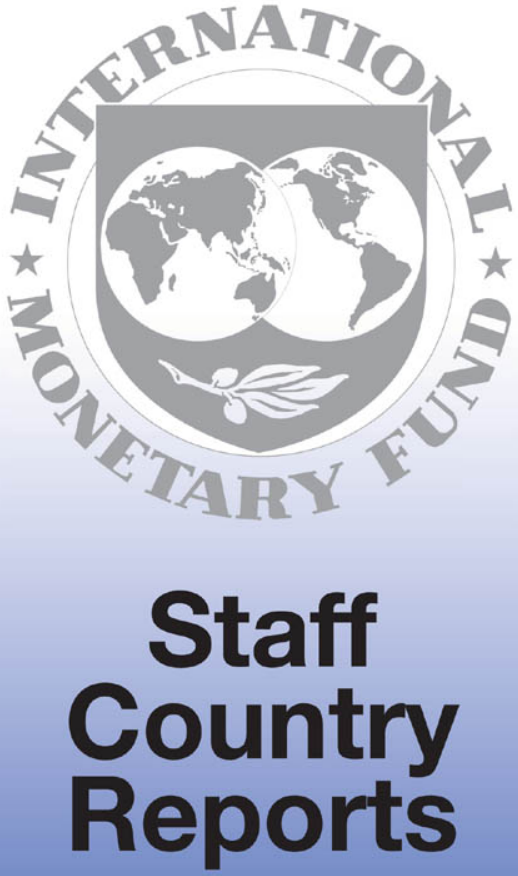


\section{Norway-Recent Economic Developments}

This report on recent economic developments in Norway was prepared by a staff team of the International Monetary Fund as background documentation for the periodic consultation with this member country. In releasing this document for public use, confidential material may have been removed at the request of the member.

Copies of this report are available to the public from International Monetary Fund - Publication Services 700 19th Street, N.W. - Washington, D.C. 20431

Telephone: (202) 623-7430 - Telefax: (202) 623-7201

Telex (RCA): 248331 IMF UR

Internet: pubserv@imf.org

Price: $\$ 15.00$ a copy

International Monetary Fund

Washington, D.C. 
This page intentionally left blank

CInternational Monetary Fund. Not for Redistribution 
INTERNATIONAL MONETARY FUND

NORWAY

\section{Recent Economic Developments \\ Prepared by Birgir Arnason, Ousmane Dore, and Luis Catåo (all EUI) \\ Approved by the European I Department}

January 24, 1995

Contents

Page

Basic Data

iv

I. Overview $\quad 1$

II. Developments in the Real Economy 2

\begin{tabular}{ll}
$1 . \quad$ Background & 2 \\
\hline
\end{tabular}

\begin{tabular}{ll} 
2. Domestic demand & 3 \\
\hline
\end{tabular}

a. Private consumption and household saving 3

b. Public consumption 4

c. Gross fixed investment 4

3. The external current account 5

a. Exports of goods and services 5

b. Imports of goods and services 6

c. The current account balance 7

4. Output

\begin{tabular}{ll}
4. & Prices, wages and competitiveness \\
\hline
\end{tabular}

\begin{tabular}{ll}
\hline 6 . Employment and unemployment & 8 \\
\hline
\end{tabular}

III. Public Finance $r$

1. Background $r$

2. The 1993 state budget and outturn 10

a. Revenue 11

\begin{tabular}{ll}
\hline b. Expenditure & 11 \\
\hline
\end{tabular}

3. The 1994 state budget and outturn 11

a. Revenue 11

b. Expenditure 12

4. The 1995 state budget 12

\begin{tabular}{ll} 
5. General government balances in 1993-94 & 13 \\
\hline
\end{tabular}

6. Military expenditure 14 
IV. Monetary and Exchange Rate Developments and Policy

1. Background

2. Monetary and exchange rate developments 15

a. Exchange rate developments 15

\begin{tabular}{ll}
\hline b. Interest rate developments & 16 \\
\hline
\end{tabular}

c. Developments in the monetary aggregates 16

$\begin{array}{ll}\text { d. Developments in the external reserves } & 17\end{array}$

3. Monetary policy guidelines 17

4. Changes in exchange and trade regulations 18

\begin{tabular}{ll}
\hline . Official development assistance & 19 \\
\hline
\end{tabular}

\section{Appendices}

I. Estimates of the Output Gap and the NAIRU

II. The General Government Structural Balance 1988-95 25

III. The Norwegian Petroleum Sector $r$

IV. The Petroleum Boom and Norway's External Competitiveness 36

V. The Resolution of the Norwegian Banking Crisis 1993-94 46

\section{Tables}

1. Domestic Demand and Output

2. External Current Account

3. Contributions to Growth in 1993 and $1994 \quad 8$

4. State Budget Balance, $1993 \quad 10$

\begin{tabular}{lll}
\hline 5. State Budget Balance, 1994 & 12 \\
\hline
\end{tabular}

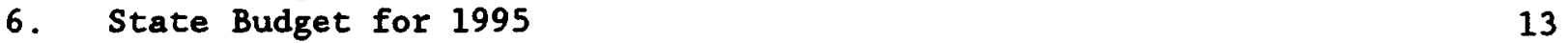

7. State Budget and General Government Balances, 1992-94 14

8. Military Expenditure, 1991-95

\begin{tabular}{ll}
\hline 9. Norway's Official Development Assistance & 19 \\
\hline 10. & 21
\end{tabular}

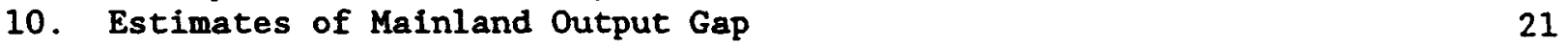

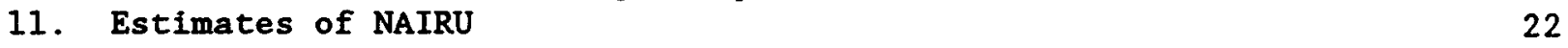

12. Profit and Loss Accounts of Commercial Banks 4

13. Profit and Loss Accounts of Savings Banks (Parent Bank) 49

14. Government Expenses in Connection with the Banking

Crisis at December 31,1993

\section{Charts}

1. Output and Expenditure $2 a$

2. Fixed Investment $2 \mathrm{~b}$

3. External Developments $r$

4. Inflation and Unemployment $r a$

\begin{tabular}{lr}
\hline 5. Public Finance & $10 \mathrm{a}$ \\
\hline
\end{tabular}

6. Interest Rate Developments $16 \mathrm{a}$

7. Exchange Rate Developments $16 \mathrm{~b}$

\begin{tabular}{ll}
\hline 8. Mainland GDP & $26 a$ \\
\hline
\end{tabular}

\begin{tabular}{ll}
\hline 9 . Unemployment & $28 \mathrm{a}$ \\
\hline
\end{tabular} 
10. 011 and Gas Production $30 \mathrm{a}$

11. Petroleum Sector 32 32a

12. Market Share of Traditional Exports 38

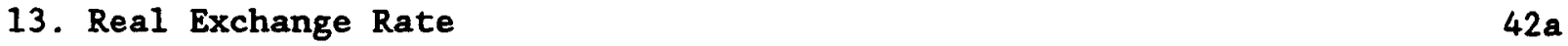

\section{Statistical Appendix}

A1. Demand and Supply 54

\begin{tabular}{lll}
\hline A2. & Private Consumption & 55 \\
\hline
\end{tabular}

A3. Household Income and Saving 56

\begin{tabular}{lll}
\hline $44 . \quad$ Gross Fixed Investment & 57 \\
\hline
\end{tabular}

\begin{tabular}{lll}
\hline A5. Real GDP by Sector & 58 \\
\hline
\end{tabular}

\begin{tabular}{lll}
\hline A6. Indicators of Petroleum Activities & 59 \\
\hline
\end{tabular}

\begin{tabular}{ll}
\hline A7. Indicators of International Competitiveness and \\
Trade Performance
\end{tabular}

\begin{tabular}{lll}
\hline A8. Exports of Goods and Services & 61 \\
\hline
\end{tabular}

\begin{tabular}{lll}
\hline A9. Imports of Goods and Services & 62 \\
\hline
\end{tabular}

\begin{tabular}{lll}
\hline Al0. Current Account Balance & 63 \\
\hline
\end{tabular}

\begin{tabular}{lll}
\hline Al1. Net External Debt & 64 \\
\hline
\end{tabular}

\begin{tabular}{lll}
\hline A12. Labor Market Indicators & 65 \\
\hline
\end{tabular}

\begin{tabular}{ll}
\hline A13. Wages and Prices & 66 \\
\hline
\end{tabular}

\begin{tabular}{lll}
\hline A14. Central Government Finances & 67 \\
\hline
\end{tabular}

\begin{tabular}{ll} 
A15. Local Government Finances & 68 \\
\hline
\end{tabular}

\begin{tabular}{ll} 
A16. General Government Finances & 69 \\
\hline
\end{tabular}

\begin{tabular}{lll}
\hline A17. Interest Rates & 70 \\
\hline
\end{tabular}

\begin{tabular}{lll}
\hline A18. Exchange Rate Developments & 71 \\
\hline
\end{tabular}

\begin{tabular}{ll} 
A19. International Reserves & 72 \\
\hline
\end{tabular} 
Social and Demographic Indicators

\section{Area}

Population (end-1993)

Population growth (1992-93)

GDP per capita (1993)

Population Characteristics and Bealth

(most recent estimates as of December 1989)

Life expectancy at birth: Overall

Female

Infant mortality (aged under 1 , in percent)

Population per physician

Population per hospital bed
323,900 square kilometers

4.3 millions

0.5 percent

USS 26,367

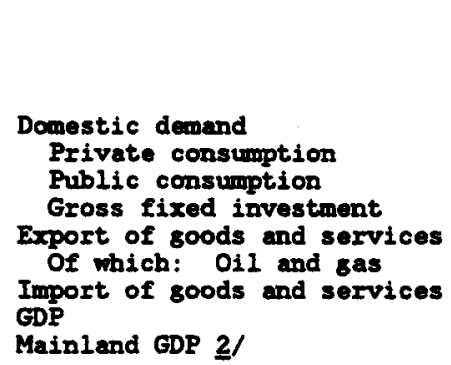

Uneamployment

Persons employed in labor market schemes
1990

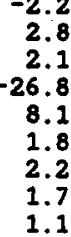

\section{1}

1993

$19941 /$

(Volume chenges in percent)

-1.5
-0.0
2.6
1.7
6.1
17.0
1.7
1.6
-0.6

0.9
1.8
4.4
4.5
6.2
10.8
2.8
3.4
2.1

3.2
1.7
1.8
15.2
1.8
5.8
3.3
2.3
2.0

3.2

4.8

3.1

1.0

8.9

17.3

6.2

5.5

3.5

(In percent of labor force)

\begin{tabular}{rrrrr}
5.2 & 5.5 & 5.9 & 6.0 & 5.5 \\
2.4 & 2.7 & 2.9 & 3.4 & 3.7 \\
4.1 & \multicolumn{4}{r}{ (Eercentage changes) } \\
4.0 & 3.4 & 2.3 & 2.3 & 1.4 \\
-0.7 & 4.7 & 2.8 & 0.9 & 3.0 \\
-0.8 & -1.6 & 1.1 & -1.4 & -1.3 \\
& -2.4 & 0.4 & -2.2 & 0.6
\end{tabular}

Domestic credit

Broad money

Money market interest rate

Government bond yield

State budget, including social security

Revenues

Expenditures

Overall balance

State budget balance, excluding petroleum items

General government financial balance

Current account balance

\section{(Trelve-wonth percent chanse, end of period)}

\begin{tabular}{|c|c|c|c|}
\hline $\begin{array}{l}2.5 \\
5.8\end{array}$ & $\begin{array}{l}-2.8 \\
10.7\end{array}$ & $\begin{array}{l}5.4 \\
7.3\end{array}$ & $\begin{array}{r}-3.1 \\
0.6\end{array}$ \\
\hline
\end{tabular}

\section{(In percent)}

$\begin{array}{lllll}11.4 & 10.6 & 13.7 & 7.6 & 5.7\end{array}$

$\begin{array}{rrrrr}11.4 & 10.7 & 13.7 & 7.6 & 5.7 \\ & 9.9 & 9.8 & 6.5 & 7.2\end{array}$

(In percent of GDP)

$\begin{array}{rrrrr}45.7 & 46.1 & 45.2 & 43.8 & 44.3 \\ 45.2 & 49.0 & 50.1 & 49.8 & 48.3 \\ 0.5 & -2.9 & -5.0 & -6.0 & -4.0 \\ -4.7 & -8.6 & -9.3 & -9.8 & -7.3 \\ 2.5 & -0.2 & -2.3 & -2.6 & -0.9 \\ 3.7 & 4.8 & 2.6 & 2.3 & 3.0\end{array}$

Sources: Ministry of Finance; Norges Bank; Central Bureau of Statistics; WEFA, INTLINE Database; IMF. International Financial Statistics; and staff estimates.

$1 /$ Official estimates as of December 1994

2/ Excludes items related to petroleum exploitation and ocean shipping.

3/ End-October. 


\section{Overview 1/}

Norway's recent economic performance has been quite favorable. A robust and relatively well-balanced recovery has been under way since 1993, with private consumption and non-oil exports rising strongly for the first time in a number of years; employment is growing briskly and, despite an increase in participation rates, unemployment has fallen from its historic highs of the early 1990s; in early 1994, inflation dropped to a thirty-year low, and, at below 2 percent, remains lower than among trading partners; the current account has been in surplus for a number of years and net external debt has been brought to a very low level. The generally favorable macroeconomic conditions prevailing at present mask, on the one hand, a number of structural issues related in particular to the rapid expansion of oil and gas production in the 1970s and 1980s, and on the other, the severity and duration of the stagnation of the mainland economy $2 /$ resulting from the boom and bust associated with financial deregulation and oil related shocks in the 1980 s.

From the mid-1970s when Norway became a major oil and gas producer, the traditional manufacturing sector entered a period of steady decline as the cost competitiveness of the mainland economy was eroded through the process commonly called the "Dutch disease." The expansion of petroleum revenue induced an appreciation of the real exchange rate as the authorities used increased oil and gas revenue to finance higher expenditure, particularly on public sector wages, transfers to households and industry, and infrastructure investment. Periodic devaluations of the krone--the last of which took place in 1986--failed to arrest the appreciation of the real exchange rate, but instead contributed to high domestic cost and price inflation. The overall effect was a contraction of employment in the mainland private sector while public sector employment grew rapidly.

The adverse effects of the "Dutch disease" process on the mainland business economy, were compounded by the bursting of the 1980 s asset price bubble--inflated by financial deregulation and the generous tax treatment of interest payments in the early 1980s--precipitated by the collapse in oil prices in 1986. Private demand for consumption and investment, in both housing and businesses, declined sharply and remained subdued for a number of years, as households and firms went through a prolonged period of financial consolidation, partly coinciding with the international recession of the early 1980s, further squeezing the mainland business sector.

Expansionary fiscal policy from 1989 failed to completely offset the weakness of private demand, with the result that unemployment reached a historic high for Norway--albeit relatively low in the recent European

1/ Prepared by Birgir Arnason.

2/ Excluding activities related to petroleum extraction and ocean shipping. 
context--of around 6 percent of the labor force in the early 1990s. The weakness in activity also contributed to a major banking crisis, with the Government taking over the three largest commercial banks in 1991.

Following the 1986 devaluation, monetary policles were reoriented toward exchange rate stability, with the krone first pegged to a tradeweighted basket of currencies, and from 1990, to the ECU. With the recession generating strong disinflationary pressures--in particular wage moderation associated with rising unemployment--inflation declined sharply, to below that of trading partners in 1989 , where it has since remained. In late 1992, strong speculative pressure against the krone following the ERM currency turmoil and the floating of the Swedish krona and the Finnish markka forced the authorities to delink from the ECU. However, in marked contrast to the other two currencies, the resultant depreciation of the Norwegian krone was only moderate and the authorities have maintained their emphasis on preserving exchange rate stability vis-a-vis European currencies.

This paper reviews recent economic developments in Norway, with an emphasis on developments in 1993 and 1994. The main text covers developments in the real economy, in the public finances and in the monetary and exchange rate area. Five appendices cover specific topics in more detail. The first appendix presents estimates of potential output for the mainland economy, as well as of the NAIRU in Norway. Building on the first appendix, the second presents preliminary estimates of the development of the structural balance for general government over the perfod 1988-95. The third appendix describes the expansion of the Norwegian petroleum sector and its macroeconomic impact on the rest of the economy. The fourth appendix reviews in detail the "Dutch disease" process in the Norwegian context. The last appendix reviews recent developments in the banking sector with a focus on the resolution of the banking crisis.

\section{Developments in the Real Economy 1}

\section{Background}

As a result of the sharp contraction of the mainland economy towards the end of the 1980s and the sluggish recovery at the beginning of the 1990s, by 1992 mainland output had still not surpassed its previous peak in 1987 (Chart 1). Over this period, all the private components of domestic demand, including private consumption and housing, and mainland business investment, were weak while public consumption and investment, and investment in the petroleum sector--even if volatile--were relatively strong (Chart 2). Because of steadily increasing oil and gas production, total GDP did not perform as poorly, registering a decline only in 1988 . Since the second half of 1993, however, a relatively robust recovery has been underway

1/ Prepared by Birgir Arnason. 
CHART 1

NORWAY

\section{OUTPUT AND EXPENDITURE}
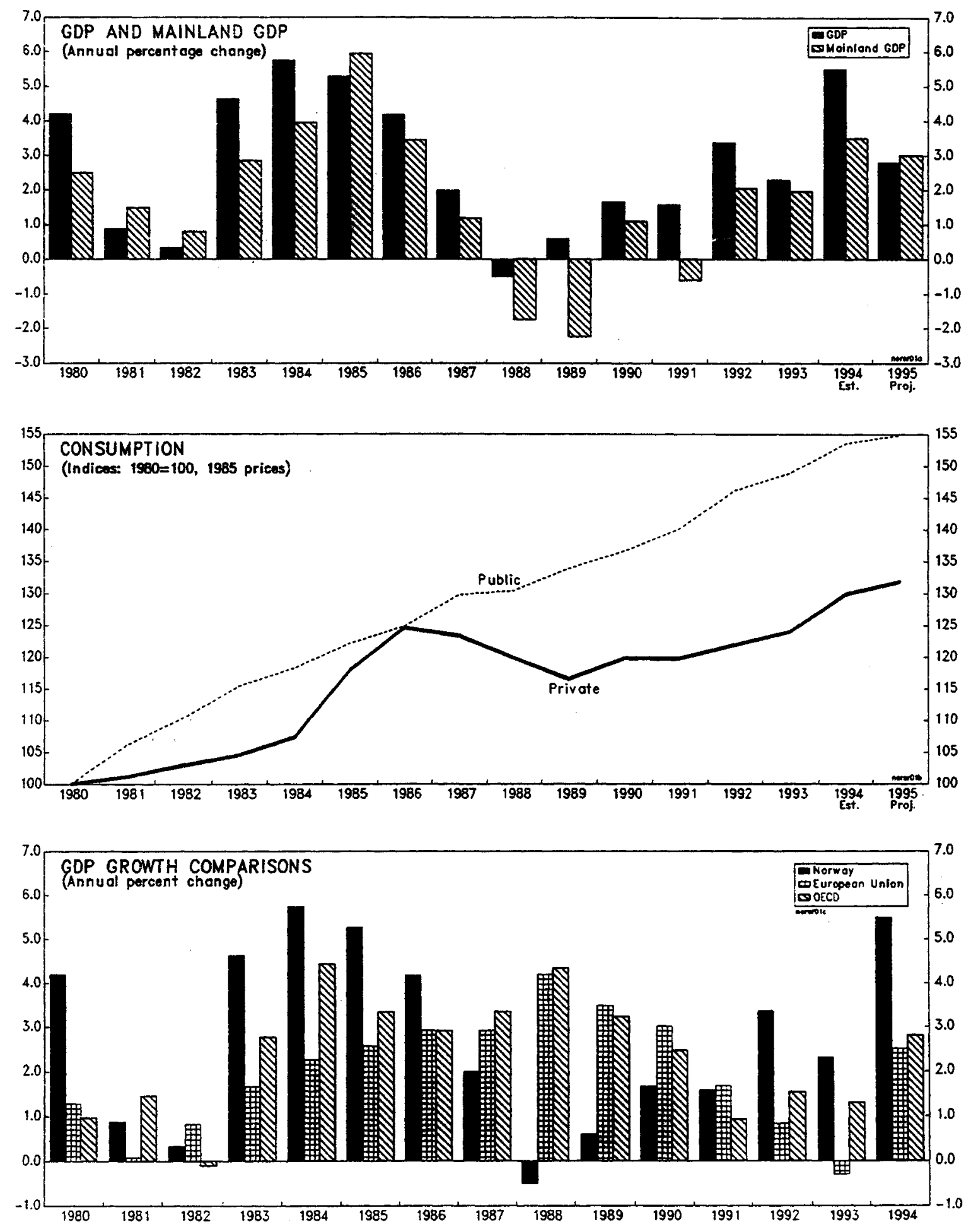

Sources: Centrol Bureau of Statistics; Ministry of Finance; and OECD, Main Economic Indicators. 
CHART 2

NORWAY

FIXED INVESTMENT

(Indices: $1980=100,1985$ prices)
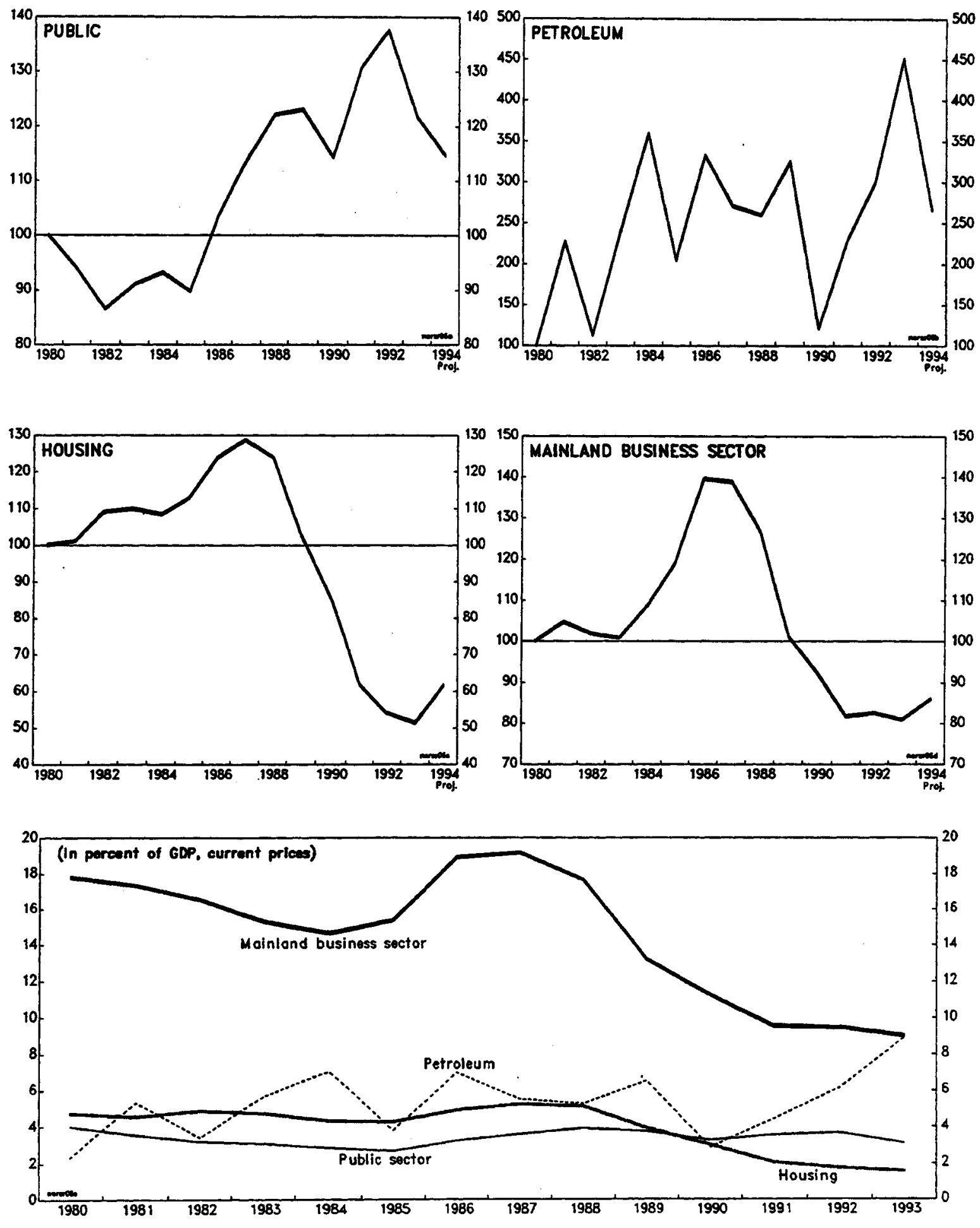

Sources: Centrol Bureau of Stotistics. 
in the mainland economy, led by a rebound in private consumption and a rise in traditional exports (such as metals and forestry products), which tend to expand rapidly during the early phase of recovery in the international economy.

\section{Domestic demand}

Total domestic demand declined every year during 1988-91, by a cumulative 8 percent. Demand from the mainland economy was somewhat more erratic but, nevertheless, declined by a total of close to 9 percent over this period. Domestic demand expanded in 1992--total demand by 1.7 percent and mainland demand by 2.3 percent--but largely because of a substantial increase in public consumption and petroleum investment.

\section{a. Private consumption and household saving}

Private consumption was particularly weak towards the end of the 1980 s and in the early part of the 1990s, despite modest growth of real disposable income when households attempted to strengthen their balance sheet in response to a decline of more than a third in housing prices in real terms during 1987-92, and a less generous tax treatment of interest payments introduced with the tax reforms of 1992. The saving rate, which had fallen to an all time low of close to minus 5 percent of disposable income during the mid-1980s, rose during this period reaching its pre-financial deregulation level of close to 5 percent by 1992. However, the composition of saving was different, with financial saving accounting for the bulk of the total whereas previously investment in housing had accounted for the largest share of household saving.

Private consumption remained weak through the first half of 1993 but picked up sharply during the second half of the year, as declining interest rates and rising housing prices boosted consumer confidence. Seasonally adjusted, private consumption rose by 3.5 percent between the first and second halves of 1993, giving a rise of 1.7 percent over 199.2. Purchases of cars and other durable goods grew particularly strongly, or by close to 10 percent from the first half to the second half of 1993 . The saving rate remained unchanged from 1992, at above 5 percent of disposable income.

The strong growth of private consumption continued into 1994, with seasonally adjusted growth of 1.7 percent being recorded in the first quarter. Purchases of cars and durable goods continued at a high level when compared with previous years. Consumption growth slowed in the second quarter of 1994 but recovered again in the third quarter to a seasonally adjusted 1.5 percent. For 1994 as a whole, private consumption is estimated to have been 4.8 percent higher than in 1993 (Table 1). With real disposable income rising by an estimated 2.5 percent in 1994 , this implies a decline in the household saving rate to below 4 percent of disposable income. However, households have by now rebuilt their finansial assets that had been eroded in the 1980 s. 
Table 1. Domestic Demand and Output (percentage change from previous year)

$\begin{array}{lrrrrr} & 1990 & 1991 & 1992 & 1993 & 19941 / \\ \text { Private consumption } & 2.8 & 0.0 & 1.8 & 1.7 & 4.8 \\ \text { Public consumption } & 2.6 & 2.1 & 2.6 & 4.4 & 3.1 \\ \text { Gross fixed investment 2/ } & -14.5 & -2.0 & -0.5 & 4.7 & 1.0 \\ \quad \text { Housing } & -17.1 & -27.3 & -12.6 & -5.2 & 20.0 \\ \quad \text { Mainland business sector } & -5.1 & -5.9 & 4.7 & -1.2 & 5.0 \\ \quad \text { Public sector } & -7.1 & 14.4 & 5.3 & -11.6 & -6.1 \\ \quad \text { Petroleum sector 2/ } & -12.7 & 31.0 & 8.6 & 15.9 & -14.2 \\ \text { Domestic demand } & -1.0 & -0.5 & 1.7 & 3.0 & 4.0 \\ \text { GDP } & 1.7 & 1.6 & 3.4 & 2.3 & 3.5 \\ \text { Mainland domestic demand } & 1.6 & -1.1 & 2.3 & 1.4 & 4.7 \\ \text { Mainland GDP } & 1.1 & -0.6 & 2.1 & 2.0 & 3.5\end{array}$

Sources: Central Bureau of Statistics, Ministry of Finance. 1 Official estimates.

2/ Including Investment in o11 platforms under construction.

\section{b. Public Consumption}

In contrast to private consumption, public consumption, at both central and local government levels, increased steadily during the late 1980s and early 1990s. The increase was particularly sharp in 1992 at 4.4 percent. Public consumption growth slowed to 1.8 percent in 1993 but rose again to 3.1 percent in 1994, as increased revenue allowed local governments to increase expenditure. The growth of central government consumption expenditure rose only marginally between 1993 and 1994 , from 1.6 percent to 1.9 percent.

\section{c. Gross fixed investment}

Housing investment and mainland business sector investment were particularly hard hit in the late 1980 s and early 1990s. During this period housing investment declined by more than a half as prices of new homes exceeded secondary market prices by a significant margin; mainland business sector investment declined by close to 40 percent because of the weakness of mainland domestic demand but also because of the credit driven creation of excess capacity in the early 1980s. On the other hand, public investment rose by almost 40 percent from 1986-92. Investment in the petroleum sector, although highly variable, was also generally high during the latter half of the 1980s, but declined sharply in 1990. Overall, gross fixed investment contributed modestly to output growth in this period.

Housing investment remained weak into 1993, but with interest rates rising and housing prices on the rebound, there was a clear pick up in the second half of the year. Nevertheless, for 1993 as a whole housing 
investment declined by more than 5 percent from 1992. With housing prices continuing to rise in the first half of 1994, housing investment continued to strengthen, and--although housing prices stabilized in the second half of the year--is estimated to have risen by 20 percent over its 1993 level.

Mainland business investment increased somewhat in 1992 for the first time in many years but declined again in 1993 by 1.3 percent. Although there were few signs of a rebound until the third quarter of 1994, mainland business sector investment is, nevertheless, estimated to have increased by 5 percent over 1993. With the winding down of investment projects related to the 1994 Winter 0lympics, public investment declined by almost 12 percent in 1993 and by more than 6 percent in 1994. Petroleum investment, on the other hand reached an all-time peak in 1993, growing by 16 percent and accounting for more than a third of gross fixed investment. In 1994, petroleum investment declined by an estimated 14 percent. Overall, gross fixed investment increased by 4.7 percent in 1993 and an estimated 1 percent in 1994. 1

On the whole total domestic demand increased by 3 percent in 1993 and another 4 percent in 1994. Mainland demand, on the other hand, increased by 1.4 percent in 1993 and an estimated 4.7 percent in 1994.

\section{The external current account}

Having fallen into deficit after the collapse in oil prices in 1986, the current account was brought back into surplus in 1990 on the strength of rapidly expanding oil and gas exports (Chart 3 ). In recent years, the current account surplus has averaged close to 3 percent of GDP (Table 2). However, adjusted for oil and gas exports, the current account has recorded a relatively stable deficit in excess of 10 percent of GDP.

\section{a. Exports of goods and services}

Exports of traditional goods 2/ were significantly affected by the international downturn in the early 1990s. Export volumes flattened out and prices for important raw material exports, especially metals, fell sharply. These developments were reversed in 1993 and especially in 1994.

Traditional exports grew by 3 percent in 1993 and an estimated 13 percent in 1994. While some export prices continued to decline in 1993, raw aterial prices rose sufficiently to leave overall export prices unchanged frod 1992. In 1994, export prices are estimated to have risen by 2 percent. According to estimates from the Ministry of Finance, traditional Norwegian exports increased their market share by more than 8 percent between 1991 and 1994 .

1/ Inclusive of investment in oil platforms under construction.

2f Goods other than oil, gas, oil platforms, and ships. 
Table 2. External Current Account (percentage change unless otherwise noted)

\begin{tabular}{|c|c|c|c|c|c|}
\hline & 1990 & 1991 & 1992 & 1993 & 19941 \\
\hline $\begin{array}{r}\text { Exports of goods } \\
\text { and services }\end{array}$ & & & & & \\
\hline $\begin{array}{l}\text { O1l and gas } \\
\text { Other goods }\end{array}$ & $\begin{array}{l}0.1 \\
1.8 \\
9.9\end{array}$ & $\begin{array}{r}6.1 \\
17.0 \\
-2.7\end{array}$ & $\begin{array}{r}6.2 \\
10.8 \\
4.1\end{array}$ & $\begin{array}{l}1.8 \\
5.8 \\
3.0\end{array}$ & $\begin{array}{r}8.9 \\
17.3 \\
13.0\end{array}$ \\
\hline Imports of goods & & & & & \\
\hline $\begin{array}{l}\text { and services } \\
\text { Current account }\end{array}$ & 0.9 & 2.2 & 1.7 & 2.8 & 6.2 \\
\hline $\begin{array}{l}\text { (percent of GDP) } \\
\text { Non-oil current account }\end{array}$ & $\begin{array}{r}3.6 \\
-9.7\end{array}$ & $\begin{array}{r}4.8 \\
-9.3\end{array}$ & $\begin{array}{r}2.5 \\
-11.2\end{array}$ & $\begin{array}{r}2.3 \\
-11.9\end{array}$ & $\begin{array}{r}3.0 \\
-11.3\end{array}$ \\
\hline
\end{tabular}

Sources: Central Bureau of Statistics, Ministry of Finance. 1) Official estimates.

Norwegian oil and gas exports have grown rapidly over the last few years, as a result of a high level of investment in expanded production capacity. 1/ In volume terms, petroleum exports increased by more than 60 percent between 1990-94, with about half of the increase coming in 1993 and 1994, when exports increased by 5.8 percent and 17.3 percent, respectively. After falling by more than half in 1986, the price for Norwegian oil exports $2 /$ has remained fairly stable in kroner terms, apart from a brief spike in late 1990, at around NKr 120 per barrel. The price of oil averaged NKr 123 per barrel in 1993 but declined to an average of Nkr 110 per barrel in 1994.

Overall, exports of goods and non-factor services increased by 1.8 percent and an estimated 8.9 percent in 1993 and 1994, respectively.

\section{b. Imports of goods and services}

Because of the weakness of domestic demand, imports of traditional goods were generally weak in the late 1980s and early 1990s. 3/ Imports did not pick up noticeably in 1993, but much more so in 1994, especially of cars and other durable goods, corresponding to the increase in private consumption. Traditional imports increased by just under 2 percent in 1993 but by an estimated 12 percent in 1994. Overall, imports of goods and nonfactor services increased by 2.8 percent and an estimated 6.2 percent in 1993 and 1994, respectively.

1. See Appendix III for more detail about the Norwegian petroleum sector.

2) To which the price of gas exports is also linked.

3/ 1990 was an exception when imports of transportation equipment, including for the military, were particularly high. 


\section{EXTERNAL DEVELOPMENTS}
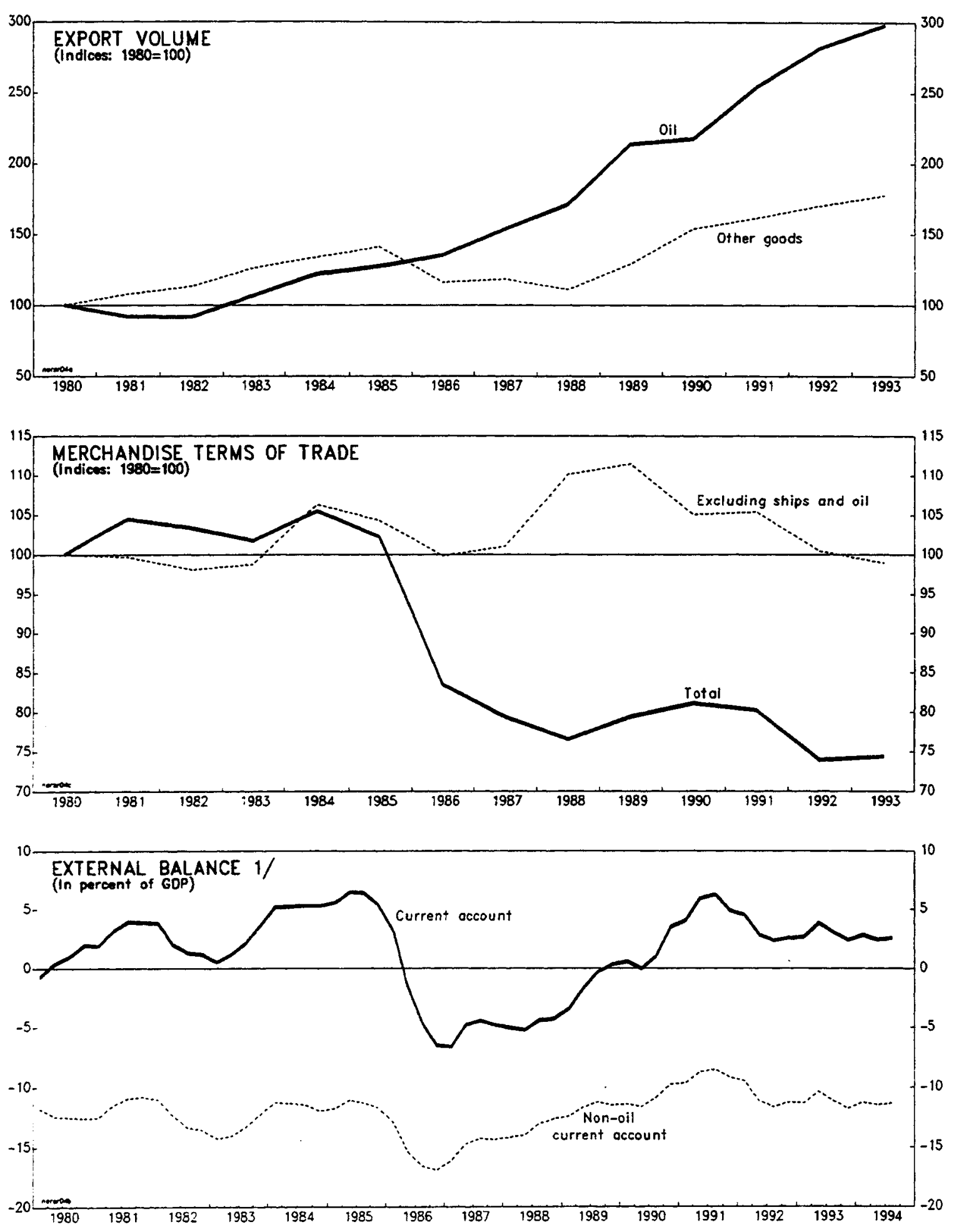

Source: Dotc provided by Norwegion authorities.

1) Four-quarter moving overoge. 
This page intentionally left blank

CInternational Monetary Fund. Not for Redistribution 


\section{c. The current account balance}

Norway's current account surplus has averaged close to 3 percent of GDP in the 1990s. With Norway making significant net invisible payments abroad, in the form of factor payments and official development assistance, the balance of trade in goods and non-factor services has been substantially larger, of the order of 7 percent of GDP. Because of relatively weak export performance in 1993, the current account surplus declined somewhat to 2.3 percent of GDP from 2.5 percent in 1992. In 1994, on the other hand, a robust increase in imports was more than outweighed by increased exports, leading to an expansion of the current account surplus to 3 percent of GDP.

The current account surpluses of recent years have enabled Norway to reduce its net external debt from above 20 percent of GDP in the late 1980s to close to 5 percent at the end of 1994. The composition of the debt has also shifted notably, with the net debt of the private sector declining relative to that of the public sector, especially central government.

\section{Output}

Overall, total GDP increased by 2.3 percent in 1993 and an estimated 5.5 percent in 1994, whereas mainland output expanded by 2 percent in 1993 and an estimated 3.5 percent in 1994, underlining the breadth of the recovery.

An examination of developments in production across sectors also confirms that the recovery is reasonably well-balanced, although oil and gas production continues to contribute strongly to the expansion of total GDP (Table 3). Of the 2.3 percent expansion in GDP in 1993, the mainland business sector and the petroleum sector each contributed about 1 percentage point, the public sector around 0.5 percentage points, while ocean shipping made a negative contribution of 0.2 percentage points. Of the 5.5 percent growth in 1994, the mainland business sector and the petroleum sector continued to contribute the lion's share of growth- -2.3 percentage points and 2.9 percentage points, respectively--while the contributions of the public sector and of ocean shipping were unchanged from 1993--at 0.5 percentage points and minus 0.2 percentage points, respectively.

\section{Prices, wages and competitiveness}

Apart from a brief period following the devaluation of the krone in 1996, consumer price inflation in Norway has been on a downward trend since the early 1980s (Chart 4). By 1989, Norwegian inflation had fallen below the average among trading partners. In early 1994, the 12-month rate of consumer price increases fell below 1 percent for the first time in thirty years. In the second half of 1994, the measured rate of price increases rose again largely as a result of an increase in excise taxes on tobacco, automotive fuels and cars from July 1, 1994. In December 1994, the 12-month 
Table 3. Contributions to Growth in 1993 and 1994

\begin{tabular}{|c|c|c|c|c|}
\hline & \multicolumn{2}{|c|}{1993} & \multicolumn{2}{|c|}{1994} \\
\hline & $\begin{array}{l}\text { Percent } \\
\text { change }\end{array}$ & $\begin{array}{c}\text { Contribution } \\
\text { to growth }\end{array}$ & $\begin{array}{l}\text { Percent } \\
\text { change }\end{array}$ & $\begin{array}{c}\text { Contribution } \\
\text { to growth }\end{array}$ \\
\hline $\begin{array}{l}\text { Public sector } \\
\text { Mainland business }\end{array}$ & 2.8 & 0.5 & 3.0 & 0.5 \\
\hline $\begin{array}{l}\text { sector } \\
\text { Mainland GDP } \\
\text { Petroleum sector } \\
\text { Ocean shipping } \\
\text { Total GDP }\end{array}$ & $\begin{array}{r}1.8 \\
2.0 \\
6.0 \\
-6.9 \\
2.3\end{array}$ & $\begin{array}{r}1.1 \\
1.6 \\
1.0 \\
-0.2 \\
2.3\end{array}$ & $\begin{array}{r}3.7 \\
3.5 \\
16.6 \\
-5.3 \\
5.5\end{array}$ & $\begin{array}{r}2.3 \\
2.8 \\
2.9 \\
-0.2 \\
5.5\end{array}$ \\
\hline
\end{tabular}

Source: Staff estimates.

inflation rate stood at 1.9 percent and the average increase in consumer prices over 1993 was 1.4 percent.

Along with the emphasis on exchange rate stability pursued since 1986, wage moderation in the face of rising unemployment has contributed importantly to the slowing down of inflation. After increasing by close to 10 percent per year on average during the 1980s, increases in average hourly wage costs in manufacturing moderated steadily during 1990-93. In nominal terms, these increases were 5.7 percent in 1990, 4.7 percent in 1991, 2.8 percent in 1992, and only 0.9 percent in 1993, when employer's social security contributions were also lowered. In 1994, hourly wage costs are estimated to haven risen by around 3 percent, fairly close to the underlying rate of increase in two previous years.

Despite relatively poor productivity performance in recent years, the slow rate of increase in wage costs, as well as some effective depreciation of the krone, especially in the wake of the delinking from the ECU in late 1992, has led to a significant improvement in the cost competitiveness of the mainland economy. From 1988-94, Norwegian relative unit labor costs in manufacturing declined by a total of 12 percent, representing an important step towards reversing the losses in competitiveness experienced in the 1970 s and 1980s. I/

\section{Employment and unemployment}

Employment peaked in 1987, whereafter it fell sharply as the mainland recession was felt. In the early 1990s, the level of employment stabilized at about 5 percent below its 1987 peak. Although the labor force also shrank because of declining participation rates, open unemployment rose steeply in the early 1990 s despite a substantial expansion of active labor

1) See Appendix IV. 


\section{INFLATION AND UNEMPLOYMENT}
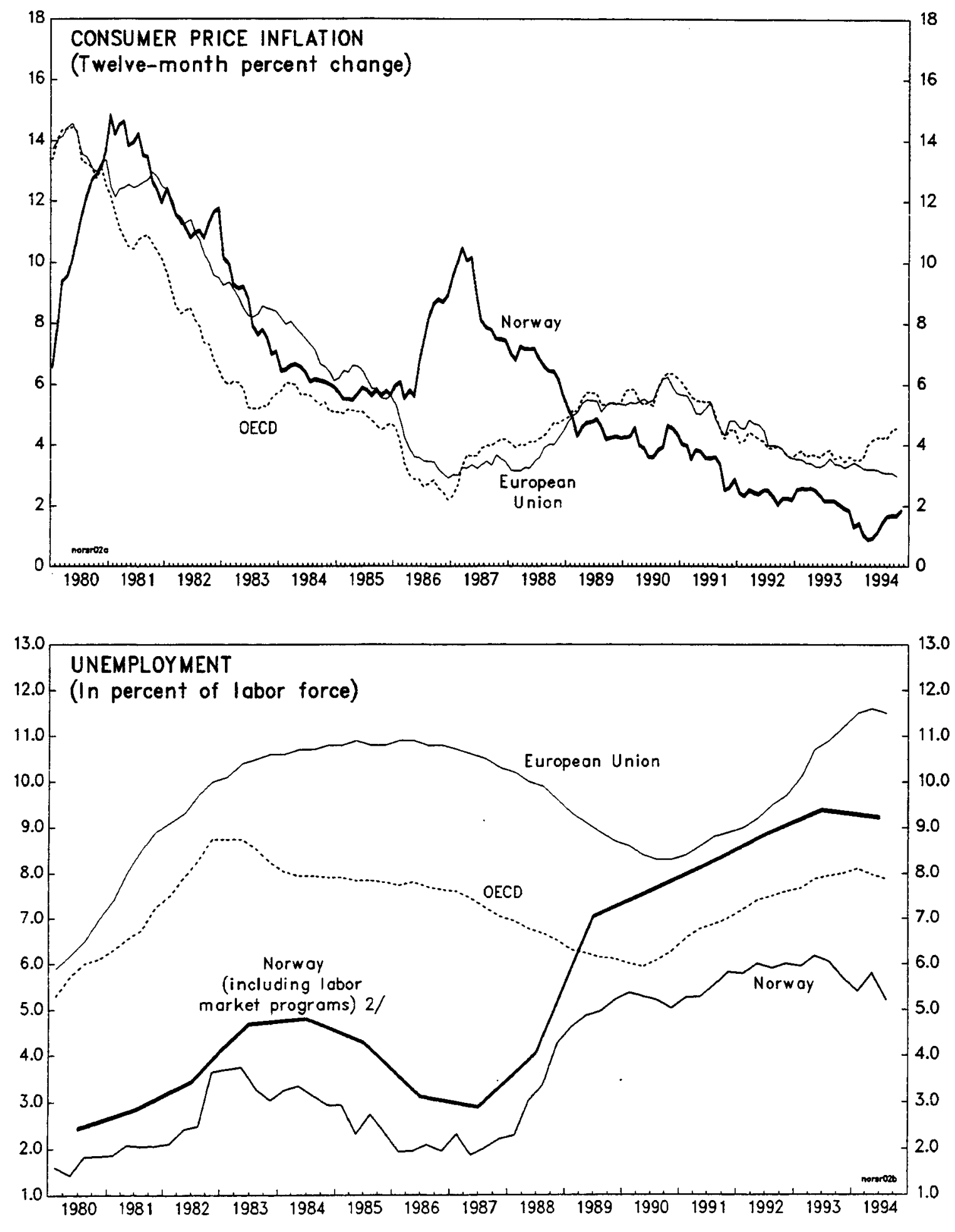

Sources: Central Bureau of Statistics; and OECD, Main Economic Indicators.

1) The labor market programs include special programs for the disabled. 
This page intentionally left blank

CInternational Monetary Fund. Not for Redistribution 
market programs. Having averaged between 2-3 percent of the labor force through most of the $1980 \mathrm{~s}$, with labor market programs typically engaging 1-2 percent of the labor force, the unemployment rate rose to 5.9 percent of the labor force in 1992 and 6 percent in 1993, despite more than a doubling of labor market programs to cover more than 3 percent of the labor force. 1/ Thus, overall unemployment went from being 3-4 percent of the labor force in the 1980 s to 9 percent in the early 1980s. Although some of this increase was clearly cyclical, another part was structural. It has been estimated that structural unemployment--excluding labor market programs--rose from below 2 percent of the labor force in the 1970 s to 5 percent in the early 1980s. 2J

The employment level reached a trough in early 1993 and employment grew in the second half of the year, as the mainland economy began to recover. However, for the year as a whole the employment level was only marginally higher than in 1992. In 1994, on the other hand, as the recovery firmed, employment is estimated to have increased by 1.5 percent over 1993 , giving room for a 0.5 percentage point reduction in the annual average unemployment rate to 5.5 percent of the labor force--the seasonally adjusted rate in the third quarter was down to 5.2 percent--despite considerable re-entry into the labor force. Labor market programs were maintained at about their 1993 level.

\section{Public Finance $3 /$}

\section{Background}

In an effort to boost economic activity and sustain unemployment, fiscal policy became decidedly expansionary towards the end of the $1980 \mathrm{~s}$ (Chart 5). According to official estimates, the state budget imparted a positive demand impulse to the economy in each of the years from 1989-92, for a cumulative total of around 7 percent of GDP. 4/ Over this period, the state budget balance deteriorated sharply, going from a small surplus in the late 1980s to a deficit of more than 5 percent of GDP in 1992. Increased expenditure, especialiy on transfers to households, contributed substantially to this deterioration in the budget balance. The oll-adjusted state budget balance registered a corresponding deterioration.

1) This figure includes some special programs for the disabled.

2) See Appendix I. An account of the factors that may underlie the structural deterioration of the Norwegian labor market is in OECD Economic Survey: Norway 1994, OECD, 1994.

3/ Prepared by Birgir Arnason.

4/ Analysis by the staff of the changes in the structural balance of general government reported in Appendix II point in the same direction. 
In 1993, the authorities acknowledged I/ that fiscal expansion had been pushed to the limits and that fiscal consolidation over the medium-term was warranted, not least to preserve room for manoeuvre in fiscal policy in future downturns in the economy. Overall expenditure restraint--interpreted as maintaining growth of current expenditure below the growth of mainland output--was seen as the chief means of achieving fiscal consolidation. The authorities also indicated that it would be desirable to shift some expenditure away from transfers to households and towards purchases of goods and services which would have a stronger effect on employment. The main features of the tax system, in place following comprehensive tax reform in 1992 would be preserved. 2/

\section{The 1993 state budget and outturn}

The 1993 budget aimed at an overall state budget deficit of just under 7 percent of GDP--an increase of 1 percentage point over 1992--partly because of increased investment in the oil sector. In the event, the overall deficit, as well as the oil-adjusted deficit, turned out marginally larger than budgeted (Table 4).

Table 4: State Budget Balance, 1993

(percent of GDP or mainland GDP 1/)

$19921993 \quad 1993$

Outturn 2/ Budget $3 /$ Outturn 4/

Total revenue

Excluding petroleum revenue

44.6

44.5

43.9

Total expenditure

46.4

45.7

45.5

50.5

51.3

51.0

Excluding petroleum expenditure

58.0

58.2

58.3

Overall balance

$-5.8$

$-6.8$

$-7.1$

Oil-corrected balance

$-11.8$

$-12.5$

$-12.8$

Source: Ministry of Finance

1/ Total figures are in relation to GDP; oil-corrected figures in relation to mainland GDP.

2f As estimated at the time of presentation of 1993 budget.

3/ National Budget for 1993.

4f As estimated at the time of presentation of 1994 budget.

1/ See The Long-Term Program 1993-97, Ministry of Finance, 1993.

2) The reforms consisted of a comprehensive transformation of income taxation of individuals and households, businesses and capital towards broader tax bases, lower marginal tax rates and few distortions. For a review of the tax reforms, see OECD Economic Surveys: Norway 1990/1991, OECD, 1991. 


$$
\begin{aligned}
& -10 \mathrm{a}- \\
& \text { CHART } 5
\end{aligned}
$$

NORWAY

PUBLIC FINANCE
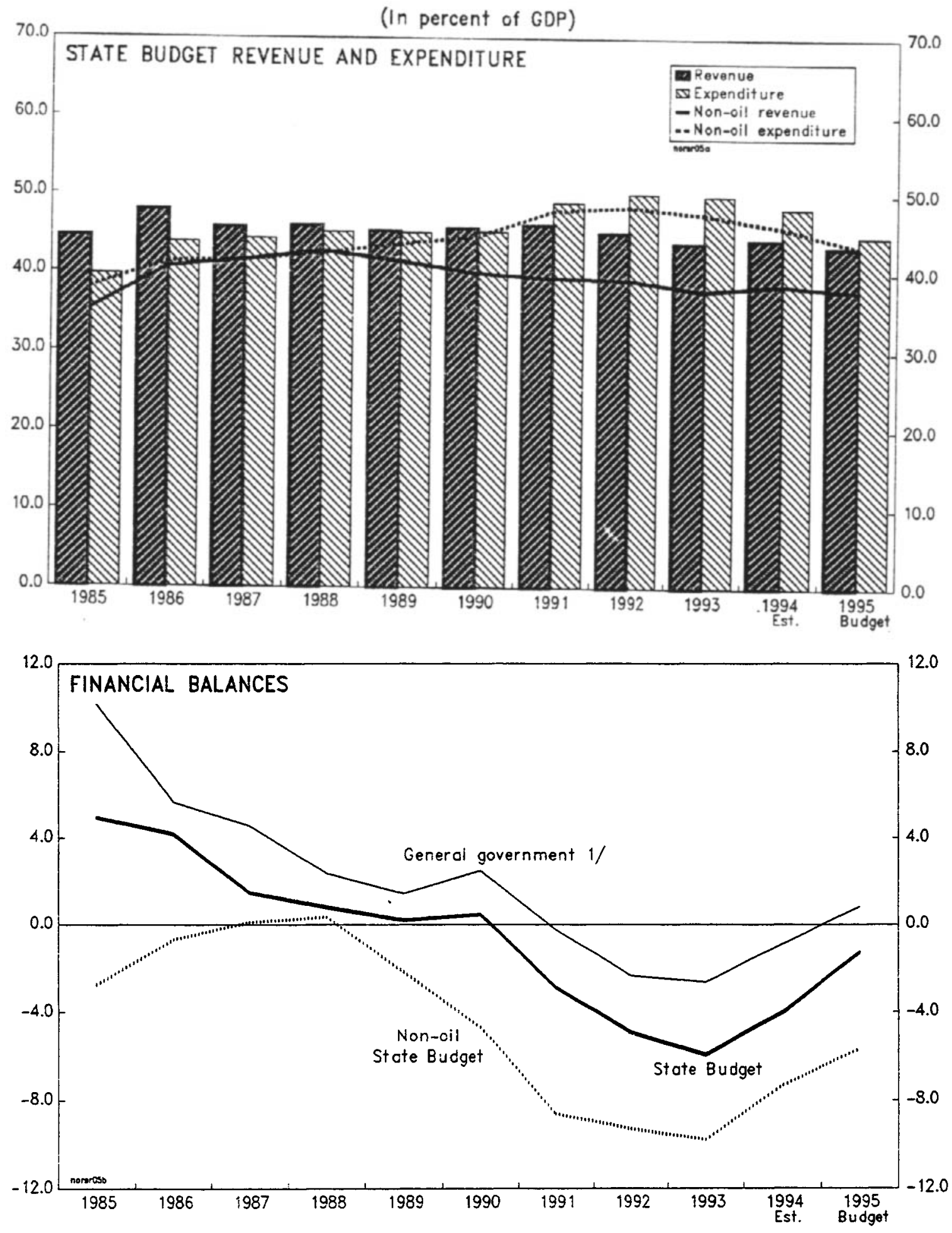

Source: Ministry of Finance.

1) Consistent with Maostrict criteria. 
This page intentionally left blank

CInternational Monetary Fund. Not for Redistribution 


\section{a. Revenue}

On the revenue side, the 1993 budget was based on broadly unchanged income and excise taxes. Marginal tax rates were left unchanged and deductions and income thresholds were raised by the expected rate of wage increase of 2.8 percent. Similarly, most excise taxes expressed in nominal terms were raised by the expected increase in consumer prices of 2 percent. 011 prices were expected to increase slightly in real terms. During the finalization of the budget by Parliament in late 1992, around the time of the delinking of the krone from the ECU, it was decided to lower the employers' social security contribution rate by 2.4 percentage points in order to strengthen the coupetitiveness of the mainland economy. This was offset in a revenue-neutral fashion by a 2 percentage point increase in the VAT rate, from 20 to 22 percent.

Revenue in 1993 turned out fairly close to the budgeted level. Revenue from the mainland economy turned out at 45.5 percent of mainland output, only 0.2 percentage points lower than budgeted. Total revenue, at 43.9 percent of GDP, was about 0.6 percent lower than budgeted, in part because the anticipated increase in oll prices did not materialize.

\section{b. Expenditure}

On the expenditure side, the main goal included in the 1993 budget was to maintain the underlying growth of non-oil expenditure at about the rate of growth of mainland output. In this the authorities were quite successful as non-oil expenditure, at 58.3 percent of mainland GDP, was only 0.1 percentage point higher than budgeted. Also, total expenditure turned out slightly lower in relation to GDP than planned.

Overall, the 1993 budget imparted to the economy a demand stimulus equal to about 0.5 percent of GDP.

\section{The 1994 state budget and outturn}

The 1994 budget aimed for a reduction in the overall budget deficit of around 1 percentage point of GDP, from 7.1 percent of GDP to 6.1 percent. A similar reduction was to be achieved in the non-oil budget deficit. As it turned out, the unexpected strength of the economy led to a considerably sharper fall in the budget deficits, with the overall deficit declining to 4.0 percent of GDP and the non-oil deficit to 8.9 percent of mainland GDP (Table 5).

\section{a. Revenue}

As in the 1993 budget, the 1994 budget represented an essential continuation of the tax system established in 1992. Deductions and income thresholds were raised by 2 percent in line with expected wage growth. The tax rate on large wealth holdings was raised somewhat. Excise taxes expressed in nominal terms were in general raised by the expected inflation 
rate, but some additional increases in excise taxes on tobacco, gasoline, and cars were added in revisions to the budget for mid-1994.

Because of the strength of the recovery, revenue turned out considerably greater than expected: total revenue at 44.8 percent of GDP, 1.1 percentage point greater, non-0il revenue at 46.9 percent of mainland GDP, 1 percentage point greater.

Table 5: State Budget Balance, 1994

(percent of GDP or mainland GDP $1 /$ )

$\begin{array}{ccc}1993 & 1994 & 1994 \\ \text { Outturn 2/ } & \text { Budget } 3 / & \text { Outturn } 4 /\end{array}$

$\begin{array}{lrrr}\text { Total revenue } & 43.9 & 43.7 & 44.8 \\ \text { Excluding petroleum revenue } & 45.5 & 45.5 & 46.9 \\ \text { Total expenditure } & 51.0 & 49.9 & 48.9 \\ \text { Excluding petroleum expenditure } & 58.3 & 57.5 & 55.8 \\ \text { Overall balance } & -7.1 & -6.1 & -4.0 \\ \text { Oil-corrected balance } & -12.8 & -11.7 & -8.9\end{array}$

Source: Ministry of Finance

1/ Total figures are in relation to GDP; oil-corrected figures in relation to mainland GDP.

2/ The outturn at the presentation of the 1994 budget.

3/ National Budget for 1994.

4/ Final Budget for 1995.

\section{b. Expenditure}

On the expenditure side, the 1994 budget aimed at keeping underlying expenditure growth at around 1 percent, on the expectation that mainland output would expand by 1.8 percent. This expenditure restraint was to be achieved, inter alia, by maintaining some transfers in nominal terms from 1993. Mainland GDP expanded considerably faster, and non-oil expenditure fell sharply in relation to mainland GDP, or to 55.8 percent compared with 58.3 percent in 1993. Total expenditure also declined in relation to GDP, going from 51 percent in 1993 to 48.9 percent in 1994.

The 1994 budget is estimated to have imparted a negative demand impulse of close to 1 percent of GDP, inter alia because of the extra excise tax increases in mid-1994.

\section{The 1995 state budget}

The 1995 budget, presented in October 1994, was aimed at an overall state budget deficit of 2.6 percent of GDP, or 1.4 percentage points lower than in 1994. However, it was also announced that the budget would need to be revised irrespective of the outcome of the EU referendum in late 
November. In the event, EU nembership was rejected and the authorities felt it necessary to strengthen the budget for 1995 in order to demonstrate their commitment to sound economic policies. As passed, the 1995 budget aims at an overall deficit of 1.4 percent of GDP and an oil-corrected deficit of 7 percent of mainland GDP, and is estimated to restrain demand by the equivalent of 1.3 percent of GDP (Table 6).

On the revenue side, the most important measure is an increase in the VAT rate from 22 to 23 percent--equivalent to almost 0.5 percent of GDP in revenue--while expenditure on various posts is also reduced by the equivalent of 0.3 percent of GDP. Total revenue in will decline only marginally in relation to GDP from 1994, whereas total expenditure is to decline by about 2.5 percentage points in relation to GDP.

Table 6. State Budget for 1995

(percent of GDP or mainland GDP $1 /$ )

1994

Outturn 2/
1995

Budget 3/
1995

Budget 2/

Total revenue

Excluding petroleum revenue

Total expenditure

Excluding petroleum expenditure

Overall balance

Oil-corrected balance

$\begin{array}{lll}44.8 & 43.5 & 44.0 \\ 46.9 & 45.4 & 46.2 \\ 48.9 & 46.1 & 45.4 \\ 55.8 & 53.4 & 53.2 \\ -4.0 & -2.6 & -1.4 \\ -8.9 & -7.9 & -7.0\end{array}$

Source; Ministry of Finance.

1) Total figures are in relation to GDP, oil-corrected figures in relation to mainland GDP.

2/ Final budget for 1995 .

3) National budget for 1995 .

\section{General government balances in 1993-94}

For a number of reasons, the accounts for the state budget dlffer in important respects from the accounts of general government on a national accounts basis (consistent with Maastricht criteria). As a result the general government balance can differ significantly from the state budget balance. Among the more important reasons are that the general government accounts include social security funds not totally included in the state budget, the state budget counts equity investment in state enterprises.especially in the petroleum sector--as current expenditure whereas it is not included in the general government accounts, and the state budget accounts are presented on a cash basis while the general government accounts are presented on an accruals basis. That the general government accounts also include local governments is of relatively minor importance for Norway, as the accounts of the latter have been in approximate balance in recent years. 
Table 7 compares the state budget deficit with that of general government over 1993-94. Because of the sizable surpluses in social security funds and the large investment in the petroleum sector, the general government deficit has been significantly smaller than the state budget deficit in recent years. In 1994, the general government deficit is estimated to have been 0.9 percent of GDP, whereas the overall state budget deficit was put at 4.0 percent of GDP. In 1995, the general government balance should have returned to a surplus of 0.8 percent of GDP.

Table 7: State Budget and General Government Balances, 1992-94 (percent of GDP)

$\begin{array}{lrrr} & 1993 & 1994 & 1995 \\ \text { Overall state budget balance } & -7.1 & -4.0 & -1.4 \\ & & & \\ + \text { Definitional differences } & 0.0 & 0.1 & 0.1 \\ + \text { Surpluses in social security funds } & 1.0 & 1.0 & 0.3 \\ \text { - Central government balance, cash basis } & -6.1 & -2.9 & -0.9 \\ + \text { Equity investment in state enterprises } & 2.3 & 1.8 & 1.7 \\ \text { - Central government financial balance } & -3.8 & -1.1 & 0.8 \\ + \text { Local government balance } & 0.1 & 0.4 & -0.1 \\ + \text { Accrued but unpaid taxes } & 0.5 & -0.2 & 0.1 \\ \text { - General government balance } & -3.2 & -0.9 & 0.8\end{array}$

Source: Ministry of Finance.

\section{Military expenditure}

Defense expenditure in Norway has been fixed in nominal terms in recent years at close to NKr 23 billion per year. As a result, military expenditure has gradually declined in relation to both total expenditure and GDP. In 1992, military expenditure accounted for 6.3 percent and 3.1 percent of total expenditure and GDP, respectively.

Table 8. Military expenditure, 1991-95

$\begin{array}{lrrrrr} & 1991 & 1992 & 1993 & 1994 & 1995 \\ & & & & & \\ \text { NKr billion } & 22.4 & 23.0 & 23.0 & 23.5 & 23.6 \\ \text { Percent of total expenditure } & 6.7 & 6.5 & 6.3 & 6.3 & 6.5 \\ \text { Percent of GDP } & 3.3 & 3.3 & 3.1 & 3.1 & 2.9\end{array}$

Source: Ministry of Finance. 


\section{Monetary and Exchange Rate Developments and Policy 1 /}

\section{Background}

Norway's financial deregulation in the early 1980s marked a departure from administrative control towards a monetary policy implemented through indirect instruments such as official interest rates aimed at influencing the development of money market rates. Monetary policy underwent a further reorientation in 1986, when exchange rate stability became the overriding goal. The krone was pegged to a trade-weighted basket of surrencies from 1986-90 and to the ECU from 1990-92. Although the krone was officially allowed to float following the delinking from the ECU in December 1992, the authorities maintained their emphasis on exchange rate stability. This emphasis on exchange rate stability was formalized in new guidelines for monetary policy issued by the Ministry of Finance to Norges Bank in May 1994.

\section{Monetary and exchange rate developments}

From its adoption in 1986, the credibility of Norway's fixed exchange rate policy gradually strengthened, as witnessed by the gradual narrowing of interest rate differentials vis-a-vis European currencies, in particular Germany (Chart 6). Furthermore, in marked contrast to the Swedish krona and the Finnish markka, the depreciation of the krone following its delinking from the ECU was quite limited (Chart 7).

\section{a. Exchange rate developments}

Immediately after the delinking from the ECU, the krone depreciated by somewhat more than 5 percent. However, in the first few months of 1993 the krone strengthened by around 2 percent, despite large purchases of foreign exchange by Norges Bank and reductions in official interest rates. The krone was unaffected by the currency pressures that preceded the widening of ERM fluctuation bands in the late summer of 1993. From mid-1993 to mid1994, the exchange rate of the krone remained fairly stable, albeit around a gently downward moving trend. By late sumer 1994, the exchange rate had declined to about its level immediately following the delinking from the ECU. The krone came under some pressure in the fall of 1994 in connection with the cycle of EU referenda in Finland, Sweden, and finally, Norway itself. However, once the result of the final referendum was in the exchange rate again strengthened. In January 1995, the exchange rate of the krone was about 4 percent below its central rate against the ECU prior to the delinking.

Because exchange rate policy has in recent years been oriented towards stability against the ECU, the (trade-weighted) nominal effective exchange rate has become more unstable than it was during the period 1986-90, when

1/ Prepared by Birgir Arnason. 
the exchange rate was pegged to a trade-weighted basket. The same applies to the real effective exchange rate (based on relative normalized unit labor costs). The real exchange generally depreciated from mid-1992 and into early 1994 but since then it has appreciated, largely because of the depreciation of the US dollar.

\section{b. Interest rate developments}

From 1986-92, interest rate developments in Norway were characterized by gradually declining interest rate differentials with respect to European countries, particularly Germany. In early 1987 three-month money market rates in Norway were about 12 percentage points higher than in Germany but in the summer of 1992 were only 50-100 basis points higher. The interest rate differential on the long end vis-a-vis Germany also narrowed, going from 8 percentage points in early 1987 to 150-200 basis points in the summer of 1992 for long-term government bonds. Official interest rates were raised sharply in the fall of 1992 in defense of the krone, with the result that on both the short and the long end interest rate differentials against Germany widened again.

Norwegian interest rates declined sharply in the course of 1993. From early 1993 to early 1994, short term rates declined by about 5 percentage points, to close to 5 percent. Similarly, long term rates declined by about 4 percentage points in 1993, dipping below 5 percent in early 1994. Through most of 1993 and into 1994, Norwegian interest rates were below German rates at both ends of the yield curve.

In 1994 Norwegian interest rates, especially short-term rates, were generally on an upward trend, reflecting to some extent movements in international interest rates. However, the rise in the short-term rate was particularly pronounced, leading to a widening of the differential with Germany to close to 200 basis points and was, at least partly, the result of uncertainty associated with the the Norwegian EU referendum in late November. Immediately following the referendum, short term rates again declined and in January 1995, at 5.8 percent, were about 70 basis points higher than in Germany. Long term rates had risen to about 8.2 percent, or about 60 basis points above German long rates.

Despite a substantial movement in money market rates in 1994, official overnight lending and deposit rates remained unchanged from February, at 6.75 percent and 4.75 percent, respectively.

\section{c. Developments in the monetary aggregates}

In recent years the development of monetary aggregates has been subdued. Through 1992 the money supply (M2) rose by 7.3 percent while the uptake of credit from both domestic and foreign sources declined by 1 percent. In the course of 1993, the expansion of the money supply slowed so that by December the twelve-month increase amounted to only 0.5 percent and the uptake of credit continued on a downward trend with the twelve-month 


\section{INTEREST RATE DEVELOPMENTS}
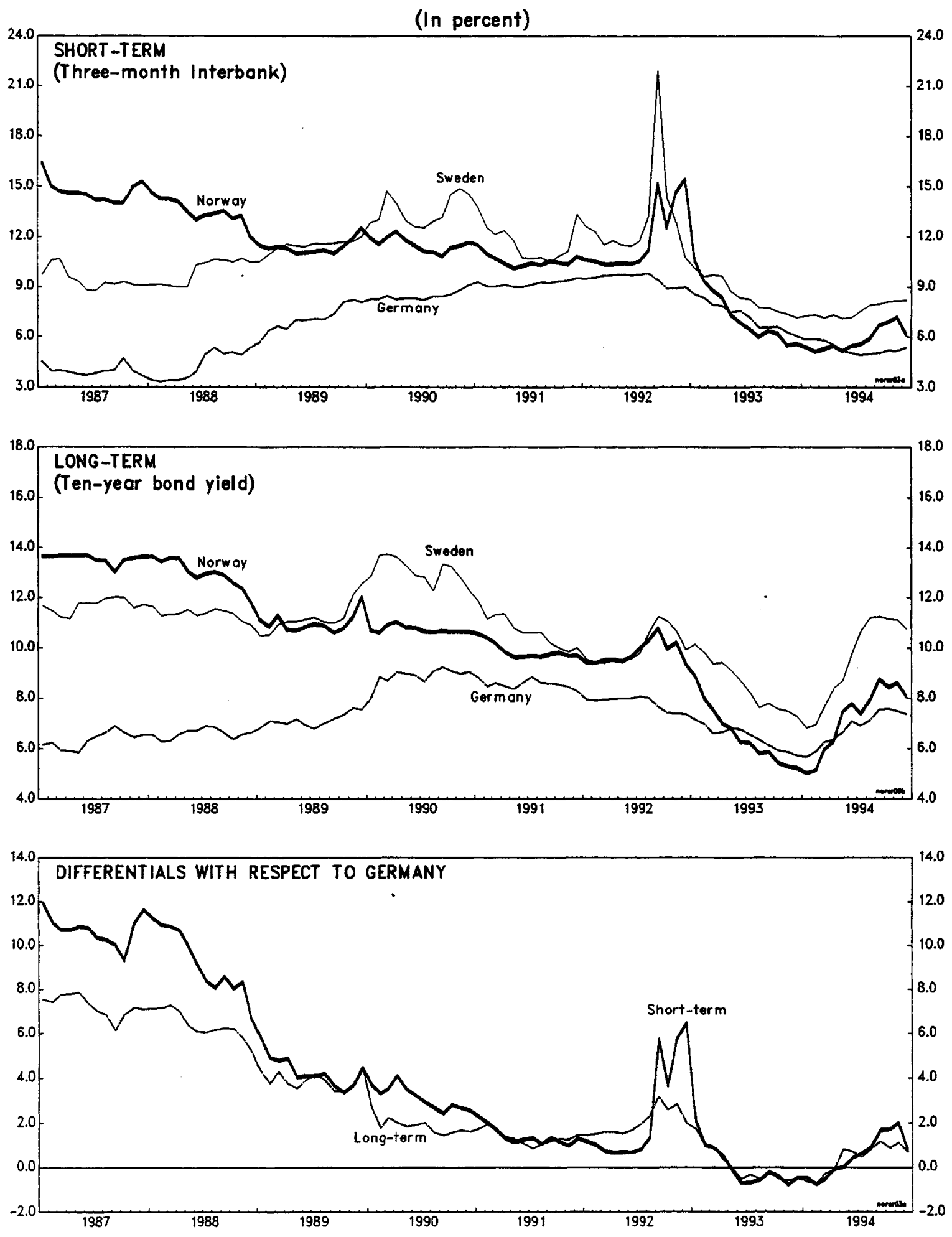

Sources: IMF, International Financial Statistics; Reseorch Deportment. 


\section{EXCHANGE RATE DEVELOPMENTS}
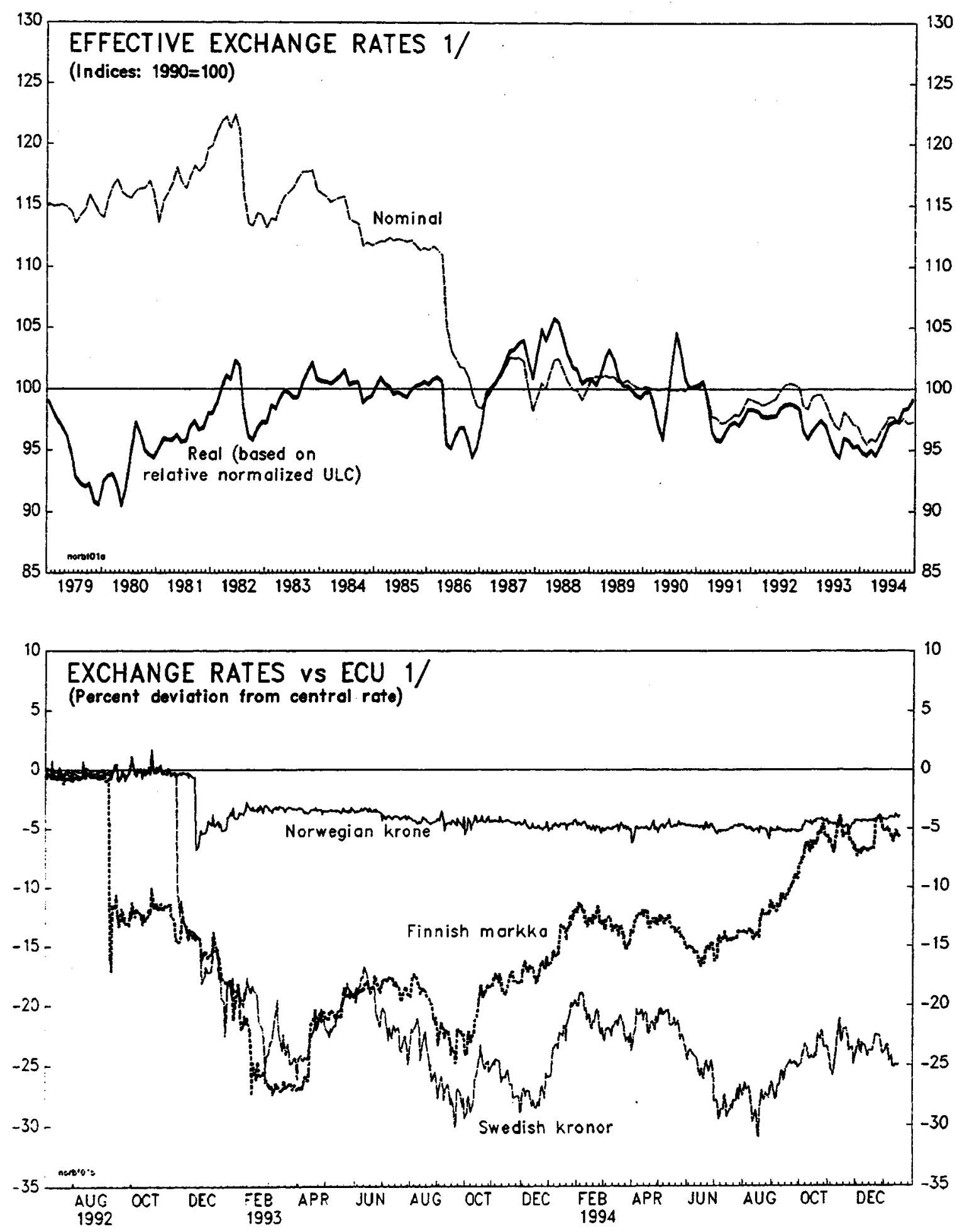

Solrces: IMF, International Financial Statistics; Treasurer's Department.

1/ An upwerd movement indicotes appreciation. 
decline in December at 0.5 percent. The rate of money supply expansion quickened in 1994, reaching a twelve-month rate of increase of 7.5 percent in September, while there were few signs of an increase in the uptake of credit.

\section{d. Developments in the external reserves}

Norges Bank intervened heavily in defense of the krone in the latter half of 1992. In net terms, Norges Bank sold foreign exchange for Nkr 50 billion from August through December, equivalent to more than 60 percent of of the Bank's international reserves. Nevertheless, at the end of 1992 the reserves were slightly larger than at the beginning of the year, having been replenished through swap arrangements, foreign borrowing and valuation adjustments. At Nkr 85 billion, they were equivalent to around 4 months worth of imports of goods and non-factor services.

In the face of large capital inflows during the first half of 1993, Norges Bank purchased foreign exchange in greater amounts than it had sold in 1992, but during the second half of the year the Bank's interventions in the foreign exchange market were very limited. By the end of 1993, the international reserves had risen to $\mathrm{NKr} 155$ billion, or the equivalent of 7 months of imports of goods and non-factor services.

The foreign exchange market was relatively calm during the first half of 1994. For a brief period in July, Norges Bank sold forelgn currency as the krone weakened because of pressure on the Swedish krona. During the fall, the foreign exchange market became somewhat unsettled and Norges Bank both sold and bought forelgn exchange in order to smooth the market. At times, capital inflows--linked to the inclusion of Norwegian government bonds in two international bond indices--put upward pressure on the exchange rate, which Norges Bank sought to resist through the purchase of foreign exchange. At other times, general nervousness about the outcome of the EU referenda in Norway, Sweden and Finland led to pressures on the krone, which the Bank sought to ease through the sale of foreign exchange. Overall, these operations were quite limited, with the Bank's net sale of foreign exchange amounting to $\mathrm{NKr} 3$ billion in the period from early september to early December. Through the first eleven months of 1994, Norges Bank net sale of foreign exchange amounted to slightly more than NKr 2 billion while the overall level of international reserves declined by about

Nkr 10 billion--because of valuation effects--but remained comfortably well above 6 months worth of imports of goods and non-factor services.

\section{Monetary policy guidelines}

When the krone was delinked from the ECU in late 1992, the authorities announced their intention to return to a fixed exchange rate as soon as international conditions permitted on the expectation that fixed exchange rates would again become the norm across Europe. With the widening of the ERM fluctuation bands in the summer of 1993, it became apparent that the return to fixed exchange rates was not imminent, and Norges Bank indicated 
to the Government a need for clearer guldelines on a long-term objective for monetary policy under the conditions of generally floating exchange rates. The Bank argued the best contribution monetary policy could make to the main objectives of sustainable economic growth and full employment was to secure low price and wage inflation. Having reviewed international experience with the conduct of monetary policy under floating exchange rates and its relevance to Norwegian conditions, the Government announced new monetary policy guidelines, on the basis of recommendations from Norges Bank, in connection with the Revised National Budget in May 1994. I

According to these guidelines monetary and exchange rate policy was to be aimed at maintaining the krone exchange rate against European currencies at about its then current level. Furthermore, Norges Bank would seek to avoid wide short-term fluctuations in the exchange rate. However, the Bank would not be committed to defending any particular parities and would not use instruments to the same extent, i.e., with regard to purchases in support of the krone and short term increases in interest rates, to defend the krone as under the fixed exchange rate, but the instruments would be oriented with the aim of returning the exchange rate over time to its initial level. In effect these new guidelines were a formalization of the practice since the delinking from the ECU.

\section{Changes in exchange and trade regulations}

The European Economic Area agreement between five of the EFTA countries, including Norway, and the EU went into effect on January 1 , 1994. 2/ The EEA extends to its non-EU participants, EU legislation and regulations concerning the internal market, in particular the free movement of goods, capital, services and people across borders. Furthermore, the competition policies of the non-EU participants are aligned with those of the EU. Among the more important areas not included in EEA are agriculture and economic and monetary policy cooperation. In a referendum on November 28, 1994, Norway rejected in a referendum to join the EU, whereas previously Austria, Finland and Sweden had approved joining. In early 1995, the remaining non-EU participants in the EEA-Norway and Iceland--decIded in concert with the EU that the EEA will be maintained despite the significant weakening of the EFTA pillar.

1 See Norges Bank, Monetary Policy Under a Floating Exchange Rare. Submission to the Ministry of Finance, April 1994. Among the experiences examined were those of Sweden, Finland and New Zealand, countrles whlch have adopted explicit low inflation targets. In implicitly rejecting direct inflation targeting, the Norwegian authorities argued that Norway's long tradition with fixed exchange rates made continued emphasis on exchange rate stability desirable. In any case, over the long run emphasis on exchange rate stability would be fully consistent with low inflation.

2/ The five countries were Austria, Finland, Iceland and Sweden. Switzerland rejected in a referendum to participate in the EEA and Liechtenstein is yet to participate. 


\section{Official development assistance}

Norway continues to be close to the top on the list of official development assistance (ODA) donors. In 1994, total ODA amounted to almost Nkr 8 billion, or the equivalent of around 1 percent of GDP.

Table 9: Norway's Official Development Assistance (millions of kroner)

$\begin{array}{lrrr} & 1992 & 1993 & 1994 \\ \text { Bilateral grants } & & & \\ \text { Bilateral loans } & 4,734 & 4,362 & 5,230 \\ \text { Multilateral ODA } & 29 & 36 & 36 \\ \text { Administrative costs } & 2,873 & 2,522 & 2,444 \\ \quad \begin{array}{c}\text { Total ODA } \\ \text { Total ODA }\end{array} & 285 & 284 & 284 \\ \quad \text { percent of GDP } & 7,921 & 7,203 & 7,994 \\ & 1.12 & 1.00 & 1.04\end{array}$

Source: OECD. 


\section{Estimates of Mainland Output Gap and NAIRU 1/}

\section{Introduction}

This appendix presents estimates of the output gap and the structural rate of unemployment (NAIRU) for Norway's mainland economy. The goal is, on the one hand, to assess the cyclical position of the mainland economy and, on the other hand, to provide an input to the estimation of structural government balances provided in Appendix II.

Three alternative methods are used here--the segmented trend, the HP filter and the production function approach. As discussed in Sections 2-4, each of these methods is based on distinct assumptions and so is 1ikely to yield distinct estimates. However, given the lack of consensus about the superiority of any particular method, $2 /$ it is important to compare the actual results from each of these approaches; the more similar they are, the greater the reliability of the respective estimates. In the case of Norway, it is shown that the different methods lead to similar inferences about the magnitudes of the mainland output gap and the NAIRU during 1985-95.

\section{Segmented trend estimates}

The segmented trend method assumes that potential output evolves along a fixed growth trend which is only shifted by infrequent major shocks. Support for this view stems from the stylized fact that OECD economies displayed a relatively stable output growth and unemployment rate for over two decades before being disrupted by the oil shocks of the 1970 s and other structural changes which set these economies onto a lower growth path. From this perspective, potential output can be simply estimated as the fitted value of a regression of actual output on a time trend broken in 1973 and in the post-1979 period. 3 /

This approach yields estimates for the mainland output gap reported in Table 10. It indicates that the level of actual output was 6.7 percent above potential in the peak of cyclical upswing of the mid-1980s, then falling to nearly 4 percent below potential in 1991. As the recovery of the

\section{1/ Prepared by Luis Catão.}

2/ See, for instance, the OECD Secretariat's draft report to the Working Group on Short-Term Economic Prospects, Estimating Potential Output, Output Gaps and Structural Budget Balances, and Barrell et al., The Cyclical Adjustment of Budget Balances, A report for the European Commission, June 1994.

3/ Care should be taken in the choice of the end points, which should be comparable in terms of the economy's position in the business cycle. That is, if the starting point of the series corresponds to a business cycle peak (trough), the last observation should also correspond to a peak (trough) year. 
early 1990 s gained momentum, however, this gap has narrowed substantially-. to just over 1 percent during 1994. Under the current projection of mainland GDP growth of around 3 percent in 1995, the output gap would then be closed by the end of 1995 .

Table 10. Estimates of Mainland Output Gap (percentage of real mainland GDP) $1 / 2 /$

\section{Segmented} trend $\underline{3}$
4.7
6.7
6.2
2.7
$-1.2$
$-1.7$
$-3.9$
$-3.5$
$-3.2$
$-1.3$
0.0

HP filter

$$
3.5
$$

5.2

4.8

1.7

$-1.8$

$-1.9$

$-3.7$

$-3.0$

$-2.6$

$-0.9$

0.0
Production

function

3.9

5.4

4.7

1.3

$-2.2$

$-2.3$

$-4.0$

$-3.2$

$-2.6$

$-1.0$

0.0

Source: IMF staff estimates.

1 Estimates based on annual data from 1973.

2/ A negative sign means output is below potential.

3 Based on fitted values of the following ols regression:

$$
\begin{aligned}
\text { In } \mathrm{GDP}_{t}+\mathrm{b}_{0}+\mathrm{b}_{1} * \text { TREND }+b_{2} D 79+b_{3} * \mathrm{D} 79 * \text { TREND }+\epsilon_{t} \\
\text { where } \mathrm{D} 79=0 \text { for } \mathrm{T} \leq 1979 \\
\mathrm{D} 79=1 \text { for } \mathrm{T}>1979
\end{aligned}
$$

Segmented trend estimates of the NAIRU are reported in Table 11. They point to a rise in the structural rate of unemployment from around 3 percent in the mid-1980s to nearly 5 percent in 1993-94.

\section{HP filter estimates}

The use of the Hip filter is motivated by two important limitations of the segmented trend approach. First, the latter assumes that breaks in the growth rate of potential output or unemployment are infrequent and abrupt, taking place at a specific point in time. Secondly, the choice of a turning point is decided on the basis of a priori information, rather than being endogenously determined by the model. This opens the possibility of judgement biases in the selection of turning point dates.

The HP filter provides a solution for both problems. It sets out an algorithm which endogenously determines the trend path of the variable and 
Table 11. Estimates of NAIRU (percent of labor force)

HP filter

1985

1986

1987

1988

1989

1990

1991

1992

1993

1994

1995
3.0

3.3

3.6

3.9

4.2

4.5

4.7

4.9

5.0

5.1

5.1
Segmented Trend

2.9

3.0

3.2

3.4

3.6

3.8

4.1

4.3

4.6

4.8

5.1

Source: IMF staff estimates.

allows this path to take a variety of different shapes. $1 /$ This encompasses the simple case of a purely linear trend as well as more complex non-linear trend shapes resulting from hysteresis effects. In addition, the HP filter has the advantage that, due to its symmetric form, it cannot distort the tining of events: a peak (trough) in the estimated trend will always coincide with a peak (trough) in actual output. 2 /

Table 10 reports the results for mainland output. These point to a decline in the output gap from 5 percent above potential in 1986-87 to 3.7 percent below potential in 1991. This gap has been gradually eroded during the recovery which is under way. At the end of 1994, actual output stood at 0.9 percent below potential, a gap which should be eliminated

1/ The HP filter algorithm minimizes the following loss-function associated with deviations of the variable $Y$ from its trend ( $Y *)$ :

$$
\frac{1}{T} \sum_{t=1}^{T}\left(y_{t}-y_{t}^{*}\right)^{2}+\frac{\lambda}{T} \sum_{t=2}^{T-1}\left[\left(y_{t+1}^{*}-y_{t}^{*}\right)-\left(y_{t}^{*}-y_{t-1}^{*}\right)\right]^{2}
$$

where $\alpha$ is a parameter which determines the degree of smoothness of the filter and usually set as 1,600 in most practical applications.

2/ As in the case of segmented trend fitting, however, care should be taken to select the sample series so that its end points are roughly comparable. Ideally, the series should start and end at points which normally correspond to either business cycle peaks or business cycle troughs. 
during 1995, in 1ight of current growth projections. These magnitudes are only slightly below those yielded by the segmented trend method. If

The results for the unemployment rate series are provided in Table 11. They point to a substantial rise in the NAIRU--from 3 percent in 1985 to 5.1 percent in 1994-95, a result which is also in line with that provided by the segmented trend approach.

\section{Production function estimates}

In contrast with the segmented trend and the HP filter methods, the production function approach derives production trends from input data. This can be advantageous insofar as it incorporates valuable information on the growth of the labor force and of the capital stock, variables which have a direct bearing on the determination of potential output. In addition, this method encourages reconciliation of projections of labor force and investment growth with those of output, thus providing a further consistency check for such projections.

The method can be briefly outlined as follows. Given the net capital stock, the employable labor force and total factor productivity, potential output is estimated by a two factor log-linear Cobb-Douglas production function:

$$
Y=A L^{\alpha} K^{(1-\alpha)} e^{T F P}
$$

where A stands for the output level at the base year, $L$ : is employable labor force, $\mathrm{K}$ is the net capital stock and TFP is total factor productivity. The parameter $\alpha$ stands for the (average) wage share in national incone.

Estimation proceeds in two main stages. The first consists of estimating changes in the employable labor force and TFP on the basfs of actual data. Changes in the employable labor force were computed by multiplying the average rate of growth in labor force between 1979 and 1994 by changes in the NAIRU as estimated by the HP filter. Changes in IFP were obtained as a residual from the production function.: As in other countries, however, TFP for mainland Norway appeared to be highly sensitive to the business cycle and so needed to be smoothed out to yield "normal" rates of factor productivity growth. This was done by running the HP fllter through the series.

The second stage consists of forecasting the growth of the labor force and capital stock. The growth of the labor force for 1995 was estinated on the basis of official forecasts at 0.9 percent. The capital stock forecast was obtained by extrapolating the stock at the end of 1994 using the

1 This is expected since the segmented trend approach assumes a fixed growth trend over the post-1979 period while the HP trend, by construction, tracks the actual data more closely. 
official forecast of 9.4 percent growth in fixed capital formation in 1995 discounted for an annual rate of capital depreclation of 3 percent. 1

Plugging these growth estimates of $N, K$ and TFP into the production function equation and setting $\alpha=0.672 /$ gives the rate of growth of potential output through 1995. To calculate the level of potential output, it was assumed that the economy was operating at potential in 1984 . 3 / The level of potential output for subsequent years was then obtained by extrapolating the output level for 1984 using the estimated annual growth rates of potential output through 1995 .

Table 10 reports estimates of the mainland output gap using the production function approach. These indicate that actual output reached a trough in 1991 --when it stood at about 4 percentage points below potential-. but since then this gap has narrowed considerably. By the end of 1994 the gap was down to 1 percentage point and is due to be closed during 1995. These results are similar to those yielded by the previous methods.

\section{Conclusions}

This appendix has used the segmented trend, the HP filter and the production function approach to estimate the mainland output gap. In contrast with the case of some other countries, these different methods produced very similar results for Norway. They indicate that at the trough of the last recession, in 1991, mainland output stood at about 4 percent below potential but that this gap has narrowed considerably since then. At the end of 1994, it was down to around 1 percent. Under the assumption of 3 percent growth for mainland real GDP during 1995, all three methods indicate that the output gap will be closed by the end of that year.

The segmented trend approach and the HP filter were also used to estimate the structural rate of unemployment (NAIRU) in Norway. In Iine with the prevalling view, these estimates point to a significant increase in the NAIRU over the last ten years. 4/ Both methods indicate that the NAIRU has risen from 3 percent in 1985-86 to around 5 percent in 1993-94 and is likely to remain at this level during 1995 .

1) This annual rate of depreciation underlies the estimates of net capital stock provided in Norway's national accounts. It can be calculated by running a regression of current net capital stiock on fixed capital formation and lagged capital stock.

2/ This corresponds to the average share of labor earnings in national income since the mid-1970s.

3/ This assumption is corroborated by HP filter estimates which point to an output gap of less than 0.1 percent for 1984 .

4/ For a detailed account of the factors that underlie the increase in the Norwegian NAIRU, see OECD Economic Surveys; Norway 1994, OECD, 1994. 


\section{The General Government Structural Balance 1988-95 I/}

\section{Introduction}

During the late 1980s and early 1990s, the finances of the public sector in Norway deteriorated sharply. The overall general government balance, for example, went from a surplus of 6 percent of mainland GDP in 1988 to a deficit of more than $51 / 2$ percent in 1993. Other measures of fiscal balance showed a similar deterioration over this period. This deterioration in the public sector finances coincided with a period of relative stagnation in the mainland econony, which led to some cyclical weakening of the public finances. However, during this period the Government also pursued activist fiscal policies in order to support activity and employment. An important question is, therefore, the extent to which the weakening of the fiscal balances was structural in nature. This note presents preliminary estimates of the deterioration in the structural component of the general government balance in Norway over the period 1988-93 along with projections for 1994 and 1995, based on methodology commonly employed in the Fund for this purpose. 2/

\section{Methodology}

The structural budget balance is defined as the balance between revenue and expenditure that would result if the economy were at its full potential. Estimating the structural balance (or, the cyclically adjusted balance), therefore, essentially consists of estimating the levels of revenue and expenditure that would prevail. were the economy at its potential. The structural balance, $B_{s}$, is given by:

$$
B_{s}=R_{s}-E_{s}
$$

where, $R_{S}$ is revenue at potential and $E_{S}$ is expenditure at potential.

In turn, revenue at potential is given by:

$$
R_{S}=R_{a c} *\left(1-\varepsilon_{R} * G A P\right)+R_{a 0}
$$

where $R_{a c}$ and $R_{a o}$ are cyclically sensitive revenue and other revenue, respectively, $\varepsilon_{R}$ is the elasticity of cyclically sensitive revenue with respect to output, and GAP is the output gap.

1) Prepared by Birgir Arnason and Luis Catão.

2/ For a discussion of the Fund's approach to measuring structural fiscal balances see, for example, Annex I (Structural Budget Indicators for the Major Industrialized Countries) to the Fund's World Economic Outlook, October 1993, or O'Callaghan et al., Recent Fiscal Developments in the European Countries of the G-7, IMF Paper on Policy Analysis and Assessment, July 1994. 
For simplicity, it is assumed that unemployment benefits are the only cyclically sensitive expenditure component. Expenditure at potential is, therefore, given by:

$$
E_{s}=E_{a}-U B+U B *\left(U_{N A I R U / U a}\right)
$$

where $E_{a}$ is actual expenditure, UB denotes actual unemployment benefits, $U_{\text {NAIRU }}$ is the unemployment rate at potential (the non-accelerating inflation rate of unemployment) and $U_{a}$ is the actual unemployment rate.

To apply this methodology, one first needs to separate expenditure and revenue, respectively, into their cyclically sensitive and non-sensitive components. Second, one needs estimates of the elasticity of revenue with respect to output, on the one hand, and, on the other, of the economy's natural rate of unemployment. Third, and most important, one needs estimates of the economy's cyclical position over time.

\section{Application to Norway}

In the case of Norway, it is necessary to make special allowances for the large petroleum sector, which can be impacted by different forces than the mainland economy and can, therefore, exhibit different cyclical behavior. Two simplifying steps have been taken to take account of the petroleum sector. First, the Government's tax revenue from the petroleum sector has been lumped with non-cyclical revenue (which, inter alia, includes all income from property, including from assets in the petroleum sector); I/ second, cyclically sensitive revenue has been related to the estimated output gap of the mainland economy rather than the output gap for the economy as a whole.

While a varlety of methods are avallable to obtain a time series for potential output and the output gap; here we use the results obtained using a production function approach described in Appendix I. The potential output series is shown in Chart.8. The mainland economy was significantly above potential in the mid-1980s, but fell below potential towards the end of the $1980 \mathrm{~s}$, a trend that continued into the $1990 \mathrm{~s}$. According to the estimates, the mainland economy went from being 1.3 percent above potential in 1988 to being 4.0 percent below potential in 1991. More recently the output gap has narrowed and, based on projections very similar to the most recent official forecasts for the mainland economy--growth of mainland output of 3.0 percent--the output gap will close by the end of 1995 .

Regression analysis has shown that the elasticity of cyclically sensitive revenue with respect to mainland output is very close to unity

1) This contrasts with the manner in which the authorities measure the fiscal impulse of a change in the state budget where special account is taken of oil-related developments. 


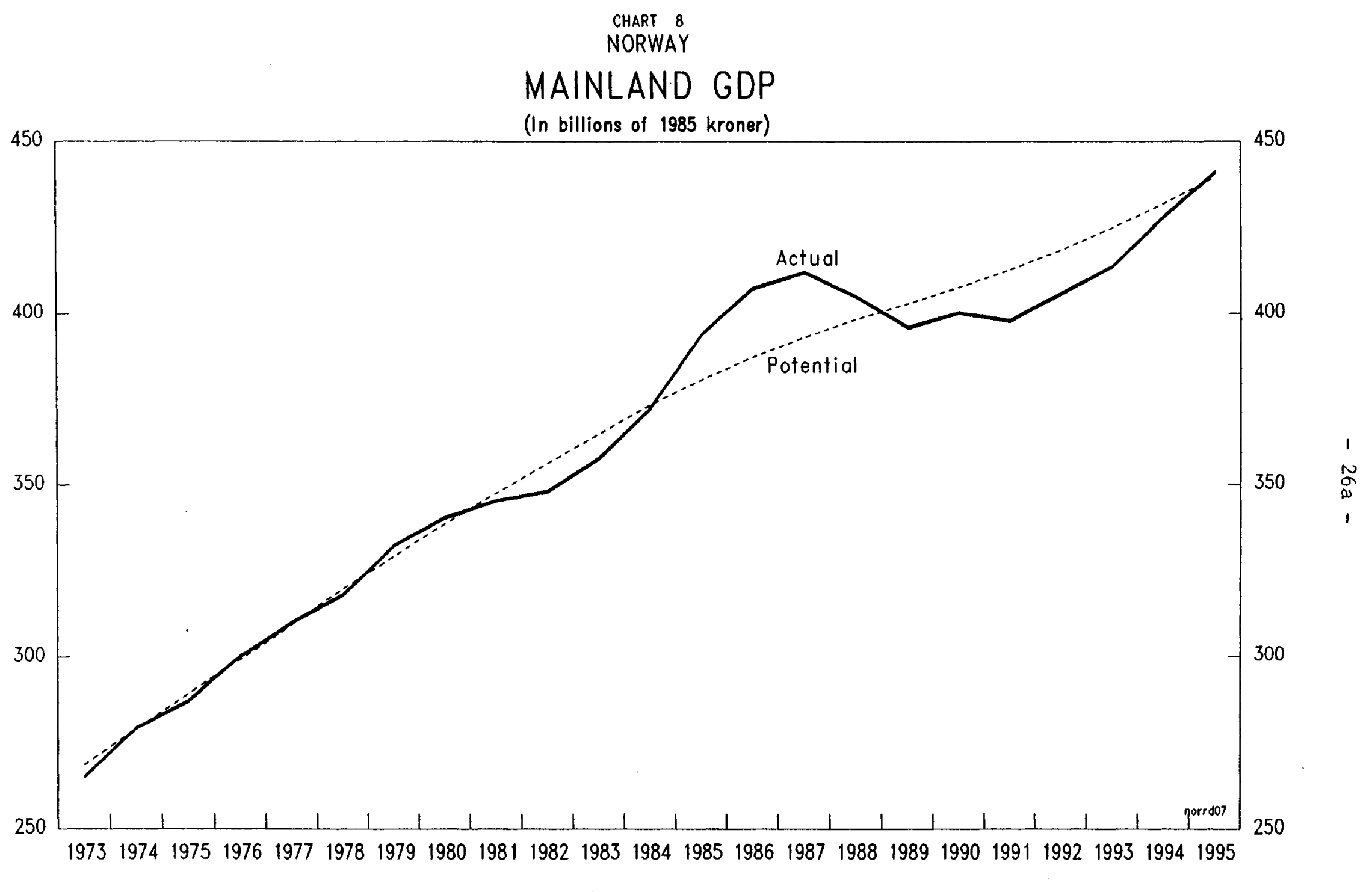

Sources: Dato provided by Norwegian authorities; and staff estimates. 
This page intentionally left blank

CInternational Monetary Fund. Not for Redistribution 
( 1.02 to be exact). This is not an unexpected result and conforms well with estimates of revenue elasticities in other countries with broadly similar tax structures to that of Norway. Furthermore, econometric tests showed that there were no structural breaks in the revenue series. 1/

As reported in Appendix I, the HP filtering method has also been used to obtain estimates of the NAIRU for Norway. 2/ The results are shown in Chart 9. As the HP filter fits a trend through the data and because the unemployment rate in Norway has generally risen in the recent period, the results confirm the general impression that the Norwegian NAIRU has risen in recent years, related, inter alia to the broadening of the unemployment benefits system having hysteresis effects. 3 / More specifically the estimates suggest that the NAIRU moved from 1-1 1/2 percent of the labor force in the $1970 \mathrm{~s}$, to $3-31 / 2$ percent in the mid-1980s, and to 5 percent in the early 1990s. This is a significantly higher estimate of the Norwegian NAIRU than reported, for example, by Jackman et al., which produced an estimate of $31 / 2$ percent of the labor force. 4/ However, their estimate was based on data prior to 1991, and thus does not take account of the high unemployment of 1991-93. On the other hand, it should be noted that because of end-point problems associated with the symetric structure of the HP filter, the very high estimates of the NAIRU for the most recent years could be overestimates. Under the growth assumptions mentioned above the reported unemployment rate should decline to very close to the NAIRU level of 5 percent in 1995. 5/

Combining the above considerations provides the estimates of the general government structural balance over the period 1988-95 shown in the tabulation below.

1 For example, the tests did not reveal a structural break in the revenue series associated with the tax reform of 1992 .

2f As with the output gap, a theoretically more satisfying approach exists. This would consist of using econometric analysis of data on wage and unemployment developments. Limitations on the avallable data preclude pursuing this approach at the present time.

3 For a detailed account of the factors underlying the hysteresis effects, see OECD Econonic Surveys: Norway 1994, OECD, 1994.

4/ Jackman, R., R. Layard and S.J. Nickell, Unemployment, 1991.

5/ Close to 3 percent of the labor force are currently engaged in active labor market programs. It is clear, however, that participation in a labor market scheme is to some extent a substitute for long-term unemployment. Perhaps only half of those engaged in these programs are actually employable. 
General Government Structural Balance 1988-95

(in percent of potential mainland GDP)

\begin{tabular}{|c|c|c|c|c|c|c|c|c|}
\hline & 1988 & 1989 & 1990 & 1991 & 1992 & 1993 & 1994 & 1995 \\
\hline $\begin{array}{l}\text { Total revenue } \\
\text { Total expenditure }\end{array}$ & $\begin{array}{l}62.6 \\
56.6\end{array}$ & $\begin{array}{l}63.5 \\
61.9\end{array}$ & $\begin{array}{l}66.7 \\
63.5\end{array}$ & $\begin{array}{l}64.9 \\
65.9\end{array}$ & $\begin{array}{l}64.4 \\
68.1\end{array}$ & $\begin{array}{l}64.4 \\
70.0\end{array}$ & $\begin{array}{l}66.4 \\
69.7\end{array}$ & $\begin{array}{l}65.3 \\
67.8\end{array}$ \\
\hline Overall balance & 6.0 & 1.7 & 3.2 & -1.1 & -3.7 & -5.6 & -3.7 & -2.5 \\
\hline $\begin{array}{l}\text { Cyclically adjusted } \\
\text { revenue } \\
\text { Cyclically adjusted } \\
\text { expenditure }\end{array}$ & 57.0 & 64.7 & 67.9 & 66.6 & $\begin{array}{l}66.0 \\
67: 8\end{array}$ & 65.7 & $\begin{array}{l}66.6 \\
69.6\end{array}$ & $\begin{array}{l}65.3 \\
67.8\end{array}$ \\
\hline Structural balance & 4.9 & 2.8 & 4.5 & 1.0 & -2.8 & -4.0 & -3.0 & -2.5 \\
\hline Output gap 1 & 1.3 & -2.2 & -2.3 & -4.0 & -3.2 & -2.6 & -1.0 & 0.0 \\
\hline
\end{tabular}

1/ A positive number indicates that output is above potential.

According to these estimates the structural balance went from a surplus of just under 5 percent of potential mainland GDP in 1988 to a deficit of 4 percent in 1993, representing a deterioration in the structural balance of almost 9 percent of potential mainland GDP. As the actual balance deteriorated by just over $11.1 / 2$ percent of potential mainland GDP, the analysis indicates that the deterioration in the structural balance accounted for around three-fourths of the deterioration in the overall balance over the period 1988-93. The deterioration in the structural balance is entirely accounted for by increased expenditure, both on public consumption and transfers to households. Between 1988 and 1993, cyclically adjusted expenditure of the general government rose from 57 percent of potential mainland GDP to almost 70 percent. During the same perlod. cyclically adjusted revenue in fact rose from just under 62 percent of potential mainland output to close to 66 percent.

While the Norwegian authorities do not present official estimates of the general government structural balance, they do present an estimate of the fiscal impulse of changes in the state budget, corrected for cyclical effects, the petroleum sector and changes in interest rates. The sum of the fiscal impulse over a number of years can be interpreted as providing an estimate of changes in the state's (or, central government's) structural balance over the period. With the central government dominating general government, and local governments in broad fiscal balance in recent years, the change in the state's structural balance in recent years should.assuming no net change in the net petroleum related balance--approximate fairly closely the change in the general government structural balance. 
CHART 9

NORWAY

\section{UNEMPLOYMENT}

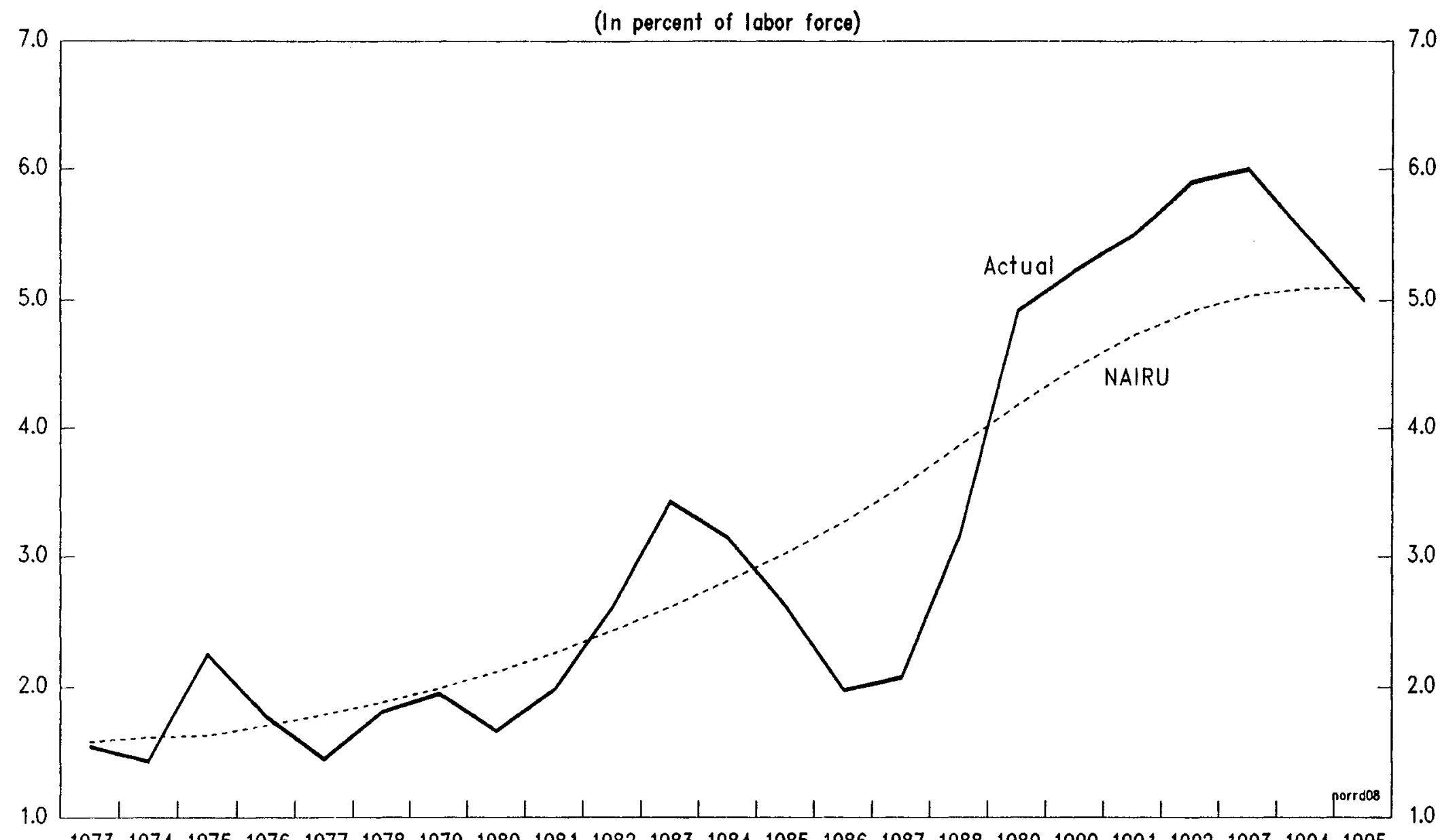

19731974197519761977197819791980198119821983198419851986198719881989199019911992199319941995

Sources: Dota provided by Norwegian outhorities; and staff estimates. 
This page intentionally left blank

CInternational Monetary Fund. Not for Redistribution 
According to the National Budget for $1995 \mathrm{l} /$, the total fiscal impulse emanating from the state budget over the period 1989-1993 amounted to close to 8 percent of mainland GDP $2 /$, a figure only marginally smaller than the staff's estimate of a deterioration in the general government structural balance of 9 percent of potential mainland GDP over 1988-93, reported above.

Staff projections based on the final 1995 budget indicate that in 1995, when output will again have reached potential, the structural balance will still be in deficit of $21 / 2$ percent of mainland GDP, a situation which contrasts sharply with the late 1980 s when the structural balance was in considerable surplus.

1) Ministry of Finance, October 1994.

2/ As mainland GDP accounts for around 85 percent of total GDP, this is equivalent to 7 percent of total GDP. 


\section{The Norweglan Petroleum Sector 1/}

\section{Introduction}

Since oil production first commenced on the Norwegian continental shelf in the North Sea in 1971, Norway's petroleum sector has expanded rapidly. By 1993, Norway had become the fourth largest oll exporter in the world. The expansion of the petroleum sector has had a number of important consequences for the Norwegian economy, some of which have been adverse. Thus, the expansion of the petroleum sector in the 1970 s and early 1980s contributed to the weakening of Norway's manufacturing industry through the process commonly known as the "Dutch disease" in which an increase in income from petroleum production erodes international competitiveness. 2/ Also, the large external shock associated with the collapse in oil prices in 1986 magnified the boom-bust cycle that followed excessive credit expansion associated with financial deregulation and generous tax treatment of interest payments in the early 1980s. Overall however, the petroleum sector has provided clear net benefits to the Norwegian economy, including greater national income and treasury revenue. As a result, Norway has been able to avoid some of the public sector and external imbalances that other Nordic countries, especially Sweden and Finland, have had to tackle in recent years. The question, nevertheless, remains whether the expansion of the petroleum sector and the consumption of its proceeds has been sustainable from a wealth management perspective.

This appendix describes the Norwegian petroleum sector and its impact on the Norwegian economy. The first section below discusses Norwegian production of $0 i 1$ and gas to date and current estimates of Norwegian petroleum resources, as well as a profile of future oil and gas production prepared by the authorities. The following section describes the macroeconomic impact of the development of the petroleum sector. The penultimate section describes the organization of state involvement in the petroleum sector and the importance the sector has for the public finances. The final section presents some estimates of the value of the petroleum wealth as well as of the permanent income from oil and gas.

\section{Petroleum resources and production}

Norwegian oil production commenced in 1971 and gas production six years later. Gas production rose rapidly--in a span of $3-4$ years--to about its current level, whereas oil production increased gradually through the 1970 s and into the 1980s; however, since the mid-1980s, oil production has risen rapidly (Chart 10). In 1993, oil production reached 114.5 million tons of

1/ Prepared by Birgir Arnason.

2/ The "Dutch Disease" process in the case of Norway is explored in more detail in Appendix IV. 


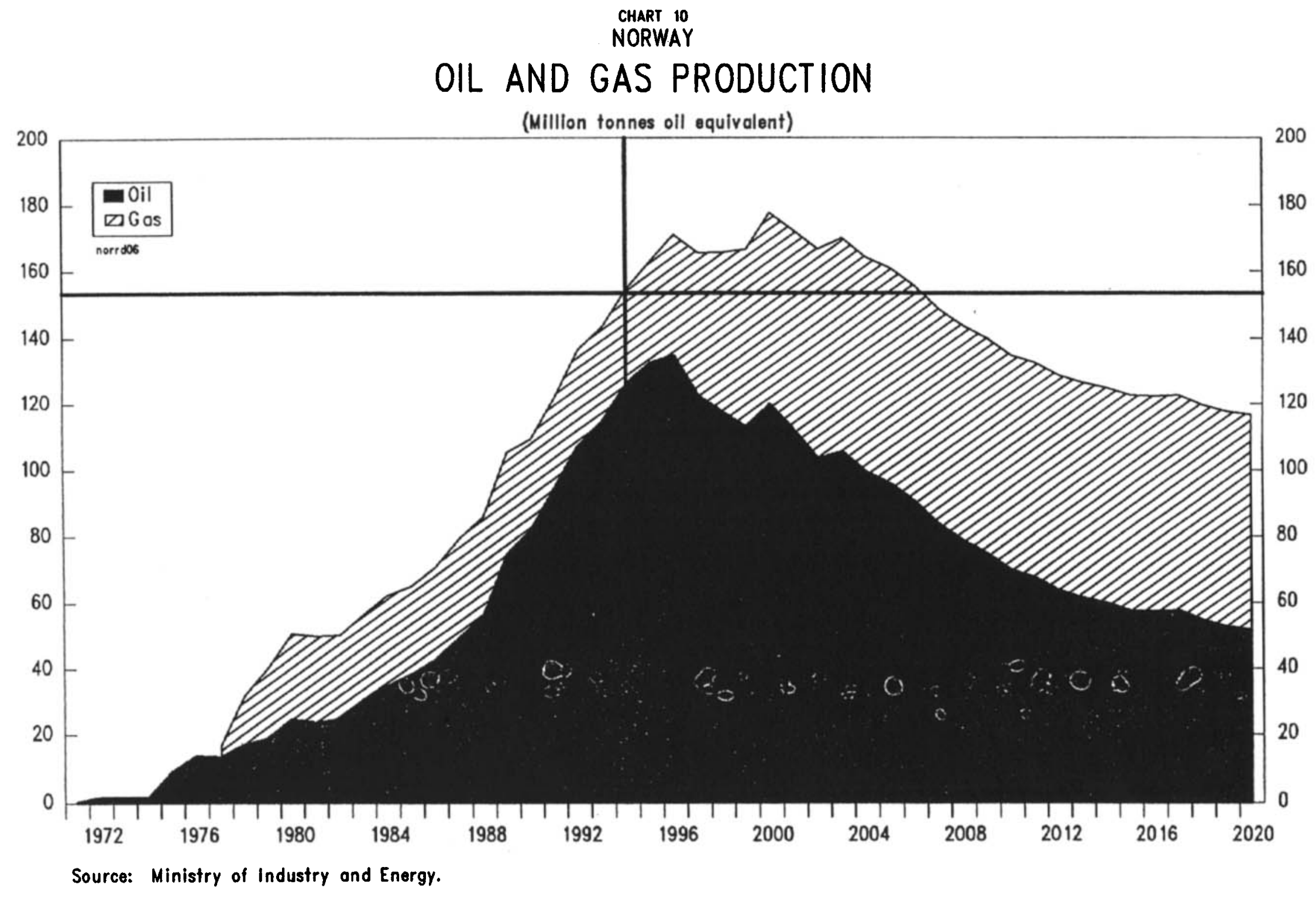

CInternational Monetary Fund. Not for Redistribution 
This page intentionally left blank

CInternational Monetary Fund. Not for Redistribution 
oil equivalent (toe) 1 / compared with 24.5 million toe in 1980 , corresponding to an annual average growth rate of almost 13 percent. On the other hand, gas production in 1993 was 28.9 million toe compared with 26 million toe in 1980 . Total petroleum production in 1993, thus, amounted to 143.4 million toe, of which oil accounted for 80 percent and gas the remaining 20 percent.

Cumulative Norwegian oil and gas production from the early 1970 s through 1993 amounted to 1.3 billion toe, of which oil accounted for close to 70 percent and gas, 30 percent. This can be compared with end-1993 estimates of remaining discovered petroleum resources and commercially proven reserves presented in the tabulation below. $2 /$

\section{Norway's Remaining Petroleum Resources and Reserves in 1993} (million tons of oil equivalent)

$\begin{array}{crrr} & 011 & \text { Gas } & \text { Total } \\ \text { North Sea resources } & 1,910 & 2,200 & 4,110 \\ \text { of which: reserves } & 1,170 & 1,860 & 3,030 \\ \text { Norwegian Sea resources } & 340 & 330 & 670 \\ \text { of which: reserves } & 190 & 150 & 340 \\ \text { Barents Sea resources } & 20 & 260 & 280 \\ \text { of which: reserves } & -- & -- & - \\ \text { Total resources } & 2,270 & 2,790 & 5,060 \\ \text { of which: reserves } & 1,360 & 2,010 & 3,370\end{array}$

Source: Ministry of Energy and Industry.

Total discovered oil and gas resources at the end of 1993 are estimated at just above 5 billion toe, or around four times the cumulative production to date. Estimates of proven reserves are put at almost 3.4 billion toe, or almost three times production to date. Particularly noteworthy in the tabulation is that gas accounts for considerably more than half of both total petroleum resources and reserves. While hydrocarbons have been discovered in three areas of the Norwegian continental shelf--in the North Sea south of Norway, in the Norwegian Sea to the west and in the Barents Sea north of the country--the bulk of discoveries has been made in the North Sea, which is also the only area in which petroleum extraction has commenced.

1/ 1 million tons of oil equivalent corresponds to a production level of about 20.5 thousand barrels of oil per day. The 1993 oil production level was, therefore, equivalent to about 2.3 million barrels per day.

2/ These are the most recent estimates available. Proven reserves are that part of discovered resources that can be commercially extracted given current prices and technology. 
These estimates of petroleum resources and reserves are, of course, highly uncertain. However, the clear tendency in recent years has been for the estimates of remaining resources and reserves to rise, implying that new discoveries, as well as prospects for enhanced recovery, have in any given year generally exceeded the annual offtake of oil and gas. At 1993 production levels, Norway's estimated oil reserves and resources would last for 12 years and 20 years, respectively, whereas the corresponding numbers for gas are 70 years and almost 100 years.

It is clear that in relation to current production levels gas resources far exceed oil resources. This is reflected in projections of future production of oil and gas prepared by the Norwegian Ministry of Industry and Energy (see Chart 10). Oil production is projected to peak in 1996-97 at close to 135 million toe per year and gradually decline thereafter. By the turn of the century annual oll production will have declined to around 120 million toe, to close to 70 million toe in 2010 and to 50 million toe in 2020. Gas production, on the other hand, is projected to increase sharply over the next decade, going from under 30 million toe in 1993 to 65 million toe per year after 2005. As a result, combined oil and gas production is projected to increase for a few more years and then plateau well into the next century, and not fall below current production levels until around 2010. In 2020, oil and gas production is projected to have declined to about its 1990 level.

\section{The macroeconomic impact of the petroleum sector}

The tabulation below provides some key indicators of the impact on the Norwegian economy of the expansion of the petroleum sector.

Macroeconomic Impact of the Petroleum sector (percent of the economy total)

$\begin{array}{lrrrrrr} & 1975 & 1980 & 1985 & 1990 & 1993 & 1994 \\ \text { Contribution to GDP } & 2.1 & 16.0 & 18.5 & 14.3 & 16.4 & 17.8 \\ \text { Exports of goods and services } & 5.5 & 30.8 & 36.2 & 30.2 & 32.8 & 32.3 \\ \text { Gross fixed investment } & 7.5 & 19.4 & 21.7 & 12.9 & 40.6 & 26.3 \\ \text { Employment, direct } & 0.1 & 0.6 & 0.9 & 1.0 & 0.9 & 0.9\end{array}$

Source: Central Bureau of Statistics, Ministry of Finance

The petroleum sector's contribution to overall GDP expanded rapidly from the early 1970s to the mid-1980s when it reached almost 19 percent of the total (Chart 11). As a result of the collapse in oil prices in 1986, the sector's share in GDP declined in the second half of the 1980s, and despite a very large increase in petroleum sector output in recent years, its share in GDP remains below its peak of the mid-1980s. The same applies to petroleum exports. As a share of total exports of goods and services, petroleum exports rose to more than a third in the mid-1980s, before falling 
CHART 11

NORWAY

\section{PETROLEUM SECTOR}
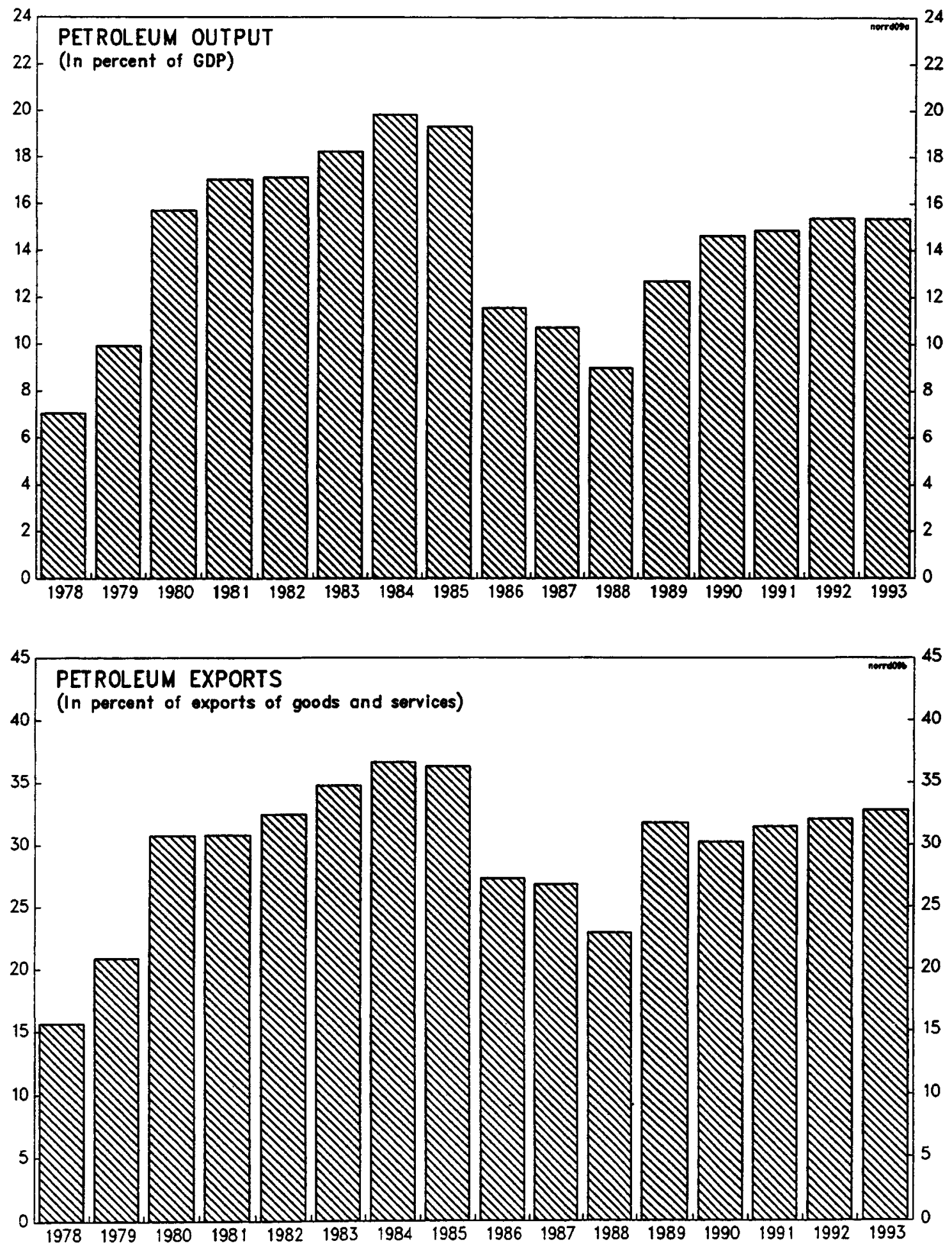

Source: Statistics Norwoy. 
This page intentionally left blank

CInternational Monetary Fund. Not for Redistribution 
to well below 30 percent in the wake of the oil price collapse. More recently, the share of petroleum exports in exports of goods and services has again approached a third. Over the last two decades, petroleum sector investment has accounted for a large, but highly variable, part of gross fixed investment, especially in 1993, when it accounted for more than 40 percent of the total. On the other hand, direct employment in the petroleum sector has always been limited, at most approaching 1 percent of the labor force. However, through links to the mainland economy, particularly to industries that supply investment goods, such as entire oil platforms, to the petroleum production sector, the employment effects have been multiplied to close to 4 percent of the labor force in years of heavy investment in the oil sector.

In the period ahead, petroleum investment is expected to first gradually decline and then fall rapidly as the extraction of discovered resources matures. With some lag, petroleum production is projected to plateau at a level that will be sustained well into the next century. Overall, the petroleum sector's share in output, exports and direct employment can be expected to stabilize at a level somewhat higher than the current one, while the share of investment in gross fixed investment should fall sharply.

\section{Petroleum production and the public sector}

The Norwegian state is heavily involved in the petroleum sector. First, by Norwegian law, the state holds title to all petroleum deposits on the Norwegian continental shelf and issues licenses to firms interested in exploring for or producing oil and gas on the continental shelf. Second, the state is directly engaged in petroleum exploration and production through the wholly state-owned oil company, statoil. Formed in 1972 , Statoll originally accounted for all the state's involvement in 011 and gas production as well as in the transportation, refining and marketing of petroleum and derived products. In 1984, Statoil's participation in most production licenses was divided between Statoil proper and the state Itself. Since then, Statoil's petroleum production activities have been divided into two parts: production for its own account, on the one hand, and the management of the state's direct financial interest in the petroleun sector, on the other. As a result, a part of Statoil's gross revenue from petroleum production is transferred directly to the state and a corresponding part of its expenditure (operating costs, investment, etc.) are paid by the state. The split between the state's direct financial interest, on the one hand, and Statoil, on the other, is determined separately for each production license, but is typically of the order of one-half. The state also takes a direct financial interest in production activities of oil companies other than Statoil, and currently has an interest in most offshore oil and gas fields.

An important objective in Norway's petroleum policy is to secure for the state high and stable revenue from petroleum activities. There are three principal sources of state petroleum revenues. Of these, dividend on 
the state's equity in Statoil is least important. The other two are taxes and royalties paid by oil companies, including Statoil, on the one hand, and the revenues from the state's direct financial interest in the petroleum sector, on the other. The most significant elements of the petroleum tax system are the standard company tax of 28 percent and a special company tax of 50 percent. In addition, a royalty amounting to 8-16 percent of gross production value is levied on oil production from flelds approved for development before 1986. No royalty is levied on gas production.

As the tabulation below shows, central government gross revenue from the petroleum sector has in recent years been relatively stable between 12-15 percent of total revenue.

Central Government Petroleum Revenue 1989-93 (in percent of total revenue)

$\begin{array}{lrrrrr} & 1990 & 1991 & 1992 & 1993 & 1994 \\ \text { Petroleum revenue } & 12.5 & 14.5 & 12.1 & 13.7 & 12.5 \\ \text { Petroleum investment } & 1.2 & 2.0 & 2.6 & 4.9 & 5.0 \\ \text { Net petroleum revenue } & 11.3 & 12.5 & 9.5 & 9.2 & 7.5\end{array}$

Source: Ministry of Finance

However, as a result of a large increase in state investment in the petroleum sector in 1993 and 1994, net petroleum revenue has declined to well below 10 percent of the total. While revenue from the petroleum sector continues to be an important component in overall central government revenue, it is much less so than in the late 1970 s and early 1980 s when more than 20 percent, or even 25 percent in some years, of central government revenue was derived from the petroleum sector. Central government finances, nevertheless, remain vulnerable to fluctuations in the price of oil. Thus, the Ministry of Finance estimates that a 10 percent drop in oil prices could weaken the state budget balance by almost 1 percent of GDP. Furthermore, in the absence of oil revenue fiscal imbalances in Norway would in recent years undoubtedly have turned out far worse than they in fact did.

Looking ahead on the assumption of relatively stable ofl prices, with planned investment in the petroleum sector declining and projected oil and gas production increasing for a few more years, central government net revenue will again increase to close to 15 percent of total revenue.

\section{Petroleum wealth and the permanent income from oil and gas}

Determining the optimal path of extraction of a depletable natural resource, such as petroleum, is a difficult exercise. It involves, inter alia, inter-generational comparisons, and is also fraught with uncertainties, relating for example to estimates of the extent of the petroleum resource and future oil and gas prices and interest rates. This 
exercise will not be attempted here. 1 An alternative approach is to compare the level of petroleum revenue, and the use to which it is put, with the so-called "permanent income" from the petroleum wealth. The permanent income can be defined as the net annual cash flow that could be maintained in perpetuity from an asset equal in value to the present value of net revenue from the petroleum sector summed over its lifespan. It can be argued that in any given year no more than the permanent income from the petroleum resource should be consumed as otherwise net wealth would be eroded.

In their Long-Term Program for 1994-97, the Norwegian authorities provided estimates of the permanent income from the petroleum resource. For the economy as a whole, the permanent income was estimated at around 7 percent of GDP, of which the state's share was put at around threefourths, or 5 percent of GDP. 2/ On occasion in the past, central government net revenue from petroleum has exceeded 5 percent of GDP while its overall balance has also been negative, indicating that public consumption of petroleum revenue has exceeded the permanent income. A corresponding analysis for the economy as a whole--namely comparing the economy's net income from the petroleum sector with the current account balance--indicates that, at least on occasion, the current account surplus has been insufficiently large to prevent overall consumption of oil income from exceeding the countries permanent income from the petroleum wealth.

1. For an example of an exercise in this vein, see Appendix I to $S M / 91 / 37$, which concluded that Norway's consumption of petroleum income verged on being unsustainably large.

2f For a more detailed discussion of these estimates, see Appendix I to SM/93/118. 


\section{The Petroleum Boom and Norway's External Competitiveness I}

\section{Introduction}

A striking development in the Norwegian economy over the past two decades has been the weak performance of the manufacturing sector in the face of the rapid expansion of the petroleum sector. While the petroleum sector's share of total GDP has risen rapidly, output and employment in manufacturing have fallen considerably since the late 1970 s when Norway became a major petroleum producer. For example, from 1981 to 1993, manufacturing output increased by only 8 percent and employment in the sector fell by almost a quarter to under 15 percent of total employment. At the same time, oil and gas output rose threefold and the industry's share in GDP and export of goods and services expanded to 15 percent and 37 percent, respectively. Manufacturing industry's competitiveness, as measured by relative unit labor costs, deteriorated sharply between 1970 and 1988 . Although external competitiveness has improved markedly since 1988, it remains substantially worse than it was before Norway's emergence as a major energy producer.

What accounts for these developments? A stylized result from the socalled Dutch disease literature is that real disturbances, such as a boom in a particular export sector (oll for example), tend to affect competitiveness in the rest of the tradable goods sectors. While these models predict that activity in resource-based sectors will inevitably squeeze out manufacturing production, there have been concerns in Norway that the erosion of external competitiveness induced by the oil and gas discoveries went too far. In addition to the Dutch disease effects, this appendix looks at other contributing factors and concludes that the disappointing perfornance of Norwegian manufacturing and other traditional exports since the 1970s, while reflecting the emergence of the large petroleum sector in the economy, was exacerbated by the economic policies pursued in response to the $0: i$ boom.

Section 2 examines the nature of the "Dutch disease" problems in Norway by relating the oil and gas discoveries to the deterioration of external competitiveness. Evidence of the "Dutch disease" phenomenon is reflected in the real exchange rate appreciation, loss of market shares, increased wage costs, and poor productivity performance in the manufacturing sector in the 1970s and early 1980s. This is followed in section 3 by an exaninactor of the Norwegian policy response to the oil boom and its role in exacerbating the competitiveness problems of the economy. Section 4 provides an account of recent gains in external competitiveness and outlines challenges facing the Norwegian authorities in this regard.

\footnotetext{
1) Prepared by Ousmane C. Dore.
} 


\section{The Dutch disease phenomenon in Norway}

The problems raised by the integration of the oil sector into the Norwegian economy are not uncommon for a newly resource-rich country. As suggested in the literature, some of the effects accompanying a primary export boom may be undesirable. I Generally, an increase in oil production or price will tend to result in a real appreciation of the exchange rate and in a loss of competitiveness of the traditional (non-oil) tradable goods sector (see Annex). The petroleum windfalls will tend to affect the real exchange rate through at least two channels. First, an increase in oil revenue will result in a higher disposable income, and in an increase in the demand for tradable and non-tradable goods. To the extent that the price of other tradables is given by world prices and the exchange rate, this income effect will result in a higher relative price of nontradable goods, and hence in a real appreciation.

Second, an increase in oil revenues will tend, with a fixed exchange rate, to generate a balance of payments surplus and an accumulation of international reserves. If this increase in international reserves is not fully sterilized, the monetary base will expand and inflation will tend to result, leading to real appreciation of the currency; alternatively, if the exchange rate is floating, the real appreciation is likely to come about through a rise in the nominal exchange rate.

Economic developments in Norway since the 1970s have been profoundly influenced by rising petroleum production. 2/ The integration of the oil sector into the Norwegian economy has contributed significantly to improvements in economic welfare. Increased oil and gas revenue generated by rising production and higher international ofl prices facilitated the maintenance of a relatively good overall economic performance by international standards in terms of growth, employment and current account. 3 / However, output in manufacturing and other traditional export industries showed clear signs of stagnation during the early period of petroleum sector expansion (see tabulation below). The rapid expansion of oil and gas production, together with the particular pattern of absorption of petroleum revenue into the domestic economy, all contributed to increasing wage costs and sluggish output growth in manufacturing.

1f The "Dutch Disease" literature contends that an increase in primary or energy-sector exports will squeeze out the traditional export sector and lead to de-industrialization. For a survey, see Corden, W.M. (1984), "Booming sector and Dutch disease economics: survey and consolidation" Oxford Economics Papers.

2/ See Appendix III for an account of the expansion of the petroleum sector in Norway.

3/ For example, overall GDP growth averaged almost 4 percent per year between 1972 and 1983, compared to some $21 / 2$ percent for the OECD average. 
Shares in production and employment (in percent)

\begin{tabular}{|c|c|c|c|c|c|c|c|c|}
\hline & & & out & & & Emp ] & ment & \\
\hline & 1970 & 1980 & 1990 & 1993 & 1970 & 1980 & 1990 & 1993 \\
\hline $\begin{array}{l}\text { anufactur } \\
\text { il and } \mathrm{Ga}\end{array}$ & $\begin{array}{r}21.6 \\
0.7\end{array}$ & $\begin{array}{l}16.0 \\
14.8\end{array}$ & $\begin{array}{l}13.7 \\
13.8\end{array}$ & $\begin{array}{l}13 \\
15\end{array}$ & $\begin{array}{r}23.8 \\
0.6\end{array}$ & $\begin{array}{r}19.8 \\
0.8\end{array}$ & $\begin{array}{r}14.7 \\
1.0\end{array}$ & $\begin{array}{r}14.0 \\
1.0\end{array}$ \\
\hline
\end{tabular}

Source: Central Bureau of Statistics

Indeed, by the late 1980 s, there was a growing recognition that high oil revenue in Norway could be a mixed blessing, because of the Norwegian economy's increasing dependence on oil and its weakening competitive position. The stimulus to domestic spending provided by rising oil revenue, while contributing to a high level of demand that secured full employment, exerted strong pressures on domestic resources. As petroleum revenue was spent in the domestic economy, the increase in domestic demand put upward pressure on wage costs. Consequently, Norway's nominal unit labor costs rose rapidly. After the late 1970s, the deterioration in competitiveness was less pronounced because of periodic devaluations, but the real effective exchange rate nevertheless rose gradually from a trough in 1979 to a peak in 1988, by a total of almost 15 percent. Despite subsequent gains in competitiveness, wage costs for blue-collar workers in 1993 were still 10 percent higher in Norway than in competing countries (see tabulation); this margin has since narrowed further.

Total Wage Costs for Workers in Manufacturing, 1993

$$
\begin{gathered}
\text { Blue-collar } \\
\text { workers }
\end{gathered}
$$

Norway

Trading partners
100

90
Blue - \& whitecollar workers

100

Source: Central Bureau of Statistics.

The marked weakening of the cost competitiveness of the manufacturing industry that started in the 1970 s is reflected in the contraction of traditional export and import-competing industries, as well as in the poor productivity performance of the manufacturing sector. The contraction of traditional exports can be seen in the development of their market shares displayed in Chart 12 , which reveals that domestic traditional industries have lost market shares, with the losses particularly pronounced in the mid1980s. Market losses, measured as the difference between the growth of Norwegian exports of traditional goods and growth of total OECD imports of manufactures, amounted to some 30 percent during the period 1973-86. During the same period, Norwegian industry also lost a significant share of the home market to foreign producers, with market losses particularly large for 
MARKET SHARE OF TRADITIONAL EXPORTS

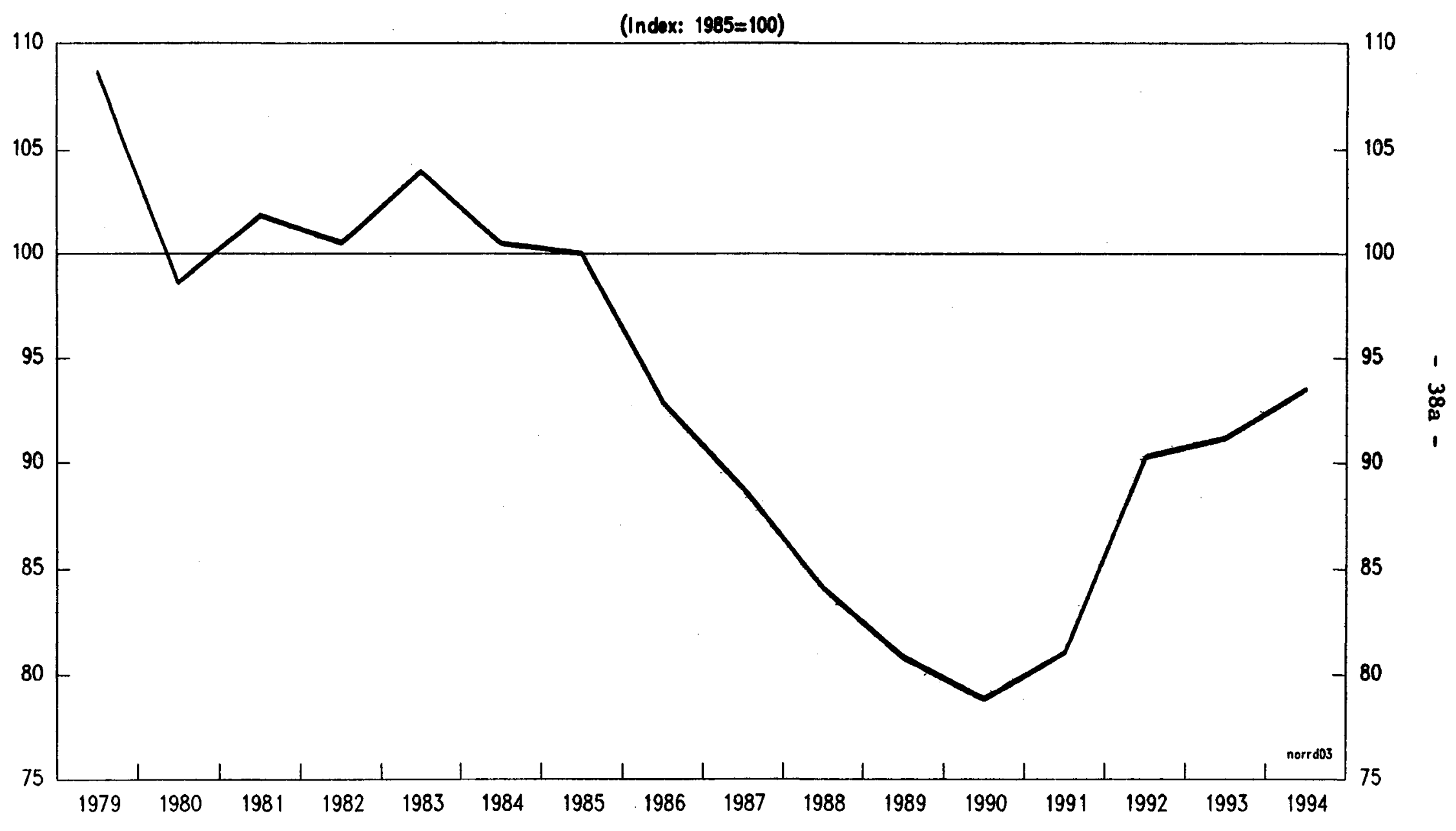

Source: IMF, World Economic Outlook. 
This page intentionally left blank

CInternational Monetary Fund. Not for Redistribution 
pulp and paper products, chemical products and machinery and equipment (see tabulation).

Market Share for Import-Competing Industries (percent of domestic market)

$\begin{array}{lllll} & 1980 & 1986 & 1990 & 1993 \\ & & & & \\ \begin{array}{l}\text { Food \& beverages } \\ \text { Tobacco }\end{array} & 93.6 & 92.3 & 90.9 & 89.2 \\ \begin{array}{l}\text { Textiles \& wearing } \\ \quad \text { apparel }\end{array} & 80.4 & 78.0 & 77.9 & 79.8 \\ \begin{array}{l}\text { Wood products } \\ \text { Chemical \& mineral }\end{array} & 31.5 & 21.9 & 18.7 & 17.5 \\ \text { Mining products } & 81.2 & 72.5 & 75.3 & 71.5 \\ \text { Paper \& pulp } & 50.5 & 42.1 & 39.2 & 35.0 \\ \quad \text { products } & 70.5 & 77.2 & 67.9 & 69.0 \\ \text { Industrial chemicals } & & & & \\ \text { Metals } & 65.2 & 67.3 & 66.7 & 65.5 \\ & 45.1 & 42.9 & 33.1 & 30.6 \\ & 45.4 & 35.7 & 18.6 & 13.3\end{array}$

Food \& beverages

Tobacco

Textiles \& wearing

appare 1

Wood products

Chemical \& mineral

Mining products

Paper \& pulp

products

Industrial chemicals

Metals

\section{(percen}

Source: Central Bureau of Statistics.

\footnotetext{
Source: Central Bureau of statistics.
}

The productivity performance of Norwegian industries was much poorer than in competing countries during the 1970s. Norwegian industry's relative productivity performance deteriorated by 15 percent over the decade to 1977 (see tabulation below). Productivity growth (measured as value-added per man-year) decelerated in all branches with the sharpest slowdown recorded in export competing industries. Although wages on the whole increased somewhat less in Norway than in trading partner countries, their growth was excessive in relation to productivity developments. This led to a faster rise in unit labor costs, a situation which was aggravated by the substantial

appreciation of the effective exchange rate of the krone in the late 1970s.

Relative Unit Labor Costs, 1970-88
$1970-77$
$1978-84$
$1985-88$
1970-88

Contribution to RULC:

$\begin{array}{lrrrr}\text { Relative wages } & 4.0 & -0.2 & 18.1 & 22.0 \\ \text { Relative productivity } & -17.0 & -0.7 & -6.3 & -24.0 \\ \text { RULC, local currency } & 21.0 & 0.5 & 24.4 & 46.0 \\ \text { Exchange rate changes } & -15.4 & 11.0 & 13.5 & 9.0 \\ \text { RULC, common currency } & 36.4 & -10.5 & 10.9 & 37.0\end{array}$

Source: OECD, Central Bureau of Statistics, and Ministry of Finance. 


\section{The Norwegian policy response}

In resource-rich countries, governments are faced with a difficult intertemporal choice of how to use the wealth resulting from natural resources. This issue was thoroughly debated in Norway in the early 1970s. The initial plan was to develop and spend oil revenue cautiously so as to minimize the social and economic costs of structural adjustments. However, while oil and gas production and exports developed much in line with initial expectations, soaring oil prices led to an increase in petroleum wealth and expectations of higher oil revenue. In these circumstances, it proved difficult to resist competing and excessive sectoral claims on resources for various social and regional purposes. Given expectations of rapidly rising petroleum revenue, expansionary policies were followed in order to maintain full employment. Public spending, together with investments related to the offshore activities, were financed by borrowing against future petrcleum revenue.

In conjunction with expansionary demand-management policies, the Norwegian authorities launched an extensive subsidy program towards exposed industries. Support to branches with poor profitability remained high throughout the latter part of the 1970s. The shipbuilding industry, which was one of the hardest hit industries, acquired the lion's share of specific industrial support schemes, together with some of the state-owned enterprises in isolated areas. In addition, a series of state guarantees were given for loans to enterprises in certain branches and regions. I/ By end-1981, the budgetary celling on such guarantees had zeached NKr 106 billion, almost equivalent to expected revenues from oil over the next four years. This generous policy backed by oil wealth enabled the Norwegian economy to achieve full-employment for most of the 1980s, with public sector employment expanding at a rapid rate.

The sharp fall of oil prices in 1986 resulted in a direct loss of real national income of nearly 10 percent while reducing total export earnings by more than 15 percent, underlying the need to reduce domestic demand and shift resources into traditional export and import-competing industries. The size of the required adjustment of output and demand patterns had been increased by strong growth in domestic demand from 1983 to 1986 and the domestic spending of rapidly rising petroleum revenue which were associated with cost and price pressures. The Norwegian authorities responded to this new challenge by reorienting economic policies toward economic stability. In the Revised 1986 National Budget, the Government presented an economic strategy which comprised: (i) a 10 percent devaluation of the krone to restore international competitiveness; (ii) tighter demand-management

1/ Government assistance to businesses took the form of selective direct grants to industries in financial difficulties, tax reliefs, guarantees, equity capital and credit at preferential terms. Moreover, certain sectors, such as agriculture and textiles, received important indirect subsidies, through import protection. 
policies to reduce imports; (iii) a new income policy designed to exert a direct moderating influence on domestic cost and price pressures; and (iv) industrial and structural policies to improve the efficiency of the economy.

The adjustment to lower oil prices continued well into 1988. Domestic demand had been curtailed by austerity policies, but despite the 10 percent devaluation, external competitiveness worsened further in 1986 and 1987 as major structural impediments remained. With no improvement in cost competitiveness and a weak profit position in parts of the exposed sectors, the desired resource transfer from the sheltered sector did not materialize. Manufacturing employment continued to shrink, while the sheltered sectors-especially the public sector--increased employment up to mid-1988. The authorities made some moves in the field of structural reforms and several industrial subsidies were withdrawn. However, the Norwegian business sector remained one of the most heavily subsidized in the OECD, especially in agriculture (see tabulation).

\section{Subsidies to Business Sector (percent of total)}

$\begin{array}{llllll}1980 & 1985 & 1990 & 1991 & 1992 & 1993\end{array}$

$\begin{array}{lrrrrrr}\text { Primary industries } & & & & & \\ \quad \text { Agriculture } & 59.1 & 63.4 & 60.0 & 60.0 & 60.0 & 56.0 \\ \quad \text { Fishing } & 12.8 & 8.3 & 7.0 & 7.0 & 4.0 & 2.5 \\ \text { Manufacturing } & 26.4 & 26.4 & 26.0 & 23.0 & 26.0 & 26.0 \\ \text { Shipbuilding } & 6.9 & 5.1 & 5.0 & 6.0 & 8.0 & 9.1 \\ \text { State companies } & 4.7 & 7.5 & 7.0 & 2.0 & 1.0 & 1.0 \\ \text { Subsidies (percent of GDP) } & & & & & & \\ \quad \text { Norway } & -- & -. & 6.0 & 6.3 & 7.0 & 7.0 \\ \text { OECD average } & -- & -- & 2.1 & 2.1 & 2.1 & 2.1\end{array}$

Source: Ministry of Finance.

\section{Recent developments and challenges ahead}

Since 1988, there have been substantial gains in competitiveness (Chart 13 and tabulation below). Relative unit labor costs in manufacturing declined by close to 10 percent from 1988 to 1991, remained unchanged in 1992, and declined by an additional 5 percent in 1993. This recent recovery in competitiveness is partly due to wage moderation fostered by the deterioration in the employment situation in the late 1980 s and 1990s, but it can also be explained by the exceptionally large gains in labor productivity in recent years, which to some extent reflected labor shedding and the elimination of unproductive capacity. The policy of stable exchange rates pursued since 1986 also contributed to this favorable development. 
Following a strong upswing in the first half of the 1980 s, recession was precipitated by the collapse of oil prices in 1986 and by the bursting of an asset price bubble created by financial deregulation. By 1988, the downturn of the economy had started to show in the labor market. Mainland business employment stagnated. This deterioration in the employment situation in turn fostered wage moderation in the labor market. In addition, in early 1988, a statutory incomes policy was introduced. As a result, average hourly wages increased by only 4.3 percent in 1988 . Due to a 6.4 percent increase in productivity, unit labor costs decreased by 2.1 percent, allowing a significant improvement in relative unit labor costs.

In 1989, moderate wage growth and a large increase in productivity in the course of a general labor "shake out" worked together to limit the growth in unit labor cost to only 0.1 percent, whereas in 1990, relatively large wage increases were only partly offset by continued, albeit slowing, growth in labor productivity. Competitiveness also improved in 1991 and remained broadly unchanged in 1992. The growth in labor costs slowed further in 1993. This, in combination with an estimated effective depreciation of the krone of around 3 percent, led to a 5 percent decline in relative unit labor costs measured in common currency in 1993.

Relative Unit Labor Costs, 1989-94

$\begin{array}{lllllll}1989 & 1990 & 1991 & 1992 & 1993 & 1994 & 1989.94\end{array}$

Contribution to RULC:

Relative wages

Relative productivity

RULC, local currency

Exchange rate changes

$\begin{array}{rrrr}-2.5 & -1.8 & -1.6 & -2.5 \\ 1.5 & -0.1 & -1.1 & -1.6 \\ -4.0 & -1.7 & -0.5 & -0.9 \\ 0.1 & -0.2 & 2.1 & -1.1 \\ -3.7 & -1.4 & -2.5 & 0.3\end{array}$

$-2.1$

$0.0-10.5$

$-0.5 \quad-1.2 \quad-3.0$

$\begin{array}{lll}-1.6 & 1.2 & -7.5\end{array}$

$\begin{array}{lll}3.7 & 1.8 & 6.4\end{array}$

RULC, common currency

$-5.2$

$-13.9$

Source: OECD, Central Bureau of Statistics, and Ministry of Finance.

In its Long-Term Economic Program for 1994-97, issued in early 1993, the Norwegian Government established a 10 percent improvement in competitiveness by 1996 as one of its medium-term goals. While a strengthening of the country's competitive position may be achieved either through domestic cost increases being lower than abroad or an exchange rate cepreciation, or a combination of both, past experience shows that for a smail open econony like Norway, it is extremely difficult to maintain an exchange-rate-induced improvement in competitiveness in conditions of tight iabor markets and a wage formation system characterized by strong wage-price and wage-wage links. Following a currency depreciation, the ensuing improved profit position tends to lead to higher wage growth in the exposed sectors. This will spreac to the rest of the economy, reinforcing the upward pressure or costs anc prices resulting from higher import prices. 


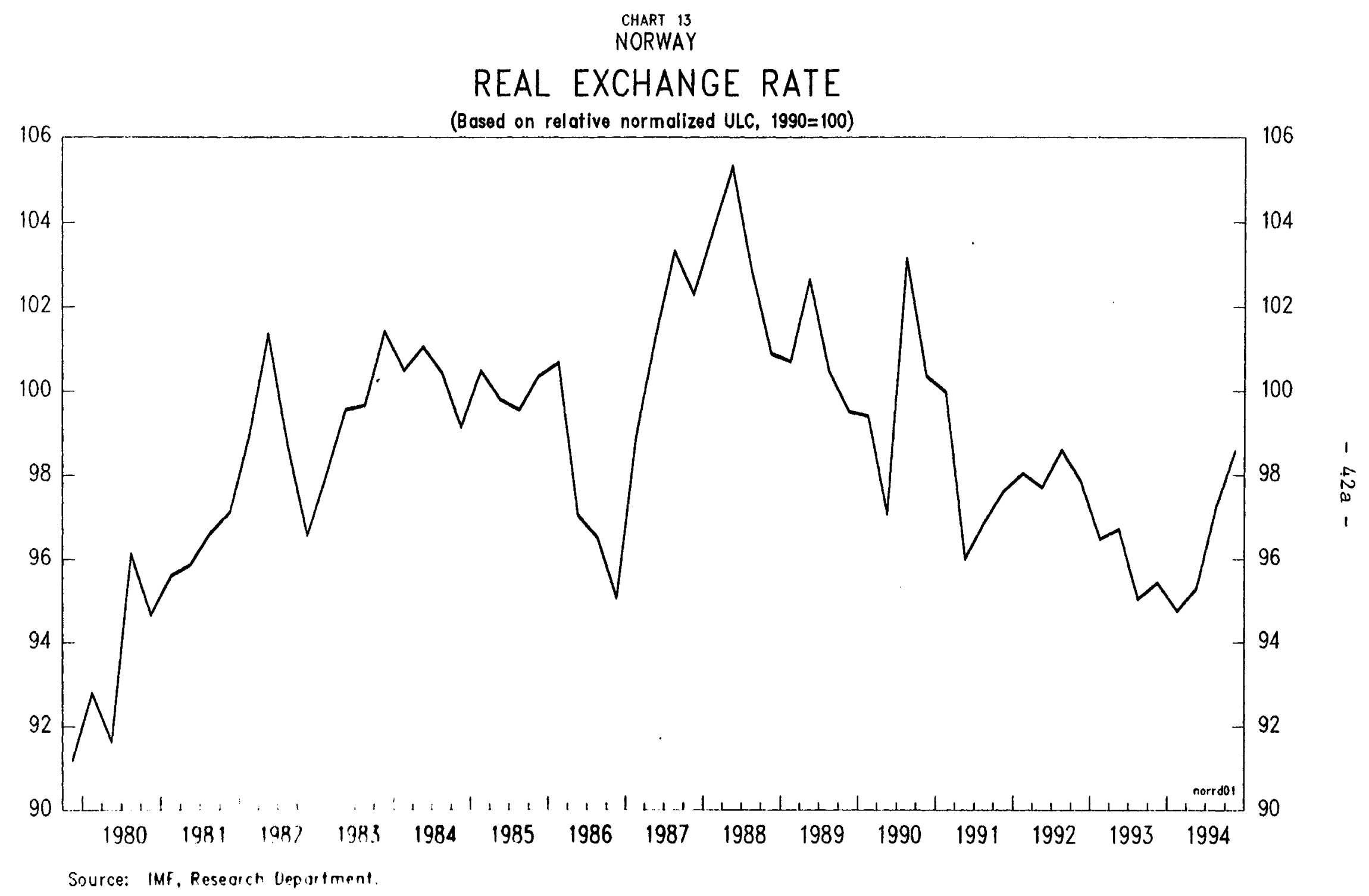

CInternational Monetary Fund. Not for Redistribution 
This page intentionally left blank

CInternational Monetary Fund. Not for Redistribution 
In view of the difficulties in containing the wage-price spiral in the event of a downward adjustment of the exchange rate, the program sought to improve international competitiveness through lower (wage) inflation at home than abroad and improved productivity performance. Substantial progress has been made in recent years toward establishing the conditions for achieving the targeted improvement in competitiveness. Important structural reforms have been introduced to prepare the economy for greater international competition, inflation has for a number of years been lower than among trading partners, interest rates approximate those in partner countries, and wage moderation has been maintained. The challenge remains for the authorities to safeguard these recent gains in external competitiveness at a time when the economy is recovering and inflation differentials vis-a-vis continental Europe have shrunk.

\section{Conclusion}

It has been shown in this appendix that the deterioration of the competitiveness of the Norwegian manufacturing industry that took place in the 1970 s and 1980 s was a case of "Dutch disease" which was aggravated by the economic policies pursued in response to the oll bonanza. While a decline in the share of traditional industries in GDP was unavoidable as a result of the growing energy sector and the domestic use of revenue from oil and gas, the strong growth of public services, transfers and subsidies to ailing industries led to excessive pressures in labor and product markets, which in turn fueled inflation and constrained the expansion of the most competitive enterprises.

The discovery and exploitation of oil and gas in Norway gave rise not only to increased real national income, but also to a redistribution of income between sectors. The income gains were redistributed largely to firms and households through subsidies, transfers and higher public spending. Higher income expectations, notably in the 1970s, were then fed through a centralized system of pay determination to raise wage income in all industries, leading to a more rapid wage increase than warranted by productivity performance, particularly in the traditional export and import competing industries. This situation resulted in a real exchange rate appreciation, which contributed to undermining the competitive position and profitability of those industries.

Wage moderation supported by a fixed exchange rate policy and large gains in labor productivity have contributed significantly to the recent recovery in external competitiveness. Given the authorities' commitment to maintaining stability in the foreign exchange market--as formulated in the new monetary policy guidelines--the targeted improvement in competitiveness will need to come from restraint on labor costs, with appropriate support from fiscal policy. 


\section{Annex}

In this annex, we examine the extent to which an oil boom affects competitiveness in the rest of the tradable goods sectors. Consider a small open economy that produces three goods: ofl ( $(0)$, traditional tradables ( $T$ ) and non-tradables (N). Assume that the oil sector is owned by the government, as is largely the case in Norway, and that the exchange rate is fixed and equal to one.

The excess demand for non-tradables is assumed to depend on prices and income. In equilibrium this excess demand will be equal to zero, 1 .e

$$
\mathbf{N}=\mathbf{N}(\mathbf{r}, \mathbf{y})=0
$$

with $\delta \mathrm{N} / \delta \mathrm{r}>0, \delta \mathrm{N} / \delta \mathrm{y}>0$

Where $r$ the relative price of tradables to non-tradable goods is defined as the real exchange rate, and $y$ is the real income expressed in terms of nontradable goods and given by

$$
\mathrm{y}=\mathrm{H}_{\mathrm{N}}+\mathbf{r} \mathrm{H}_{\mathrm{T}}+\mathrm{R}
$$

where $H_{N}$ and $H_{T}$ are supplies of the non-tradables and tradables respectively, and $R-q 0$ is the ofl revenue in terms of non-tradables. The excess demand for money in nominal terms $(E)$ is given by

$$
E=\mathbf{M}-\mathbf{L}
$$

where $M$ is the nominal supply of money and $L$ is the demand for money in nominal terms. Assuming that the demand for money equation $L$ (in noninal terms) depends on the usual arguments (real income and price), we can write E as

$$
E=E\left(M, P_{N}, P_{T}, Y\right)
$$

By virtue of the homogeneity of degree zero property of the excess demand function, this can be rewritten as

$$
E=E(M, r, y)
$$

with $\delta \mathrm{E} / \delta \mathrm{M}>0, \delta \mathrm{E} / \delta \mathrm{r}>0, \delta \mathrm{E} / \delta \mathrm{y}>0$

We further assume that $E$ is equal to zero only in the long-: ir In particular, an increase of $M$ will result in a short-run excr s supply of money, which will be slowly eliminated through the balance $c$ zyments. It is further assumed that, due to Walras's law, an excess supf $y$ if money will be reflected in as excess demand for non-tradables and an ex 3 . demand for traditional tradables. Then equation (1) has to be modified $: 1$ incorporate 
the assumption that in the short-run, an excess supply of money is partially translated into an excess demand for non-tradables.

$$
N=N(r, y, E)=0
$$

The model is completed by specifying the balance of trade defined as

$$
B=q_{0}-P_{T}\left(T-H_{T}\right)
$$

Our interest is to discover the effect of an increase in oil revenues (R) on the degree of competitiveness of the tradable sector, defined here as the relative price of traditional tradables with respect to non-tradables. Total differentiation of equation (1) upon substitution yields:

$$
\frac{d r}{d R}=\frac{-\left(\frac{\partial N}{\partial y}+\frac{\partial N}{\partial E} \frac{\partial E}{\partial y}\right)}{\frac{\partial N}{\partial r}+H T \frac{\partial N}{\partial y}+\frac{\partial N}{\partial E}\left(\frac{\partial E}{\partial r}+H T \frac{\partial E}{\partial y}\right)}<0
$$

This result indicates that an increase in oll revenues leads to a real appreciation or a deterioration of external competitiveness through two channels, an income effect $(\delta \mathrm{N} / \delta \mathrm{y})$ and a motary effect $(\delta \mathrm{N} / \delta \mathrm{E} \delta \mathrm{E} / \delta \mathrm{y})$. 


\section{The Resolution of the Norwegian Banking Crisis $1 /$}

\section{Introduction and summary}

Following the unprecedented credit expansion of the early 1980s, the Norwegian banking sector experienced successive years of negative operating results and falling asset values. Led by a surge in loan losses, operating results reached a trough in 1991; when post-loss operating profits for commercial and saving banks totalled minus 5.5 percent of their average total assets. By the end of that year, government net financial support to stem the crisis amounted to $\mathrm{NKr}, 18.7$ billion (about 3 percent of GDP) and the country's three largest commercial banks (Den Norske Bank, Christiania Bank, Fokus Bank) had come under majority state ownership. 2 .

As in other Scandinavian countries, the banking crisis in Norway resulted from the interplay of structural and cyclical developments. 3 / Rapid economic growth, financial deregulation and negative post-tax real interest rates led to a sharp fall in the household saving rate as well as to a proliferation of enterprises with rather low and even negative equity capital. 4/ Cyclical factors were reinforced by structural peculiarities of the Norwegian economy--notably, the historically high debt/equity ratio of non-financial enterprises, poor capitalization of the baiking sector and limited supervisory capacity on the part of the Government Bank Insurance and Security Commission. Triggered by the collapse of oil prices in 1986, these factors turned the banks' initial difficulties with the fall in credit demand and poor loan recovery from 1987 into a protracted crisis--the longest among Scandinavian countries.

Although the Norwegian banking crisis was the longest of those in the Scandinavian countries, it also came to the earliest resolution. The first signs of a recovery in balance sheets appeared in early 1992. After a brief reversal in the last quarter of 1992 due to ERM-related turmoil in foreign exchange markets, banks' balance sheets improved considerably in the course of 1993; for the first time sinçe 1986, the commercial banks as a group closed the year with significant post-loss profits without further injection of government funds. Saving banks, which registered positive results already in 1992, also witnessed a sharp increase in operating profits during 1993. This favorable trend in operating results continued in 1994 . As a

1) Prepared by Luis Catão.

2) The three banks together account for 85 percent of the total assets of commercial banks.

3/ For a detailed discussion of the causes of the banking crisis in Norway, see Appendix III of SM/93/118.

4/ The household savings ratio fell from around 5 percent of disposable income in the early 1980 s to minus 6 percent in 1986; the number of enterprises with negative equity capital in retail trade rose from just below 8 percent of the total in 1982 to 14 percent in 1986 . 
result of the substantial recovery in banks' operating results and the rise in the market value of government-owned banking assets, the net direct cost 1/ of government involvement in the banking crisis had fallen, by the end of 1993, to less than 1 percent of GDP, compared with a gross direct cost of 3.2 percent of GDP in 1991 and 1992.

\section{The main determinants of recovery in the banking sector}

After the heavy losses incurred in 1991, banks witnessed a substantial improvement in their balance sheets during the first three quarters of 1992 , as loan loss provisions declined and operating costs continued to be cut. This improvement, however, was partly reversed in the last quarter of 1992 due to the turmoil in money and foreign exchange markets across Europe. Sharp increases in money market interest rates in late 1992 imparted substantial losses to most commercial banks through both a direct effect on profit margins in lending transactions and an indirect effect on asset prices. Further injection of government funds was then necessary to enable the three largest comercial banks to meet international capital adequacy requirements at the end of 1992 .

As interest rates reached a trough in February 1993 and remained low through the first half of 1994, commercial banks experienced a substantial reduction in interest expenditure; meanwhile, asset prices began to pick up due to both the fall in interest rates and rising economic activity. Fostered by these favorable macroeconomic developments, commercial banks as a group ran profits (after credit losses) of $\mathrm{NKr} 2.2$ billion over the year through December 1993 and NKr 2.8 billion in the first half of 1994 , corresponding to 0.6 and 1.5 percent of average total assets, respectively (Table 12). 2/

Saving banks--which represent about 40 to 45 percent of the banking sector--also reaped substantial benefits from recent macroeconomic trends. In comparison with commercial banks, saving banks went further in cutting down costs earlier in the recession and gained more from the lower money market rates due to their higher dependence on borrowing to finance lending operations. As a result, saving banks achieved positive post-loss results already in 1992 and, by December 1993, their post-loss operating profits had risen to 2 percent of average total assets (Table 13). In the first half of

1/ Measured as Government's total expenses on banking support measures minus the market value of government-owned banking assets and revenues from interest and sales of banking shares and warrants. (See Table 14 in Section 3 below.)

2/ Only in 1989 did the banking sector register a post-loss positive operating result for the first time since 1986. Yet, this positive operating result in 1989 was rather small (0.04 percent of total assets) and followed by substantial losses in 1990 and 1991. 
Table 12. Norway: Profit and Loss Accounts of Commercial Banks (In percent of average total assets)

\begin{tabular}{|c|c|c|c|c|c|c|c|}
\hline & \multirow{2}{*}{$\begin{array}{c}1989 \\
\text { Dec. }\end{array}$} & \multirow{2}{*}{$\begin{array}{l}1990 \\
\text { Dec. }\end{array}$} & \multirow{2}{*}{$\begin{array}{c}1991 \\
\text { Dec. }\end{array}$} & \multirow{2}{*}{$\begin{array}{l}1992 \\
\text { Dec. }\end{array}$} & \multicolumn{2}{|c|}{1993} & \multirow{2}{*}{$\begin{array}{l}1994 \\
\text { June }\end{array}$} \\
\hline & & & & & Dec. & June & \\
\hline $\begin{array}{l}\text { Interest and credit } \\
\text { commission income } \\
\text { Interest expenditure }\end{array}$ & $\begin{array}{r}11.75 \\
8.77\end{array}$ & $\begin{array}{r}11.55 \\
9.00\end{array}$ & $\begin{array}{r}10.69 \\
8.24\end{array}$ & $\begin{array}{r}10.44 \\
7.66\end{array}$ & $\begin{array}{l}8.85 \\
5.78\end{array}$ & $\begin{array}{l}9.61 \\
6.58\end{array}$ & $\begin{array}{l}7.43 \\
4.39\end{array}$ \\
\hline Net interest income & 2.98 & 2.55 & 2.45 & 2.78 & 3.07 & 3.03 & 3.04 \\
\hline $\begin{array}{l}\text { Other operating income } \\
\text { Commission income } \\
\text { Gains on securities } \\
\text { Exchange gains } \\
\text { Other operating income }\end{array}$ & $\begin{array}{l}1.35 \\
0.65 \\
0.37 \\
0.25 \\
0.08\end{array}$ & $\begin{array}{l}1.14 \\
0.53 \\
0.08 \\
0.22 \\
0.31\end{array}$ & $\begin{array}{r}0.88 \\
0.53 \\
-0.04 \\
0.26 \\
0.14\end{array}$ & $\begin{array}{r}1.11 \\
0.55 \\
-0.09 \\
0.50 \\
0.15\end{array}$ & $\begin{array}{l}1.51 \\
0.59 \\
0.48 \\
0.26 \\
0.17\end{array}$ & $\begin{array}{l}1.60 \\
0.58 \\
0.57 \\
0.28 \\
0.16\end{array}$ & $\begin{array}{r}0.92 \\
0.61 \\
-0.32 \\
0.46 \\
0.17\end{array}$ \\
\hline $\begin{array}{l}\text { Other operating expenses } \\
\text { Staff costs }\end{array}$ & $\begin{array}{l}2.68 \\
1.24\end{array}$ & $\begin{array}{l}2.91 \\
1.26\end{array}$ & $\begin{array}{l}2.52 \\
1.25\end{array}$ & $\begin{array}{r}-2.32 \\
1.23\end{array}$ & $\begin{array}{l}2.32 \\
1.24\end{array}$ & $\begin{array}{l}2.30 \\
1.17\end{array}$ & $\begin{array}{l}2.37 \\
1.17\end{array}$ \\
\hline $\begin{array}{l}\text { Write-downs and losses } \\
\text { on sales of capital } \\
\text { assets }\end{array}$ & $\cdots$ & $\cdots$ & 0.82 & 0.57 & 0.26 & 0.08 & -0.07 \\
\hline $\begin{array}{l}\text { Pre-loss operating result } \\
\text { Losses on loans and } \\
\text { guarantees } \\
\text { Post-loss operating } \\
\text { result }\end{array}$ & $\begin{array}{l}1.64 \\
1.60 \\
0.04\end{array}$ & $\begin{array}{r}0.79 \\
1.96 \\
-1.17\end{array}$ & $\begin{array}{r}-0.01 \\
4.28 \\
-4.29\end{array}$ & $\begin{array}{r}1.00 \\
2.25 \\
-1.25\end{array}$ & $\begin{array}{l}2.00 \\
1.41 \\
0.58\end{array}$ & $\begin{array}{l}2.26 \\
1.81 \\
0.45\end{array}$ & $\begin{array}{l}1.66 \\
0.14 \\
1.52\end{array}$ \\
\hline $\begin{array}{l}\text { Losses as share of gross } \\
\text { loans }\end{array}$ & 2.11 & 2.62 & 5.89 & 2.84 & 1.82 & 2.35 & 0.18 \\
\hline $\begin{array}{l}\text { Average total assets } \\
\text { (millions of } \mathrm{NKr} \text { ) }\end{array}$ & 374,5184 & 02,561 & 396,770 & 382,255 & 368,3283 & 6,308 & 367,988 \\
\hline
\end{tabular}

Source: Norges Bank. 
Table 13. Profit and Loss Accounts of Saving Banks (Parent Bank). I (Figures expregsed in percent of average total assets)

\begin{tabular}{|c|c|c|c|c|c|c|c|}
\hline & \multirow{2}{*}{$\begin{array}{l}1989 \\
\text { Dec. }\end{array}$} & \multirow{2}{*}{$\begin{array}{l}1990 \\
\text { Dec. }\end{array}$} & \multirow{2}{*}{$\begin{array}{c}1991 \\
\text { Dec. }\end{array}$} & \multirow{2}{*}{$\begin{array}{l}1992 \\
\text { Dec. }\end{array}$} & \multicolumn{2}{|c|}{1993} & \multirow{2}{*}{$\begin{array}{l}1994 \\
\text { June }\end{array}$} \\
\hline & & & & & Dec. & June & \\
\hline $\begin{array}{l}\text { Interest and credit } \\
\text { commission income } \\
\text { Interest expenditure }\end{array}$ & $\begin{array}{r}13.28 \\
9.14\end{array}$ & $\begin{array}{r}12.59 \\
8.74\end{array}$ & $\begin{array}{r}12.04 \\
8.25\end{array}$ & $\begin{array}{r}12.17 \\
7.83\end{array}$ & $\begin{array}{r}10.48 \\
5.75\end{array}$ & $\begin{array}{r}11.49 \\
6.94\end{array}$ & $\begin{array}{l}8.14 \\
3.88\end{array}$ \\
\hline Net interest income & 4.14 & 3.85 & 3.79 & 4.34 & 4.73 & 4.54 & 4.26 \\
\hline $\begin{array}{l}\text { Other operating incone } \\
\text { Commission income } \\
\text { Gains on securities } \\
\text { Exchange gains } \\
\text { Other operating incone }\end{array}$ & $\begin{array}{l}1.06 \\
0.52 \\
0.38 \\
0.08 \\
0.08\end{array}$ & $\begin{array}{l}0.71 \\
0.47 \\
0.01 \\
0.09 \\
0.14\end{array}$ & $\begin{array}{r}0.63 \\
0.49 \\
-0.07 \\
0.11 \\
0.10\end{array}$ & $\begin{array}{r}0.82 \\
0.59 \\
-0.04 \\
0.17 \\
-0.10\end{array}$ & $\begin{array}{l}1.52 \\
0.63 \\
0.68 \\
0.10 \\
0.09\end{array}$ & $\begin{array}{l}1.54 \\
0.59 \\
0.74 \\
0.11 \\
0.09\end{array}$ & $\begin{array}{r}0.13 \\
0.65 \\
-0.64 \\
0.04 \\
0.08\end{array}$ \\
\hline $\begin{array}{l}\text { Other operating expenses } \\
\text { Staff costs }\end{array}$ & $=5 \begin{array}{l}3.26 \\
1.46\end{array}$ & $\begin{array}{l}3.28 \\
1.48\end{array}$ & $\begin{array}{l}3.32 \\
1.54\end{array}$ & $\begin{array}{l}3.17 \\
1.55\end{array}$ & $\begin{array}{l}3.03 \\
1.39\end{array}$ & $\begin{array}{l}2.98 \\
1.39\end{array}$ & $\begin{array}{l}2.97 \\
1.40\end{array}$ \\
\hline $\begin{array}{l}\text { Write-downs and losses } \\
\text { on sales of capital } \\
\text { assets }\end{array}$ & $\cdots$ & $\cdots$ & 0.20 & 0.12 & $\cdots$ & -0.01 & -0.02 \\
\hline $\begin{array}{l}\text { Pre-loss operating } \\
\text { result } \\
\text { Losses on loans and } \\
\text { guarantees } \\
\text { Post-loss operating } \\
\text { result }\end{array}$ & $\begin{array}{r}1.94 \\
2.24 \\
-0.30\end{array}$ & $\begin{array}{r}1.28 \\
2.05 \\
-0.77\end{array}$ & $\begin{array}{r}0.90 \\
2.11 \\
-1.21\end{array}$ & $\begin{array}{l}1.87 \\
1.83 \\
0.04\end{array}$ & $\begin{array}{l}3.21 \\
1.19 \\
2.03\end{array}$ & $\begin{array}{l}3.12 \\
1.31 \\
1.81\end{array}$ & $\begin{array}{l}1.44 \\
0.46 \\
0.98\end{array}$ \\
\hline $\begin{array}{l}\text { Losses as a share of } \\
\text { gross loans }\end{array}$ & 2.87 & 2.58 & 2.57 & 2.08 & 1.36 & 1.36 & 0.54 \\
\hline $\begin{array}{l}\text { Average total assets } \\
\text { (millions of } \mathrm{NKr} \text { ) }\end{array}$ & 200,290 & 203,719 & 197,841 & 185,449 & 193,526 & 201.766 & 207.920 \\
\hline
\end{tabular}

Source: Norges Bank.

1) For the years 1989-1993 the table includes the 24 largest saving banks (about 78 percent of total assets). 
1994, however, the saving banks' performance weakened somewhat. Two factors account for this. On the one hand, competition for market shares led some saving banks to pass some of the gains of lower money market rates on to customers, thereby leading to a sharper fall in interest and credit commission income of the saving banks as a group. On the other hand, due to their more favorable initial position, saving banks had a much smaller number of non-performing loans to recover than commercial banks. As a result, saving bariks could not benefit as much from continuing macroeconomic recovery in 1994, though their balance sheets remain, on average, far healthier today than at any time during 1987-91.

In addition to the favorable macroeconomic conditions, a number of cost-saving measures contributed to: the stronger performance of the Norwegian banking sector. Between 1988 and 1992 comercial banks reduced staff by about 30 percent (5,000 people) and closed 40 percent of their branches ( 300 branches). An outcome of such a sharp contraction was that the number of employees and office branches by 1992 were both somewhat lower than in 1981, notwithstanding the fact that banking deposits and loans increased in real terms by 250 and 300 percent, respectively, over the same period. 1 Similar trends in cost reduction and rationalization were also observed for saving banks. Although their number of employees rose slightly between 1981 and 1992, the reduction of branches was substantial--from 1,796 in 1981 to 1,661 in 1992. The decline in operating expenses resulting from these cost-reduction measures partially offset the fall in net interest revenues before 1992. Further cost-cutting measures and the continuing fall in operating costs also contributed to the positive operating results observed for 1993 and the first half of 1994.

An important indicator of the role of cost reduction measures in strengthening banks' balance sheets is the capital adequacy ratio. During 1986-87, the capital adequacy ratio of commercial banks averaged

7.4 percent, while that of saving banks averaged 5.0 percent. In the trough of the crisis (before government intervention), this ratio fell to less than 4 percent in some large banks (e.g. the Christiania Bank)--i.e., well below the 8.0 percent requirement recommended by the Bank of International Settlement (BIS). Under the more.stringent prudential rules enforced in 1991, and as a result of downsizing and government injection of new equity capital, the capital adequacy ratio of commercial banks rose to over 10 percent in 1992, while that of saving' banks increased even further (to 12 percent). Since then both commercial and saving banks have displayed average capital ratios well above 8 percent.

\section{The role of government support and the cost of the banking crisis}

The nature of government intervention in the banking crisis in Norway differed from that adopted in other Nordic countries--notably, Sweden. In

1 Computed as the value of total deposits and loans from the banking system to the private sector and municipalities deflated by the CPI. 
Sweden, govermment support to ailing banks took a wide variety of forms, which included the provision of loan guarantees, loans at concessional rates, the purchase of outstanding shares for an initially unspecified price, and parliamentary approval for the Government to honor all banks' liabilities with no limit being set on the amount that could be spent. In addition, the Swedish Government restructured the sector according to the "bad bank" approach, which effectively led to the splitting of some large banks (e:g. the Nordbanken, the Gota Bank) into a "good" and a "bad" bank-. where the latter took on all "bad," or non-performing, loans of the parent bank. I/

In Norway, all assets and liablifties were kept within the same ailing banks and government support was largely centered on channeling resources through specific guarantee funds, based on pre-defined budget allocations. Before 1991, the two institutions in charge of providing emergency assistance to banks in difficulties were the Comercial Banks Guarantee Fund (CBGF) and the Saving Banks Guarantee Fund (SBGF), both built up with banks' own contributions. In the early part of the crisis, they played the important role of channelling funds to facilitate mergers between ailing banks and stronger ones, which helped to avoid widespread bankruptcy. 2/ With the surge of heavy losses among large banks in 1990-91, however, it became clear that the two funds alone would be insufficient to meet the sector's capital needs. To this end, the Government Bank Insurance Fund (GBINSF) was created in March 1991. With an initial capitalization of NKr 5 billion, the GBINSF aimed at increasing banks' equity capital as well as complementing the assistance from the commercial and saving banks' insurance funds.

As loss provisions rose sharply towards the end of 1991 , additional support measures proved to be necessary to recapitalize some large banks and shore up confidence in the banking system. These included a NKr 6 billion increase in the GBINSF capital as well as a budgetary allocation of NKr 1 billion to the Saving Banks Guarantee Fund. Moreover, in 1ight of banks' difficulties in raising new equity capital from private sources, the Government set up a new fund--the Government Bank Investment Fund (GBINVF) --

1/ For a discussion of the advantages and disadvantages of the "bad bank" approach in general and in the Swedish context in particular, see Report by the Commission on the Banking Crisis, Government Administration Services, Oslo, 1992.

2f During the whole 1987-91 period, only one bank, Norion Bank, was liquidated and had its loans assumed by public administration. 
with an initial capital of MKr 4.5 billion. 1/ Finally, banks could also count on support fron the Norges Bank through subsidized deposits for a 6 -month duration. The implicit subsidy associated with these deposits amounted to MKr 2 billion.

By December 1993, gross goverment expenditures related to the banking crisis--channelled either through the Central Bank, the Treasury, or the Government Inourance and Investment Punds--anounted to Mkr 19.2 billion to commercial banks and NRr 4.5 billion to saving banks (Table 14), for a total of NRr 23.7 billion, or 3.2 percent of GDP. This is a relatively small figure compared with those for Finland and Sweden. 2/ In net terms, the direct cost of goverment support to the banking industry has been even lower. Due to the substantial improvement in the banks' operating performance and rising asset values, the goverment stake in the comerclal banking sector Increased to NKr 15.4 billion by December 1993, while government-owned assets in the saving banks rose to NKr 1.7 billion, for a total of NKr 17.1 billion. This implies that the net direct cost of government intervention in support of the banking system amounted NKr 6.4 million (0.9 percent of GDP) by the end of 1993.

1 In contrast with most of the grants channelled through the CBIF. government expenditures associated with the Investment Fund were of a different nature; as the recovery of the banking sector gathered monentum, such expenditures were expected to yield profits for the budget. Accordingly, expenditures with the Government Bank Investment Fund were recorded as equity investnent in the fiscal budget, rather than another expenditure item in the Government's current account.

2/ By the end of 1993, the Swedish banking system required government support totalling SKr 90 billion or 6 percent of GDP. In Finland, government support amounted to just over Fmk 40.5 billion, or 8 percent of GDP. 
Table 14. Government Expenses in Connection with the Banking Crisis at December 31, 1993

(NKr billions)

\begin{tabular}{lccc}
\hline & $\begin{array}{c}\text { Commercial } \\
\text { Banks }\end{array}$ & $\begin{array}{c}\text { Saving } \\
\text { Banks }\end{array}$ & $\begin{array}{c}\text { Commercial } \\
\text { Banks and } \\
\text { Saving Bank }\end{array}$ \\
\hline $\begin{array}{l}\text { Disbursements including } \\
\text { interest expenses 1/ }\end{array}$ & 19.2 & 4.5 & 23.7 \\
$\begin{array}{l}\text { Revenues 2/ farket value of assets } \\
\text { Net government expenses (NGE) }\end{array}$ & 0.1 & 0.1 & 0.2 \\
(NGE as percent of GDP) & 15.4 & 1.7 & 17.1 \\
& $\frac{3.7}{6.5}$ & $\frac{2.7}{6.4}$ & 0.9 \\
\hline
\end{tabular}

Source: Norges Bank.

1/ Interest expenses in connection with the disbursements are discounted on the basis of the interest rate on government bonds of 5-year residual maturity.

2) Includes interest payments on subordinate loan capital and services from sale of shares and warrants. The values are discounted on the basis of the interest rate on government bonds with a 5-year residual maturity. 
Table A1. Norway: Demand and Supply

\begin{tabular}{|c|c|c|c|c|c|c|c|}
\hline & 1992 & 1988 & 1989 & 1990 & 1991 & 1992 & 1993 \\
\hline & \multirow{2}{*}{$\begin{array}{l}\text { In billions } \\
\text { of } \mathrm{NKK}\end{array}$} & & & & & & \\
\hline & & \multicolumn{6}{|c|}{ (Volume changes in percent) } \\
\hline Private consumption & 365.2 & -2.8 & -2.8 & 2.8 & -0.0 & 1.8 & 1.7 \\
\hline Public consumption & 157.2 & 0.5 & 2.6 & 2.1 & 2.6 & 4.4 & 1.8 \\
\hline Gross fixed investment & 135.2 & 1.6 & -3.9 & -26.8 & 1.7 & 4.5 & 3.0 \\
\hline Stock changes $1 /$ & -5.8 & -2.8 & -2.4 & 3.1 & -2.0 & -1.7 & 5.0 \\
\hline Oil platforms under construction & 3.4 & -0.5 & -1.1 & 4.1 & -0.9 & -1.1 & -2.3 \\
\hline Other & -9.2 & -0.1 & 0.0 & 0.1 & -0.0 & -0.0 & 0.0 \\
\hline Total domestic demand & $\underline{651.8}$ & -4.0 & -4.8 & $\underline{-2.2}$ & $\underline{-1.5}$ & $\underline{0.9}$ & 3.2 \\
\hline Exports of goods and services & 303.2 & 5.5 & 10.7 & 8.1 & 6.1 & 6.2 & 1.8 \\
\hline Oil and gas & 97.2 & 11.5 & 24.7 & 1.8 & 17.0 & 10.8 & 5.8 \\
\hline Other & 206.0 & 3.4 & 6.5 & 10.6 & 1.4 & 4.1 & -0.1 \\
\hline Imports of goods and services & 252.0 & -1.7 & 0.9 & 2.2 & 1.7 & 2.8 & 3.3 \\
\hline Gross domestic product & $\underline{703.0}$ & -0.5 & $\underline{0.6}$ & 1.7 & 1.6 & 3.4 & $\underline{2.3}$ \\
\hline Mainland GDP $\underline{2}$ & $\underline{584.8}$ & -1.7 & -2.2 & 1.1 & -0.6 & $\underline{2.1}$ & $\underline{2.0}$ \\
\hline
\end{tabular}

Source: Okonomiske analyser, various issues.

1/ Changes in percent of previous year's GDP.

2/ Excludes items related to petroleum exploitation and ocean shipping. 
Table A2. Norway: Private Consumption

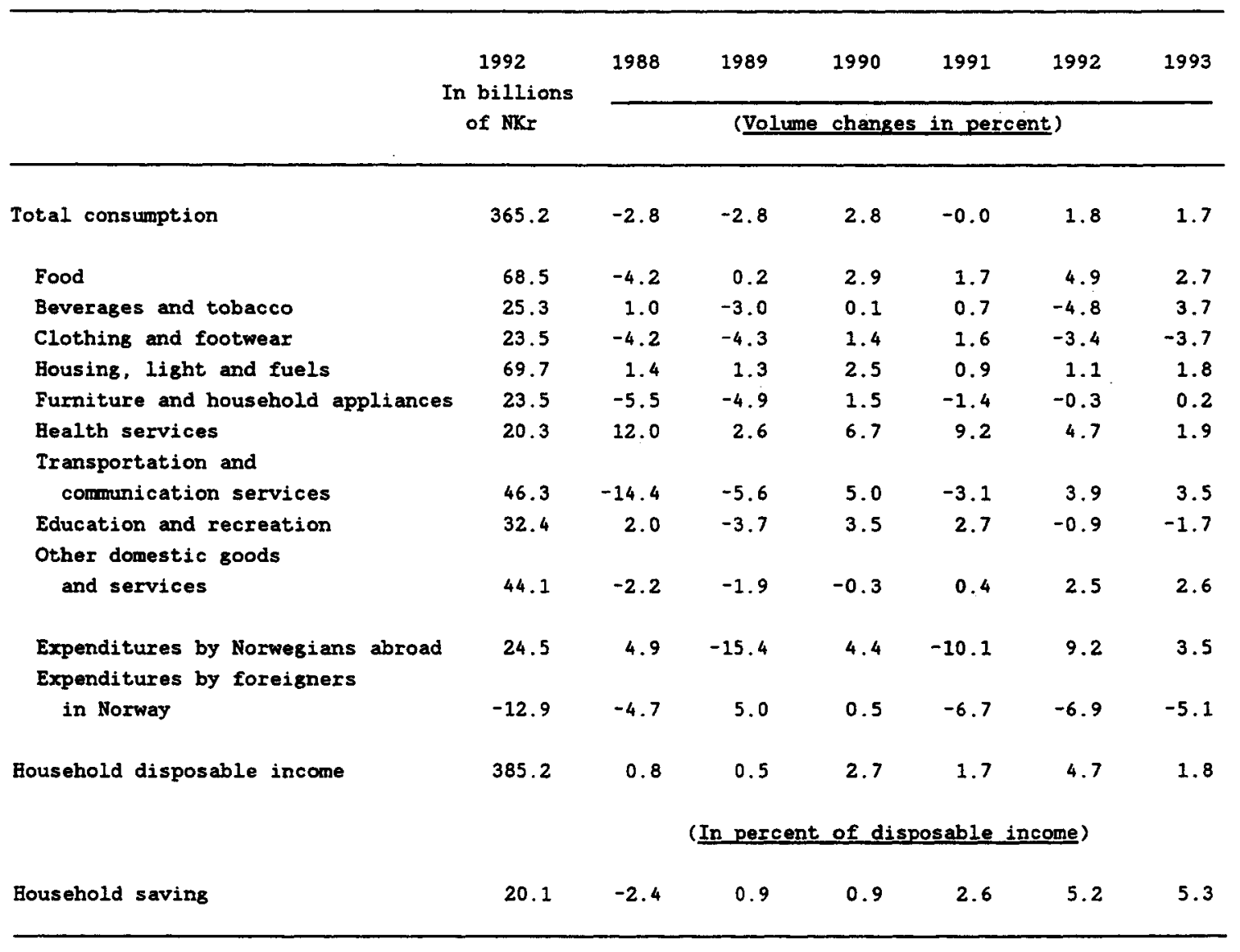

Source: Okonomiske analyser, various issues. 
Table A3. Norway: Household Income and Saving

\begin{tabular}{|c|c|c|c|c|c|c|c|}
\hline & 1991 & 1988 & 1989 & 1990 & 1991 & 1992 & 1993 \\
\hline & \multirow{2}{*}{$\begin{array}{l}\text { In billions } \\
\text { of } \mathrm{NKr}\end{array}$} & & & & & & \\
\hline & & \multicolumn{6}{|c|}{ (Volume changes in percent) } \\
\hline Gross income & 605.6 & 12.1 & -23.6 & 15.4 & 20.4 & 21.6 & 5.2 \\
\hline Wages & 303.6 & -0.9 & -2.5 & -0.7 & 0.2 & 0.7 & 1.1 \\
\hline \multicolumn{8}{|l|}{ Employers social security } \\
\hline contributions & 52.7 & 3.2 & -4.2 & -0.7 & -0.3 & 1.6 & -10.6 \\
\hline Profits & 59.5 & 2.6 & -2.9 & 7.0 & -2.2 & 1.6 & 5.8 \\
\hline Interest earnings & 41.5 & 14.0 & -7.7 & -1.4 & -4.7 & 3.1 & -22.3 \\
\hline Income transfers from government & 140.9 & 7.8 & 7.5 & 4.1 & 4.9 & 4.3 & 2.1 \\
\hline Income transfers from abroad & 2.3 & 11.1 & -1.7 & 6.0 & 9.7 & 12.0 & 28.7 \\
\hline Other income & 5.0 & -25.7 & -12.0 & 1.0 & 2.8 & -1.6 & 0.4 \\
\hline Expenses & 246.4 & 4.3 & -3.6 & -1.2 & -0.8 & -2.2 & -4.6 \\
\hline \multicolumn{8}{|l|}{ Direct taxes and social } \\
\hline security contributions & 174.6 & 2.5 & -3.8 & -0.6 & 0.0 & -0.9 & -0.6 \\
\hline Interest payments & 62.6 & 12.6 & -3.9 & -2.7 & -5.1 & -7.9 & -17.3 \\
\hline Other expenses & 9.3 & 1.1 & 3.1 & -1.8 & 17.9 & 12.2 & -0.9 \\
\hline Household disposable income & 358.9 & 0.8 & 0.5 & 2.7 & 1.7 & 4.7 & 1.8 \\
\hline Private consumption & 349.7 & -2.8 & -2.8 & 2.8 & -0.0 & 1.8 & 1.7 \\
\hline Saving $\underline{1} /$ & 9.2 & $\cdots$ & $\cdots$ & $\cdots$ & $\cdots$ & $\cdots$ & $\cdots$ \\
\hline Net fixed investment 1 & -2.1 & $\ldots$ & $\ldots$ & $\ldots$ & $\ldots$ & $\cdots$ & . . \\
\hline \multirow[t]{2}{*}{ Net financial investment $1 /$} & 11.2 & $\cdots$ & $\cdots$ & $\cdots$ & $\cdots$ & $\cdots$ & $\cdots$ \\
\hline & \multicolumn{7}{|c|}{ (In percent of disposable income) } \\
\hline Saving rate & $\cdots$ & -2.4 & 0.9 & 0.9 & 2.6 & 5.2 & 5.3 \\
\hline Net fixed investment & $\ldots$ & 5.0 & 2.4 & 0.7 & -0.6 & $\ldots$ & $\ldots$ \\
\hline Net financial investment & $\ldots$ & -7.4 & -1.5 & 0.2 & 3.1 & $\ldots$ & .. \\
\hline
\end{tabular}

Source: Okonomiske analyser, various issues.

1/ Saving is negative in some years and the changes are therefore not shown. 
Table A4. Norway: Gross Fixed Investment

\begin{tabular}{|c|c|c|c|c|c|c|c|}
\hline & 1992 & 1988 & 1989 & 1990 & 1991 & 1992 & 1993 \\
\hline & \multirow{2}{*}{$\begin{array}{l}\text { In billions } \\
\text { of } \mathrm{NKK}\end{array}$} & & & & & & \\
\hline & & \multicolumn{6}{|c|}{ (Volume changes in percent) } \\
\hline Total investment & 135.2 & 1.6 & -3.9 & -26.8 & 1.7 & 4.5 & 3.0 \\
\hline Private investment & 109.6 & 0.7 & -4.6 & -29.9 & -1.0 & 4.3 & 43.8 \\
\hline Housing & 12.3 & -3.8 & -17.0 & -17.1 & -27.3 & -12.6 & -5.2 \\
\hline \multicolumn{8}{|l|}{ Agriculture, forestry } \\
\hline and fishing & 4.8 & -1.8 & -23.1 & -20.1 & -8.0 & -3.1 & 2.6 \\
\hline Petroleum exploitation & 41.7 & -4.2 & 25.0 & -62.7 & 88.4 & 31.3 & 50.3 \\
\hline Manufacturing and mining & 13.5 & -12.9 & -26.3 & 6.3 & -7.8 & -0.4 & -1.2 \\
\hline Electricity generation & 6.0 & -3.2 & -21.9 & -16.8 & -5.0 & 4.8 & -5.0 \\
\hline Construction & 1.5 & 2.3 & -33.3 & -7.8 & -30.3 & 5.2 & -4.0 \\
\hline Trade and commerce & 5.8 & -31.8 & -22.0 & 20.1 & 8.8 & 11.8 & 7.7 \\
\hline Ocean shipping and oil drilling $1 /$ & 1.4 & $\cdots$ & $\ldots$ & $\cdots$ & $\ldots$ & $\cdots$ & $\ldots$ \\
\hline Transportation & 12.4 & -19.5 & 0.9 & -1.6 & 12.5 & 17.2 & -8.0 \\
\hline Financial services & 3.1 & 10.5 & -36.6 & 24.6 & -26.1 & 1.4 & -5.8 \\
\hline Other & 7.1 & -9.7 & -19.1 & -23.7 & -13.3 & -2.6 & 6.4 \\
\hline Public investment & 25.6 & 7.4 & 0.7 & -7.1 & 14.4 & 5.3 & -11.6 \\
\hline Central government & 12.6 & 13.6 & 16.6 & -1.0 & 22.5 & 10.4 & -18.5 \\
\hline Local government & 13.0 & 4.4 & -7.9 & -11.3 & 8.1 & 0.8 & -5.0 \\
\hline \multicolumn{8}{|l|}{ Memorandum item: } \\
\hline Mainland investment $\underline{2} /$ & 92.1 & -6.2 & -16.5 & -8.3 & -5.8 & 2.1 & -4.7 \\
\hline
\end{tabular}

Source: Okonomiske analyser, various issues.

1/ Investment in ocean shipping and oil drilling negative in some years and therefore not shown.

2f Excludes items related to petroleum exploitation and ocean shipping 
Table A5. Norway: Real GDP by Sector

\begin{tabular}{|c|c|c|c|c|c|c|c|}
\hline & 1991 & 1988 & 1989 & 1990 & 1991 & 1992 & 1993 \\
\hline & \multirow{2}{*}{$\begin{array}{l}\text { In billions } \\
\text { of } \mathrm{NKr}\end{array}$} & & & & & & \\
\hline & & \multicolumn{6}{|c|}{ (Volume changes in percent) } \\
\hline Total economy & 686.7 & -0.5 & 0.6 & 1.7 & 1.6 & 3.4 & 2.3 \\
\hline Business sector & 533.3 & 0.8 & 1.9 & 1.3 & 1.3 & 3.1 & 2.1 \\
\hline \multicolumn{8}{|l|}{ Agriculture, forestry } \\
\hline and fishing & 20.1 & 1.1 & 2.9 & 11.5 & 0.9 & -0.9 & 8. 1 \\
\hline Petroleum exploitation & 99.7 & 9.9 & 25.4 & 2.6 & 13.9 & 12.3 & 5.7 \\
\hline Manufacturing and mining & 94.3 & -4.8 & -1.1 & 0.5 & -2.1 & ... & $\ldots$ \\
\hline Electricity generation & 26.4 & 6.4 & 10.1 & 0.4 & -9.8 & 6.0 & 2.0 \\
\hline Construction & 24.7 & -1.0 & -8.0 & -4.0 & -5.5 & -0.0 & -3.1 \\
\hline Trade and commerce & 66.7 & -5.4 & -2.1 & 0.5 & -1.1 & 1.2 & 1.6 \\
\hline Ocean shipping and oil drilling & 23.2 & -4.0 & 19.2 & 16.2 & 3.8 & -3.6 & -6.9 \\
\hline Transportation & 40.7 & 6.9 & 0.1 & 6.1 & 4.5 & -0.7 & 1.5 \\
\hline Housing & 33.8 & 6.0 & 5.5 & 2.9 & -1.2 & 0.5 & 0.3 \\
\hline Financial services & 27.9 & 3.0 & -7.4 & -4.0 & -6.3 & -2.1 & 0.4 \\
\hline Other & 75.9 & -1.0 & -5.1 & -2.7 & 0.1 & 2.3 & 2.1 \\
\hline Public sector & 111.9 & 2.2 & 1.8 & 2.6 & 3.2 & 3.6 & 2.8 \\
\hline Central government & 33.2 & 0.6 & 1.5 & 3.2 & 1.1 & 2.8 & 1.3 \\
\hline Local government & 78.7 & 2.9 & 1.9 & 2.3 & 4.2 & 3.9 & 3.4 \\
\hline \multicolumn{8}{|l|}{ Memorandum item: } \\
\hline Mainland economy $1 /$ & 563.8 & -1.7 & -2.2 & 1.1 & -0.6 & 2.1 & 2.0 \\
\hline
\end{tabular}

Source: Okonomiske analyser, various issues.

1/ Excludes items related to petroleum exploitation and ocean shipping. 
Table A6. Norway: Indicators of Petroleum Activities

\begin{tabular}{|c|c|c|c|c|c|c|}
\hline & 1988 & 1989 & 1990 & 1991 & 1992 & 1993 \\
\hline & \multicolumn{6}{|c|}{ (In billions of kroner) } \\
\hline Export value & 48.8 & 73.5 & 88.5 & 96.7 & 97.2 & 104.1 \\
\hline Accrued taxes and royalties & 10.7 & 17.1 & 28.1 & 28.6 & 27.8 & .. \\
\hline Paid taxes and royalties & 11.9 & 13.9 & 26.1 & 32.1 & 24.7 & .. \\
\hline \multirow[t]{2}{*}{ Net cash flow } & 2.7 & 14.7 & 34.2 & 39.5 & 28.6 & ... \\
\hline & \multicolumn{6}{|c|}{ (In millions of ton oil equivalent) } \\
\hline Production of crude oil and gas & 86 & 105 & 109 & 122 & 136 & 143 \\
\hline Crude oil & 56 & 74 & 82 & 94 & 107 & 114 \\
\hline \multirow[t]{2}{*}{ Natural gas } & 30 & 31 & 28 & 27 & 29 & 29 \\
\hline & \multicolumn{6}{|c|}{ (In percent) } \\
\hline \multicolumn{7}{|l|}{ Petroleun exports as a } \\
\hline share of total exports & 22.9 & 31.7 & 30.2 & 31.4 & 32.0 & 32.8 \\
\hline \multicolumn{7}{|l|}{ Petroleum exports as a } \\
\hline \multirow[t]{2}{*}{ share of total GDP } & 8.4 & 11.8 & 13.4 & 14.1 & 13.8 & 14.2 \\
\hline & \multicolumn{6}{|c|}{ (In kroner per barrel) } \\
\hline Price of Norwegian crude oil & 96 & 124 & 148 & 133 & 120 & 121 \\
\hline \multicolumn{7}{|l|}{ Memorandum item: } \\
\hline \multicolumn{7}{|l|}{ Price of Norwegian crude oil } \\
\hline (in US dollars per barrel) & 14.7 & 18.0 & 23.6 & 20.5 & 19.3 & 17.1 \\
\hline
\end{tabular}

Source: Okonomiske Analyser; Olje- Og gassvirksombet; and Nasjonalbudsjettet. 
Table A7. Norway: Indicators of International

Competitiveness and Trade Performance

(Annual percentage change)

\begin{tabular}{|c|c|c|c|c|c|c|}
\hline & 1988 & 1989 & 1990 & 1991 & 1992 & 1993 \\
\hline \multicolumn{7}{|l|}{ Terms of trade } \\
\hline All goods & -3.6 & 3.7 & 2.2 & -1.2 & -7.8 & 0.6 \\
\hline Traditional goods & 6.4 & 1.7 & -4.3 & 0.1 & -4.9 & -0.2 \\
\hline Nominal effective exchange rate & -0.1 & 0.1 & -0.7 & -1.6 & 1.1 & -1.4 \\
\hline Relative unit labor costs & 5.7 & -4.4 & -1.9 & -2.5 & 0.1 & -2.0 \\
\hline \multicolumn{7}{|l|}{ Exports of traditional goods } \\
\hline In real terms & 9.0 & 5.4 & 9.9 & -2.7 & 4.1 & 3.0 \\
\hline Export markets & 8.6 & 7.1 & 4.5 & 1.3 & 3.4 & 0.7 \\
\hline Export market share & -5.3 & -3.9 & -2.5 & 2.8 & 11.4 & 1.0 \\
\hline \multicolumn{7}{|l|}{ Imports of traditional goods } \\
\hline $\begin{array}{l}\text { In real terms } \\
\text { Mainland domestic demand }\end{array}$ & -7.2 & -4.8 & 9.8 & 0.2 & 3.9 & 1.8 \\
\hline
\end{tabular}

Source: Central Bureau of Statistics, National Accounts Statistics; and IMF Research Department. 
Table A8. Norway: Exports of Goods and Services

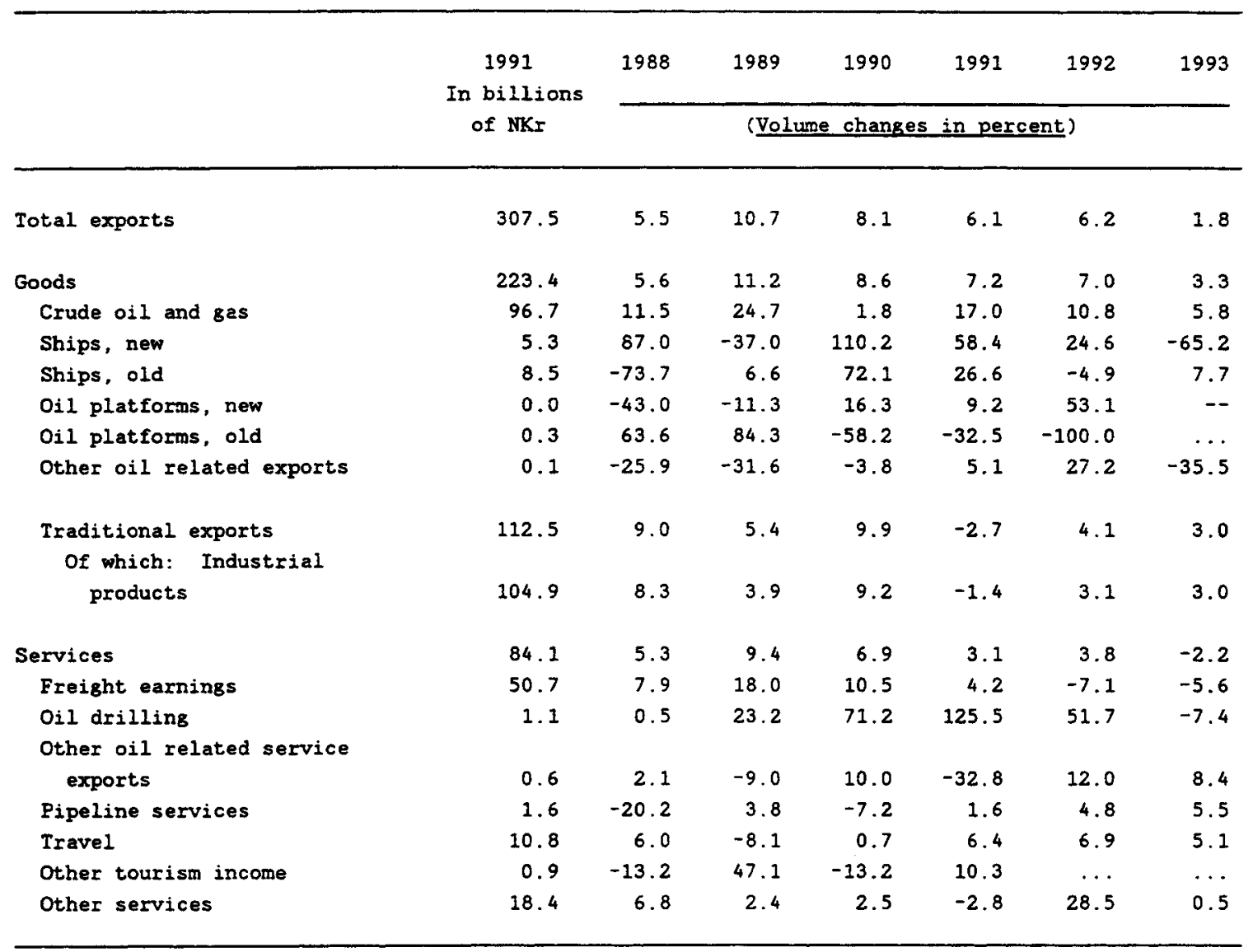

Source: Central Bureau of Statistics, National Accounts Statistics. 
Table A9. Norway: Imports of Goods and Services

\begin{tabular}{|c|c|c|c|c|c|c|c|}
\hline & 1991 & 1988 & 1989 & 1990 & 1991 & 1992 & 1993 \\
\hline & \multirow{2}{*}{$\begin{array}{l}\text { In billions } \\
\text { of } \mathrm{NKS}\end{array}$} & & & & & & \\
\hline & & \multicolumn{6}{|c|}{ (Volume changes in percent) } \\
\hline Total imports & 247.1 & -1.7 & 0.9 & 2.2 & 1.7 & 2.8 & 3.3 \\
\hline Goods & 170.3 & -2.8 & -0.3 & 2.6 & -0.2 & -0.9 & 4.6 \\
\hline Ships, new & 4.5 & -16.9 & 15.8 & -8.9 & 177.4 & $\ldots$ & $\cdots$ \\
\hline Ships, old & 6.3 & 258.2 & 46.4 & -48.4 & -45.6 & $\cdots$ & $\ldots$ \\
\hline Oil platforms, new & 2.1 & -58.1 & -79.2 & 384.4 & 142.3 & $\ldots$ & $\ldots$ \\
\hline Oil platforms, old & 1.0 & $\cdots$ & $\cdots$ & $\cdots$ & $\ldots$ & $\ldots$ & $\ldots$ \\
\hline Other oil related imports & 4.3 & 22.3 & 39.1 & -57.5 & 301.8 & 1.8 & 25.0 \\
\hline Traditional imports & 152.1 & -7.2 & -4.8 & 9.8 & 0.2 & 3.9 & 1.8 \\
\hline Services & 76.8 & 1.1 & 4.0 & 1.1 & 6.6 & 9.0 & 0.8 \\
\hline Shipping & 27.9 & 7.0 & 17.6 & 3.5 & 6.5 & -8.4 & -9.5 \\
\hline Oil drilling & 1.3 & 108.1 & 124.8 & 79.0 & 76.0 & 9.2 & 21.0 \\
\hline \multicolumn{8}{|l|}{ Other oil related service } \\
\hline imports & 7.0 & -41.7 & 58.0 & 5.1 & 78.9 & -1.1 & -5.0 \\
\hline Trave1 & 21.2 & 3.7 & -16.9 & 3.8 & -9.7 & 12.3 & 3.5 \\
\hline Other tourism expenditures & 1.4 & 49.5 & 32.5 & 15.0 & -10.7 & $\cdots$ & $\ldots$ \\
\hline Other services & 18.1 & -3.6 & 4.7 & -9.5 & 10.6 & 39.4 & 10.3 \\
\hline
\end{tabular}

Source: Central Bureau of Statistics, National Accounts Statistics. 
Table A10. Norway: Current Account Balance

\begin{tabular}{|c|c|c|c|c|c|c|c|}
\hline & 1991 & 1988 & 1989 & 1990 & 1991 & 1992 & 1993 \\
\hline & \multirow{2}{*}{$\begin{array}{l}\text { In billions } \\
\text { of } \mathrm{NKr}\end{array}$} & & & & & & \\
\hline & & \multicolumn{6}{|c|}{ (In percent of GDP) } \\
\hline \multicolumn{8}{|l|}{ Goods and services } \\
\hline Exports & 307.5 & 36.6 & 42.1 & 44.3 & 44.8 & 43.2 & 43.3 \\
\hline Goods & 223.4 & 26.2 & 30.6 & 32.5 & 32.5 & 31.3 & 31.1 \\
\hline Services & 84.1 & 10.5 & 11.5 & 11.8 & 12.3 & 11.9 & 12.2 \\
\hline Imports & 247.1 & 37.4 & 37.7 & 36.9 & 36.0 & 35.9 & 36.5 \\
\hline Goods & 170.3 & 26.6 & 26.7 & 26.1 & 24.8 & 23.7 & 24.1 \\
\hline Services & 76.8 & 10.7 & 10.9 & 10.8 & 11.2 & 12.2 & 12.4 \\
\hline Trade balance & 53.1 & -0.5 & 3.9 & 6.4 & 7.8 & 7.6 & 7.0 \\
\hline Services balance & 7.3 & -0.3 & 0.6 & 2.0 & 1.1 & -0.3 & -0.2 \\
\hline Balance of goods and services & 60.4 & -0.7 & 4.5 & 7.4 & 8.8 & 7.3 & 6.8 \\
\hline \multicolumn{8}{|l|}{ Factor payments } \\
\hline From abroad & 25.9 & 4.0 & 4.2 & 4.1 & 3.8 & 3.2 & 3.0 \\
\hline Interest & 20.8 & 3.3 & 3.6 & 3.5 & 3.0 & 2.5 & 2.2 \\
\hline Dividends & 2.8 & 0.4 & 0.3 & 0.4 & 0.4 & 0.3 & 0.3 \\
\hline Transfers & 2.3 & 0.3 & 0.3 & 0.3 & 0.3 & 0.4 & 0.5 \\
\hline To abroad & 53.2 & 7.6 & 8.4 & 8.1 & 7.8 & 79 & 7.4 \\
\hline Interest & 31.7 & 5.1 & 5.8 & 5.4 & 4.6 & 3.6 & 3.4 \\
\hline Dividends & 9.4 & 0.9 & 1.0 & 1.1 & 1.4 & 23 & 2.2 \\
\hline Transfers & 12.1 & 1.6 & 1.5 & 1.6 & 1.8 & $: 9$ & 28 \\
\hline Balance of factor payments & -27.3 & -3.6 & -4.1 & -4.0 & -4.0 & -67 & -65 \\
\hline Current account balance & 33.1 & -4.3 & 0.3 & 3.4 & 4.9 & 25 & 2 \\
\hline
\end{tabular}

Source: Okonomiske analyser, various issues. 
Table A11. Norway: Net External Debt

(In bilizions of NKr)

\begin{tabular}{|c|c|c|c|c|c|c|}
\hline & 1988 & 1989 & 1990 & 1991 & 1992 & 1993 \\
\hline \multicolumn{7}{|l|}{ Net external debt } \\
\hline Private sector & 179.2 & 185.8 & $162 . i$ & 115.6 & 80.9 & 128.2 \\
\hline Oil and shipping & 51.3 & 45.8 & 28.1 & 28.4 & 15.5 & 23.2 \\
\hline Private financial institutions & 95.9 & 102.6 & 102.1 & 43.7 & -19.3 & 5.0 \\
\hline Other & 32.0 & 37.4 & 31.9 & 44.5 & 84.7 & 100.0 \\
\hline Public sector & -34.4 & -39.8 & -50.5 & -43.2 & -15.8 & -70.5 \\
\hline Central government & 13.9 & 15.6 & 13.7 & 22.1 & 50.3 & 66.6 \\
\hline State banks and Norges Bank & -60.1 & -66.4 & -73.1 & -73.8 & -74.1 & -143.7 \\
\hline Local governments & 11.8 & 11.0 & 8.9 & 8.5 & 8.0 & 6.6 \\
\hline Total & 144.8 & 146.0 & 111.6 & 73.4 & 65.1 & 57.7 \\
\hline \multicolumn{7}{|l|}{ Memorandum item: } \\
\hline \multicolumn{7}{|l|}{ Net external debt } \\
\hline (in percent of GDP) & 24.8 & 23.5 & 16.9 & 20.7 & 9.3 & 7.9 \\
\hline
\end{tabular}

Sources: NasjonalBudsjettet, various issues; and Norges Bank, Economic Bulietin. 
Table A12. Norway: Labor Market Indicators

\begin{tabular}{|c|c|c|c|c|c|c|}
\hline & 1988 & 1989 & 1990 & 1991 & 1992 & 1993 \\
\hline & \multicolumn{6}{|c|}{ (Period averages in thousands) } \\
\hline \multicolumn{7}{|l|}{ Survey data } \\
\hline Labor force & 2,183 & 2,154 & 2,142 & 2,126 & 2,130 & 2,131 \\
\hline Employment & 2,114 & 2,049 & 2,030 & 2,010 & 2,004 & 2,004 \\
\hline Unemployment & 70 & 106 & 112 & 116 & 126 & 127 \\
\hline \multicolumn{7}{|l|}{$\begin{array}{l}\text { Data based on information } \\
\text { from employment agencies }\end{array}$} \\
\hline Registered unemployment & 49 & 83 & 93 & 101 & 114 & 118 \\
\hline Unfilled vacancies & 9 & 7 & 7 & 7 & 6 & 7 \\
\hline \multicolumn{7}{|l|}{ Persons affected by } \\
\hline \multirow[t]{2}{*}{ labor market programs } & 19 & 46 & 51 & 57 & 63 & 72 \\
\hline & \multicolumn{6}{|c|}{ (In percent of labor force) } \\
\hline Survey unemployment & 3.2 & 4.9 & 5.2 & 5.5 & 5.9 & 6.0 \\
\hline Registered unemployment & 2.3 & 3.8 & 4.3 & 4.7 & 5.4 & 5.5 \\
\hline Unfilled vacancies & 0.4 & 0.3 & 0.3 & 0.3 & 0.3 & 0.3 \\
\hline \multicolumn{7}{|l|}{ Persons affected by } \\
\hline labor market measures & 0.9 & 2.1 & 2.4 & 2.7 & 2.9 & 3.4 \\
\hline
\end{tabular}

Source: Monthly Bulletin of Statistics. 
Table A13. Norway: Hages and Prices

(Annual percentage changes)

\begin{tabular}{|c|c|c|c|c|c|c|}
\hline & 1988 & 1989 & 1990 & 1991 & 1992 & 1993 \\
\hline \multicolumn{7}{|l|}{ Hourly wage costs } \\
\hline Total economy & 5.8 & 4.5 & 4.9 & 5.2 & 2.8 & 2.7 \\
\hline Mainland & 5.9 & 4.7 & 5.2 & 5.1 & 2.6 & 2.5 \\
\hline Mainland GDP deflator & 7.2 & 3.6 & 2.6 & 3.6 & 1.6 & 1.6 \\
\hline \multicolumn{7}{|l|}{ Manufacturing labor costs } \\
\hline Hourly labor costs & 6.1 & 4.4 & 5.6 & 4.7 & 2.8 & 1.3 \\
\hline Productivity & -0.5 & 5.2 & 2.5 & 0.7 & 1.8 & 2.1 \\
\hline Unit labor costs & 6.6 & -0.8 & 3.0 & 3.9 & 1.0 & -0.8 \\
\hline Consumer prices & 6.2 & 4.3 & 4.8 & 4.1 & 2.6 & 1.9 \\
\hline Food & 6.1 & 2.9 & 3.2 & 1.8 & 1.4 & -1.2 \\
\hline Beverages and tobacco & 6.8 & 5.1 & 6.9 & 7.1 & 9.0 & 3.1 \\
\hline Clothing and footwear & 5.8 & 3.0 & 2.3 & 2.1 & 1.9 & 2.8 \\
\hline Housing, light and fuels & 8.5 & 6.0 & 6.4 & 4.4 & 1.7 & 2.8 \\
\hline Furniture and household appliances & 5.6 & 3.5 & 2.5 & 2.1 & 0.6 & 2.1 \\
\hline Health services & 3.1 & 4.3 & 6.9 & 5.6 & 5.9 & 3.3 \\
\hline \multicolumn{7}{|l|}{ Transportation and } \\
\hline communication services & 6.2 & 5.4 & 3.0 & 2.2 & 2.4 & 2.9 \\
\hline Education and recreation & 4.9 & 3.9 & 4.2 & 3.9 & 2.5 & 3.2 \\
\hline \multicolumn{7}{|l|}{ Other domestic goods } \\
\hline and services & 6.2 & 3.6 & 7.5 & 7.5 & 2.6 & 2.1 \\
\hline \multicolumn{7}{|l|}{ Memorandum item: } \\
\hline Manufacturing unit labor costs & & & & & & \\
\hline in partner countries & -- & 3.0 & 4.6 & 4.4 & 1.9 & 0.6 \\
\hline
\end{tabular}

Source: Okonomiske analyser, various issues. 
TabI0 A14. Horway: Central Government Finances 1/

\begin{tabular}{|c|c|c|c|c|}
\hline & 1991 & 1992 & 1993 & $\begin{array}{l}1994 \\
\text { Pre1. }\end{array}$ \\
\hline & \multicolumn{4}{|c|}{ (In billtons of Homegien kroner) } \\
\hline $\begin{array}{l}\text { Total revenues } \\
\text { Property income }\end{array}$ & $\begin{array}{r}318.3 \\
56.4\end{array}$ & $\begin{array}{r}316.5 \\
53.1\end{array}$ & $\begin{array}{r}326.6 \\
57.5\end{array}$ & $\begin{array}{r}348.4 \\
58.9\end{array}$ \\
\hline Income erom petroloum activities & 14.1 & 13.0 & 17.9 & 18.6 \\
\hline Interest & 8.5 & 9.0 & 9.8 & 10.8 \\
\hline Profits & 5.6 & 3.9 & 8.1 & 7.8 \\
\hline Other property incone & 36.5 & 35.6 & 34.5 & 30.8 \\
\hline Interest & 40.3 & 38.3 & 36.8 & 33.1 \\
\hline Profits & -3.8 & -2.7 & -2.3 & -2.3 \\
\hline Transfors from Norges Bank & 5.7 & $\begin{array}{r}4.5 \\
269\end{array}$ & $\begin{array}{r}5.1 \\
267.6\end{array}$ & $\begin{array}{r}9.5 \\
287.9\end{array}$ \\
\hline Taxes and sociai security contributions & 258.4 & 261.5 & 267.6 & 287.9 \\
\hline \multicolumn{5}{|l|}{ Cther direct texes and social security } \\
\hline contributions & 123.6 & 124.0 & 122.9 & 132.2 \\
\hline Indirect taxes & 102.7 & 112.1 & 118.0 & 130.7 \\
\hline Transfers frcm other government sectors & 3.5 & 1.9 & 1.5 & 1.6 \\
\hline $\begin{array}{l}\text { Total expenditures } \\
\text { Interost }\end{array}$ & $\begin{array}{r}319.2 \\
17.4\end{array}$ & $\begin{array}{r}341.1 \\
18.0\end{array}$ & $\begin{array}{r}362.5 \\
20.4\end{array}$ & $\begin{array}{r}372.9 \\
21.4\end{array}$ \\
\hline Irensfers to private sector and to abroad & 173.0 & 183.9 & 193.5 & 201.6 \\
\hline Iransfers to abroad & 7.6 & 8.1 & 7.8 & 8.4 \\
\hline Subsidies & 37.9 & 39.1 & 43.4 & 48.3 \\
\hline Transfors to consumers & 127.5 & 136.7 & 142.4 & 144.9 \\
\hline \multirow{2}{*}{$\begin{array}{l}\text { Trensfers to other government sectors } \\
\text { Consumption }\end{array}$} & 57.5 & 61.6 & 61.2 & 63.4 \\
\hline & 58.4 & 62.7 & 64.7 & 67.2 \\
\hline Goods and services & 63.0 & 66.7 & 69.0 & 69.7 \\
\hline Deprectation & 1.6 & 1.8 & 1.8 & 2.1 \\
\hline Feos & 6.2 & 5.8 & 6.0 & 4.6 \\
\hline Net investment in government services & 8.6 & 8.9 & 7.7 & 6.1 \\
\hline \multirow{2}{*}{$\begin{array}{l}\text { Net financial investment in business activitios } \\
\text { Petroloum activitfes }\end{array}$} & 4.5 & 6.0 & 15.0 & 13.2 \\
\hline & 6.6 & 8.1 & 16.0 & 17.3 \\
\hline Other & -2.1 & -2.0 & -1.1 & -4.0 \\
\hline Overall balance & -1.0 & -24.6 & -35.9 & -24.5 \\
\hline Overall balence, corrected for petroloum activities & -40.7 & -54.9 & -64.4 & -50.9 \\
\hline $\begin{array}{l}\text { Disposuble income } \underline{2} / \\
\text { Net seving } \underline{3} /\end{array}$ & 70.4 & 53.1 & 51.6 & 62.0 \\
\hline & 12.0 & -9.6 & -13.2 & -5.2 \\
\hline \multirow[t]{2}{*}{ Net financial investrent 4 / } & 3.5 & -18.6 & -20.9 & -11.3 \\
\hline & \multicolumn{4}{|c|}{ (in percent of GDP) } \\
\hline \multirow{2}{*}{$\begin{array}{l}\text { Totai revenues } \\
\text { Petroloum revenues and transfers Erom Horges Bank } \\
\text { Other }\end{array}$} & 46.3 & 45.0 & 44.5 & 45.6 \\
\hline & $\begin{array}{r}7.6 \\
38.8\end{array}$ & $\begin{array}{r}6.1 \\
38.9\end{array}$ & $\begin{array}{r}6.8 \\
37.7\end{array}$ & $\begin{array}{r}6.9 \\
38.6\end{array}$ \\
\hline \multirow{3}{*}{$\begin{array}{l}\text { Total expenditures } \\
\text { Patroleum expenditures } \\
\text { Other }\end{array}$} & 46.5 & 48.5 & 49.4 & 48.7 \\
\hline & 1.0 & 1.2 & 2.2 & 2.3 \\
\hline & 45.5 & 47.3 & 47.7 & 46.4 \\
\hline \multirow{3}{*}{$\begin{array}{l}\text { Cverall balance } \\
\text { Petroieum items including transfers from Norges Bank } \\
\text { Other }\end{array}$} & -0.1 & -3.5 & -4.9 & -3.2 \\
\hline & 6.6 & 4.9 & 4.6 & 4.7 \\
\hline & -6.7 & -8.4 & -9.5 & -7.9 \\
\hline Net financial investment 4 / & 0.5 & -2.6 & -2.8 & -1.5 \\
\hline
\end{tabular}

Sourco: Nasjorabudjettst 1995.

1/ On a cash basis, including social security and non-budgetary funds.

2/ Total revenues less expenditures on interest and transfers.

3/ Disposable incomes less consumption expenditures.

4/ Net saving less net real investment. 
Table A15. Norway: Local Government Finances 1/

\begin{tabular}{|c|c|c|c|c|}
\hline & 1991 & 1992 & 1993 & $\begin{array}{l}1994 \\
\text { Prel }\end{array}$ \\
\hline & \multicolumn{4}{|c|}{ (In billions of Norwegian kroner) } \\
\hline $\begin{array}{l}\text { Total revenues } \\
\text { Property income } \\
\text { Interest } \\
\text { Profits } \\
\text { Taxes } \\
\text { Direct taxes } \\
\text { Indirect taxes } \\
\text { Transfers from other } \\
\text { government sectors }\end{array}$ & $\begin{array}{r}125.7 \\
2.3 \\
2.9 \\
-0.7 \\
66.0 \\
63.3 \\
2.7 \\
57.5\end{array}$ & $\begin{array}{r}131.9 \\
2.9 \\
3.1 \\
-0.2 \\
67.3 \\
64.2 \\
3.0 \\
61.6\end{array}$ & $\begin{array}{r}134.1 \\
2.6 \\
2.8 \\
-0.2 \\
70.3 \\
67.1 \\
3.2\end{array}$ & $\begin{array}{r}141.0 \\
2.0 \\
2.0 \\
-0.3 \\
75.9 \\
72.6 \\
3.3 \\
63.4\end{array}$ \\
\hline $\begin{array}{l}\text { Total expenditures } \\
\text { Interest } \\
\text { Transfers to private sector } \\
\text { Subsidies } \\
\text { Transfers to consumers } \\
\text { Transfers to other }\end{array}$ & $\begin{array}{r}127.0 \\
7.5 \\
18.3 \\
4.9 \\
13.4\end{array}$ & $\begin{array}{r}132.0 \\
7.7 \\
19.3 \\
5.3 \\
14.0\end{array}$ & $\begin{array}{r}133.9 \\
7.4 \\
20.2 \\
5.7 \\
14.4\end{array}$ & $\begin{array}{r}138.6 \\
5.8 \\
20.7 \\
5.8 \\
14.9\end{array}$ \\
\hline $\begin{array}{l}\text { government sectors } \\
\text { Consumption } \\
\text { Goods and services } \\
\text { Depreciation } \\
\text { Fees } \\
\text { Net investment in real assets }\end{array}$ & $\begin{array}{r}3.5 \\
89.1 \\
100.0 \\
4.6 \\
15.5 \\
8.6\end{array}$ & $\begin{array}{r}1.9 \\
94.6 \\
106.585 \\
4.8 \\
16.9 \\
8.6\end{array}$ & $\begin{array}{r}1.5 \\
87.1 \\
110.1 \\
4.9 \\
18.0 \\
7.7\end{array}$ & $\begin{array}{r}1.6 \\
103.0 \\
116.3 \\
5.4 \\
18.7 \\
7.5\end{array}$ \\
\hline Overall balance & -1.3 & -0.2 & 0.2 & 2.4 \\
\hline $\begin{array}{l}\text { Disposable income } 2 / \\
\text { Net saving } 3\end{array}$ & $\begin{array}{r}96.5 \\
7.4\end{array}$ & $\begin{array}{r}103.0 \\
8.4\end{array}$ & $\begin{array}{r}105.0 \\
7.9\end{array}$ & $\begin{array}{r}113.0 \\
10.0\end{array}$ \\
\hline \multirow[t]{2}{*}{ Net financial investment 4} & -1.3 & -0.2 & 0.2 & 2.4 \\
\hline & \multicolumn{4}{|c|}{ (In percent of GDP) } \\
\hline $\begin{array}{l}\text { Total revenues } \\
\text { Total expenditures }\end{array}$ & $\begin{array}{l}18.3 \\
18.5\end{array}$ & $\begin{array}{l}18.8 \\
18.8\end{array}$ & $\begin{array}{l}18.3 \\
18.3\end{array}$ & $\begin{array}{l}18.4 \\
18.1\end{array}$ \\
\hline Overall balance & -0.2 & 0.0 & 0.0 & 0.3 \\
\hline Net financial investment 4 & -0.2 & 0.0 & 0.0 & 0.3 \\
\hline
\end{tabular}

Source: Nasjonalbudjettet 1995.

1) On a cash basis.

2/ Total revenues less expenditures on interest and transfers.

3) Disposable incomes less consumption expenditures.

4) Net saving less net real investment. 
Table A16. Horway: General Government Finances 1/

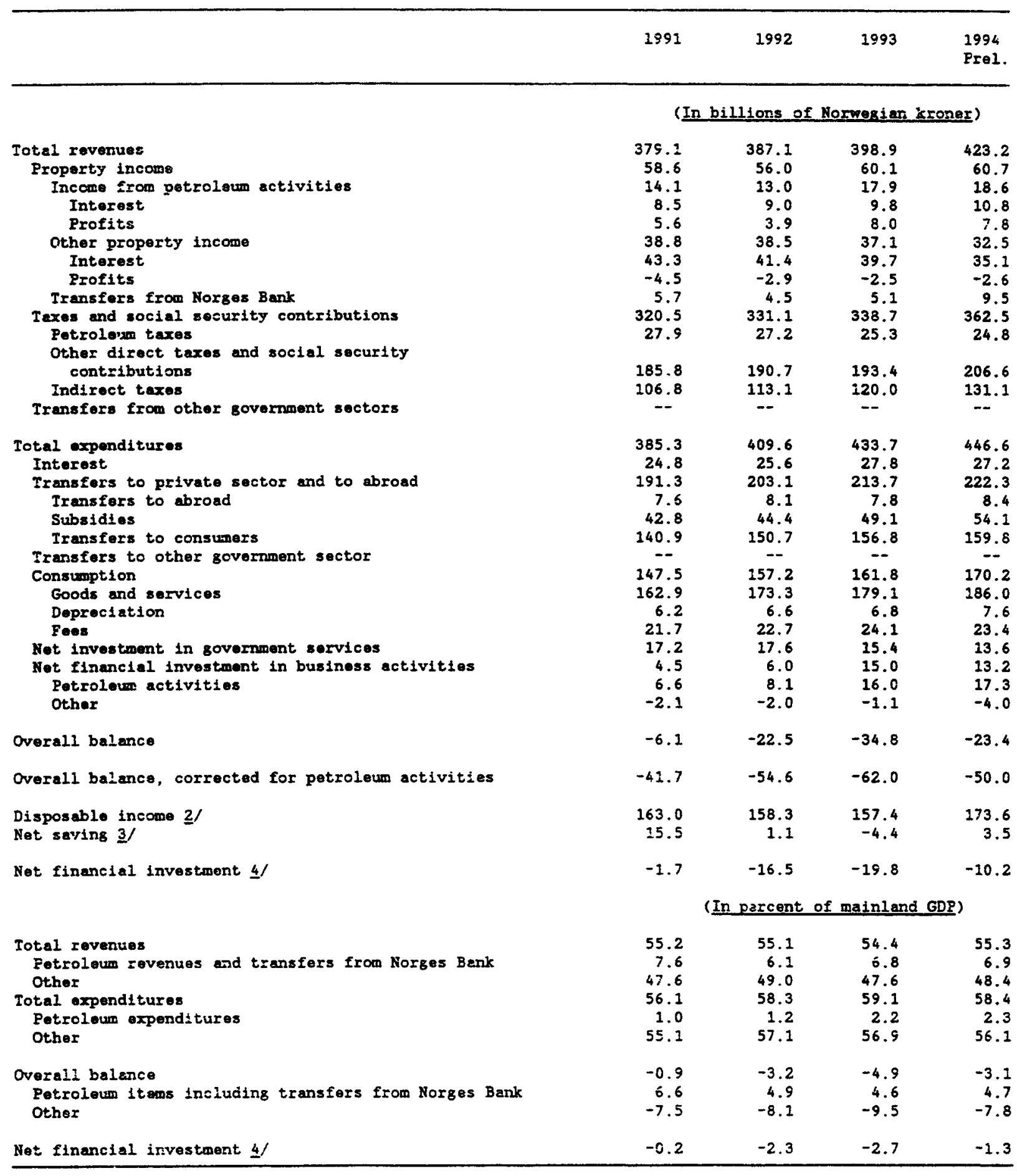

Source: Nasjonabuidjettet 1995.

1) On a national accounts basis.

$\frac{1}{2}$ Total revenuos less expenditures on interest and transfers.

3/ Disposable incomes less consunption expenditures.

4f Net saving less net roei investment. 
Table A17. Norway: Interest Rates

\begin{tabular}{|c|c|c|c|c|c|c|c|c|c|c|c|}
\hline & \multicolumn{3}{|c|}{ Discount rates $1 /$} & \multicolumn{3}{|c|}{ 3-month Interbank rates $2 /$} & \multicolumn{3}{|c|}{ Government bond yields $2 /$} & \multirow{2}{*}{\multicolumn{2}{|c|}{$\frac{\text { Stock market indice }}{(1990=100)}$}} \\
\hline & \multirow[t]{2}{*}{ Norway } & \multirow{2}{*}{ Germany } & \multirow{2}{*}{$\begin{array}{l}\text { Differ- } \\
\text { ential }\end{array}$} & \multirow[t]{2}{*}{ Norway } & \multirow[t]{2}{*}{ Germany } & \multirow{2}{*}{$\begin{array}{l}\text { Differ- } \\
\text { ential }\end{array}$} & \multirow[t]{2}{*}{ Norway } & \multirow[t]{2}{*}{ Germany } & \multirow{2}{*}{$\begin{array}{l}\text { Differ- } \\
\text { ential }\end{array}$} & & \\
\hline & & & & & & & & & & Norway & Germany \\
\hline 1987 & 13.8 & 2.5 & 11.3 & 14.7 & 4.0 & 10.7 & 13.6 & 6.3 & 7.2 & 57.5 & 81.7 \\
\hline 1988 & 12.0 & 3.5 & 8.5 & 13.5 & 4.3 & 9.2 & 13.0 & 6.6 & 6.4 & 50.5 & 68.3 \\
\hline 1989 & 11.0 & 6.0 & 5.0 & 11.4 & 7.1 & 4.3 & 11.0 & 7.1 & 3.9 & 80.7 & 87.3 \\
\hline 1990 & 10.5 & 6.0 & 4.5 & 11.5 & 8.4 & 3.1 & 10.7 & 8.9 & 1.9 & 100.0 & 100.0 \\
\hline 1991 & 10.0 & 8.0 & 2.0 & 10.6 & 9.2 & 1.4 & 9.9 & 8.5 & 1.3 & 93.1 & 89.1 \\
\hline 1992 & 11.0 & 8.2 & 2.8 & 11.8 & 9.5 & 2.4 & 9.8 & 7.8 & 2.0 & 86.7 & 86.2 \\
\hline 1993 & 7.0 & 5.8 & 1.2 & 7.3 & 7.2 & 0.0 & 6.5 & 6.5 & 0.1 & 111.4 & 87.8 \\
\hline \multicolumn{12}{|l|}{1992} \\
\hline Jan. & 10.0 & 8.0 & 2.0 & 10.6 & 9.5 & 1.1 & 9.4 & 7.9 & 1.4 & 93.6 & 88.6 \\
\hline Feb. & 10.0 & 8.0 & 2.0 & 10.5 & 9.5 & 1.0 & 9.4 & 7.9 & 1.5 & 88.7 & 91.9 \\
\hline Mar. & 10.0 & $8.0^{\circ}$ & 2.0 & 10.4 & 9.7 & 0.7 & 9.5 & 7.9 & 1.6 & 90.2 & 93.3 \\
\hline Apr. & 10.0 & 8.0 & 2.0 & 10.3 & 9.7 & 0.6 & 9.5 & 7.9 & 1.6 & 91.8 & 94.1 \\
\hline May & 10.0 & 8.0 & 2.0 & 10.4 & 9.7 & 0.7 & 9.5 & 8.0 & 1.5 & 99.2 & 94.9 \\
\hline Jume & 10.0 & 8.0 & 2.0 & 10.4 & 9.7 & 0.7 & 9.6 & 8.0 & 1.7 & 95.3 & 94.5 \\
\hline July & 10.0 & 8.8 & 1.2 & 10.5 & 9.7 & 0.8 & 10.0 & 8.0 & 1.9 & 87.9 & 88.9 \\
\hline Aus. & 10.0 & 8.8 & 1.2 & 11.1 & 9.8 & 1.3 & 10.3 & 8.0 & 2.3 & 80.4 & 82.1 \\
\hline Sep. & 11.0 & 8.2 & 2.8 & 15.1 & 9.4 & 5.7 & 10.8 & 7.6 & 3.1 & 73.5 & 80.2 \\
\hline Oct. & 11.0 & 8.2 & 2.8 & 12.5 & 8.9 & 3.6 & 9.9 & 7.4 & 2.6 & 75.1 & 74.9 \\
\hline Nov. & 11.0 & 8.2 & 2.8 & 14.6 & 8.9 & 5.7 & 10.2 & 7.4 & 2.8 & 77.4 & 75.8 \\
\hline Dec. & 11.0 & 8.2 & 2.8 & 15.4 & 9.0 & 6.4 & 9.3 & 7.4 & 2.0 & 86.9 & 75.7 \\
\hline \multicolumn{12}{|l|}{1993} \\
\hline Jan. & 10.0 & 8.2 & 1.8 & 10.6 & 8.5 & 2.1 & 8.8 & 7.1 & 1.7 & 88.3 & 78.1 \\
\hline Feb. & 9.2 & 8.0 & 1.2 & 9.3 & 8.3 & 1.0 & 8.0 & 7.0 & 1.0 & 93.2 & 82.1 \\
\hline Mar. & 8.8 & 7.5 & 1.2 & 8.8 & 7.9 & 0.9 & 7.5 & 6.6 & 0.9 & 101.2 & 83.5 \\
\hline Apr. & 7.8 & 7.2 & 0.5 & 8.3 & 7.8 & 0.5 & 7.0 & 6.6 & 0.4 & 101.8 & 82.5 \\
\hline May & 7.5 & 7.2 & 0.2 & 7.3 & 7.4 & -0.1 & 6.8 & 6.8 & -0.0 & 105.4 & 80.5 \\
\hline June & 7.5 & 7.2 & 0.2 & 6.8 & 7.6 & -0.7 & 6.2 & 6.8 & -0.5 & 102.0 & 82.5 \\
\hline July & 7.5 & 6.8 & 0.8 & 6.5 & 7.2 & -0.7 & 6.2 & 6.6 & -0.3 & 110.8 & 87.6 \\
\hline Aug. & 7.5 & 6.8 & 0.8 & 6.0 & 6.6 & -0.6 & 5.8 & 6.3 & -0.5 & 126.1 & 91.5 \\
\hline Sep. & 7.5 & 6.2 & 1.2 & 6.3 & 6.6 & -0.2 & 5.9 & 6.1 & -0.3 & 118.3 & 90.8 \\
\hline Oct. & 7.0 & 5.8 & 1.2 & 6.2 & 6.6 & -0.4 & 5.4 & 5.9 & -0.5 & 127.8 & 95.0 \\
\hline Nov. & 6.8 & 5.8 & 1.0 & 5.4 & 6.3 & -0.8 & 5.3 & 5.9 & & 130.8 & 97.2 \\
\hline Dec. & 7.0 & 5.8 & 1.2 & 5.6 & 6.1 & -0.5 & 5.2 & 5.7 & -65 & $: 32.8$ & 102.1 \\
\hline \multicolumn{12}{|l|}{1994} \\
\hline Jan. & 7.0 & 5.8 & 1.2 & 5.4 & 5.8 & -0.5 & 5.0 & 5.6 & $\because t \quad t$ & $: 4: 1$ & 105.2 \\
\hline Feb. & 7.0 & 5.2 & 1.8 & 5.1 & 5.9 & -0.8 & 5.1 & 5.9 & $-c \varepsilon$ & :56 2 & 104.8 \\
\hline Mar. & 6.8 & 5.2 & 1.5 & 5.2 & 5.8 & -0.5 & 6.0 & 6.3 & $\because \vdots$ & 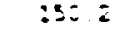 & 106.9 \\
\hline Apr. & 6.8 & 5.0 & 1.8 & 5.5 & 5.5 & -0.1 & 6.3 & 6.4 & $\because 1$ & ins = & 111.6 \\
\hline May & 6.8 & 4.5 & 2.2 & 5.1 & 5.1 & 0.0 & 7.4 & 6.6 & $=E$ & $24:=$ & 112.4 \\
\hline June & 6.8 & 4.5 & 2.2 & 5.4 & 5.0 & 0.4 & 7.8 & 7.1 & $=\quad ;$ & $: 346$ & 104.9 \\
\hline July & 6.8 & 4.5 & 2.2 & 5.5 & 4.9 & 0.6 & 7.4 & 6.9 & $\therefore$ & $: 30 \varepsilon$ & 104.6 \\
\hline Aug. & 6.8 & 4.5 & 2.2 & 5.9 & 5.0 & 0.9 & 7.9 & 7.1 & $\therefore \leq$ & ios = & 109.5 \\
\hline Sep. & 6.8 & 4.5 & 2.2 & 6.7 & 5.0 & 1.7 & 8.7 & 7.5 & : : & :3E $\leq$ & 106.8 \\
\hline Oct. & 6.8 & 4.5 & 2.2 & 6.9 & 5.2 & 1.7 & 8.4 & 7.6 & $:$ & $: 3 i z$ & 101.7 \\
\hline Nov. & 6.8 & 4.5 & 2.2 & 7.2 & 5.2 & 2.0 & 8.6 & 7.5 & : : & $: 335$ & 101.9 \\
\hline Dec. & $\ldots$ & 4.5 & $\ldots$ & 6.1 & 5.3 & 0.8 & 8.1 & 7.3 & : ? & & $\ldots$ \\
\hline
\end{tabular}

Source: IMF, International Financial Statistics.

1/ End of period.

2/ Period averages. 
Table A18. Norway: Exchange Rate Developments

\begin{tabular}{|c|c|c|c|c|c|c|c|c|c|c|}
\hline & \multirow[t]{2}{*}{$\begin{array}{l}\text { Krone/ } \\
\text { SDR }\end{array}$} & \multirow[t]{2}{*}{$\begin{array}{c}\text { Krone/ } \\
\text { USS }\end{array}$} & \multirow[t]{2}{*}{$\begin{array}{c}\text { Krone/ } \\
\text { ECU }\end{array}$} & \multicolumn{2}{|c|}{$\begin{array}{l}\text { Effective exchange } \\
\text { rates }(1990=100)\end{array}$} & \multirow[t]{2}{*}{$\begin{array}{r}\text { SDR/ } \\
\text { Krone }\end{array}$} & \multirow[t]{2}{*}{$\begin{array}{l}\text { USS/ } \\
\text { Krone }\end{array}$} & \multirow[t]{2}{*}{$\begin{array}{l}\text { ECU/ } \\
\text { Krone }\end{array}$} & \multicolumn{2}{|c|}{$\begin{array}{l}\text { Effective exchange } \\
\text { rates }(1990=100)\end{array}$} \\
\hline & & & & Nominal & Real $1 /$ & & & & Nominal & Real 1/ \\
\hline & \multicolumn{5}{|c|}{ (Period average) } & \multicolumn{5}{|c|}{ (Percent change from previous period) } \\
\hline 1987 & 8.7 & 6.7 & 7.8 & 100.7 & 101.4 & 0.4 & -8.9 & 7.1 & -4.0 & 4.2 \\
\hline 1988 & 8.8 & 6.5 & 7.7 & 100.6 & 103.2 & 0.5 & -3.3 & -0.8 & -0.1 & 1.8 \\
\hline 1989 & 8.9 & 6.9 & 7.6 & 100.7 & 100.8 & 1.0 & 5.9 & -1.3 & 0.1 & -2.3 \\
\hline 1990 & 8.5 & 6.3 & 8.0 & 100.0 & 100.0 & -4.0 & -9.3 & 4.5 & -0.7 & -0.8 \\
\hline 1991 & 8.9 & 6.5 & 8.0 & 98.4 & 97.6 & 4.4 & 3.6 & 0.9 & -1.6 & -2.4 \\
\hline 1992 & 8.8 & 6.2 & 8.0 & 99.4 & 98.0 & -1.3 & -4.1 & 0.3 & 1.1 & 0.4 \\
\hline 1993 & 9.9 & 7.1 & 8.4 & 98.1 & 95.9 & 13.2 & 14.2 & 3.9 & -1.4 & -2.2 \\
\hline \multicolumn{11}{|l|}{1993} \\
\hline Jan. & 9.5 & 6.9 & 8.3 & 98.3 & 95.9 & 2.0 & 2.9 & 0.7 & -0.3 & -0.7 \\
\hline Feb. & 9.6 & 7.0 & 8.3 & 99.4 & 96.6 & 1.1 & 1.5 & -0.9 & 1.0 & 0.7 \\
\hline Mar. & 9.7 & 7.0 & 8.3 & 99.5 & 97.0 & 1.0 & 0.3 & -0.1 & 0.2 & 0.5 \\
\hline Apr. & 9.6 & 6.8 & 8.3 & 99.5 & 97.4 & -1.2 & -3.4 & 0.1 & -0.0 & 0.4 \\
\hline May & 9.6 & 6.8 & 8.3 & 98.7 & 96.9 & 0.6 & 0.4 & 0.1 & -0.8 & -0.5 \\
\hline June & 9.8 & 7.0 & 8.3 & 97.8 & 95.9 & 2.3 & 2.8 & -0.0 & -0.9 & -1.1 \\
\hline July & 10.2 & 7.3 & 8.3 & 97.0 & 94.8 & 3.2 & 4.7 & 0.5 & -0.8 & -1.1 \\
\hline Aug. & 10.3 & 7.4 & 8.3 & 96.6 & 94.4 & 1.6 & 0.8 & 0.3 & -0.4 & -0.5 \\
\hline Sep. & 10.0 & 7.1 & 8.3 & 98.1 & 95.9 & -2.7 & -3.8 & 0.0 & 1.5 & 1.7 \\
\hline Oct. & 10.1 & 7.2 & 8.8 & 97.7 & 95.7 & 0.4 & 1.2 & 6.0 & -0.4 & -0.2 \\
\hline Nov. & 10.3 & 7.4 & 8.3 & 97.0 & 95.2 & 1.8 & 3.2 & -5.6 & -0.7 & -0.5 \\
\hline Dec. & 10.3 & 7.4 & 8.4 & 96.9 & 95.3 & 0.0 & 0.4 & 0.4 & -0.2 & 0.1 \\
\hline \multicolumn{11}{|l|}{1994} \\
\hline Jan. & 10.3 & 7.5 & 8.4 & 95.9 & 94.7 & 0.1 & 0.9 & -0.2 & -1.0 & -0.6 \\
\hline Feb. & 10.4 & 7.5 & 8.4 & 95.4 & 94.5 & 1.2 & 0.1 & -- & -0.5 & -0.2 \\
\hline Mar. & 10.3 & 7.3 & 8.4 & 95.9 & 94.9 & -0.9 & -1.9 & 0.2 & 0.5 & 0.4 \\
\hline Apr. & 10.3 & 7.4 & 8.4 & 95.7 & 94.5 & 0.4 & 0.2 & 0.1 & -0.2 & -0.4 \\
\hline May & 10.2 & 7.2 & 8.4 & 96.4 & 95.2 & -1.7 & -2.5 & -0.2 & 0.8 & 0.7 \\
\hline June & 10.1 & 7.1 & 8.4 & 97.0 & 96.1 & -0.6 & -1.5 & 0.1 & 0.6 & 3.0 \\
\hline July & 10.0 & 6.9 & 8.4 & 97.7 & 97.0 & -1.0 & -3.0 & 0.2 & 0.7 & 0.9 \\
\hline Aug. & 10.0 & 6.9 & 8.4 & 97.6 & 97.3 & -0.3 & -0.1 & 0.1 & -0.0 & 0.2 \\
\hline Sep. & 10.0 & 6.8 & 8.4 & 97.1 & 97.3 & -0.2 & -0.9 & 0.1 & -0.5 & 0.1 \\
\hline Oct. & 9.8 & 6.6 & 8.3 & 97.6 & 98.3 & -1.8 & -2.7 & -0.7 & 0.4 & 1.0 \\
\hline Nov. & 9.9 & 6.7 & 8.4 & 97.1 & 98.4 & 1.2 & 1.6 & 0.3 & -0.5 & 0.1 \\
\hline Dec. & 9.8 & 6.7 & 8.4 & 97.2 & 99.0 & -1.3 & -- & -- & 0.1 & 0.7 \\
\hline
\end{tabular}

Source: IMF, International Financial Statistics.

1/ Normalized unit labor costs in manufacturing adjusted for exchange rate changes 
Table A19. Norway: International Reserves

(In billions of $\mathrm{MKr}$, end of period)

\begin{tabular}{|c|c|c|c|c|c|c|c|}
\hline & 1988 & 1989 & 1990 & 1991 & 1992 & 1993 & 1994 \\
\hline Official reserves & 87.5 & 91.5 & 90.9 & 79.4 & 83.1 & 147.9 & 129.1 \\
\hline Gold I/ & 0.3 & 0.3 & 0.3 & 0.3 & 0.3 & 0.3 & 0.3 \\
\hline SDRs & 3.2 & 3.0 & 2.7 & 2.7 & 1.3 & 3.0 & 2.6 \\
\hline Reserve position in the Fund & 4.0 & 3.8 & 3.4 & 3.4 & 4.5 & 4.4 & 4.4 \\
\hline Foreign exchange & 80.0 & 84.3 & 84.5 & 72.9 & 76.9 & 140.1 & 121.7 \\
\hline \multicolumn{8}{|l|}{ Memorandum item: } \\
\hline \multicolumn{8}{|l|}{ Gross official reserve (IFS) } \\
\hline (in millions SDRs) & 9,901 & 10,531 & 10,819 & 9,292 & 8,725 & 14,327 & 13,074 \\
\hline \multicolumn{8}{|l|}{ (in weeks of merchandise } \\
\hline imports) & 29 & 29 & 28 & 24 & 26 & 44 & \\
\hline
\end{tabular}

Source: IM, International Financial Statistics.

1/ Gold valued at SDR 35 per fine ounce. 